
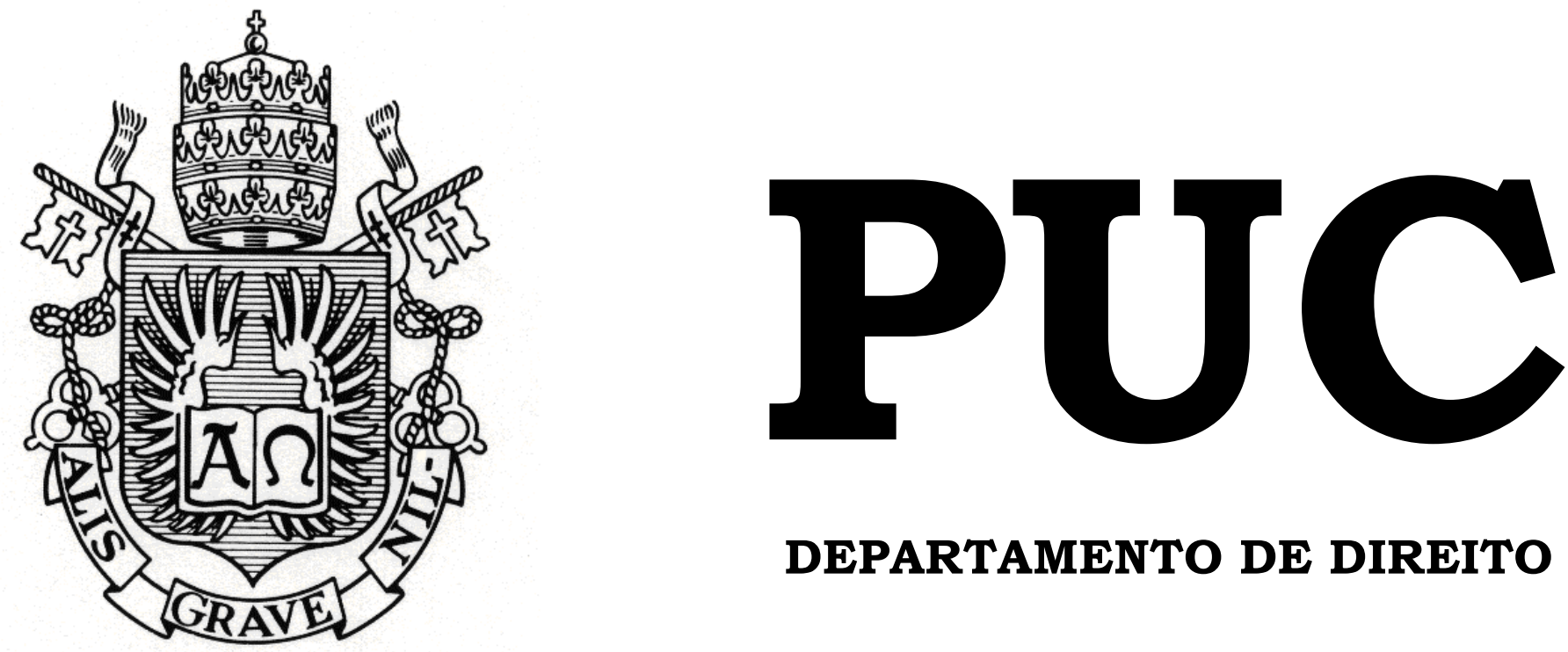

DEPARTAMENTO DE DIREITO

Opressão de gênero: a ausência de um olhar interseccional na busca de soluções juridicas

por

Amanda Martinho Resende

Orientadora: Thula Rafaela de Oliveira Pires

2017.1

PONTIFÍCIA UNIVERSIDADE CATÓLICA DO RIO DE JANEIRO

RUA MARQUÊS DE SÃO VICENTE, 225 - CEP 22453-900

RIO DE JANEIRO - BRASIL 


\title{
Opressão de gênero: a ausência de um olhar interseccional na busca de soluções jurídicas
}

\author{
por \\ Amanda Martinho Resende
}

Monografia apresentada ao Departamento de Direito da Pontifícia Universidade Católica do Rio de Janeiro (PUC-Rio) como requisito parcial para obtenção do Titulo de Bacharel em Direito.

Orientadora: Thula Rafaela de Oliveira Pires. 


\section{Resumo}

Este trabalho propõe uma revisão das estratégias utilizadas pelo Direito em seus esforços para responder às diversas desigualdades sociais e, em especial, à desigualdade de gênero. Para tanto, destaca a importância de uma análise interseccional das posições ocupadas pelos sujeitos em uma sociedade hierarquizada, ou seja, enfatiza a necessidade de se levar em conta as complexas imbricações entre os múltiplos sistemas de opressão que constituem esses sujeitos, delimitam seus espaços e organizam as relações de poder. $\mathrm{O}$ desenvolvimento da aludida abordagem interseccional é informado pelos feminismos pós-estruturalista e decolonial, já que, ao se aproximar do primeiro, este trabalho se torna capaz de oferecer respostas para a construção social e discursiva dos sujeitos, que internalizam e expressam em seus corpos por meio de performances - as categorias identitárias fabricadas por incontáveis discursos marcados pelo gênero, pela raça, pela sexualidade, etc., isto é, marcados por dicotomias hierárquicas; e, ao se nutrir do segundo, elabora uma percepção mais acurada da formação histórica de uma matriz colonial de poder que reúne, articula, produz e é produzida pelas diferentes estruturas de dominação - por raça, classe, gênero, sexualidade -, e que se reatualiza constantemente para se adaptar às novas exigências do capitalismo global. Por fim, este trabalho examina as limitações do tratamento jurídico dado à violência contra a mulher, a partir de uma perspectiva interseccional.

Palavras-chave: interseccionalidade, pós-estruturalismo, decolonialidade, gênero, raça, classe, sexualidade, violência doméstica e familiar. 


\section{Sumário}

Introdução

1. O processo de formação dos sujeitos e os mecanismos de produção das

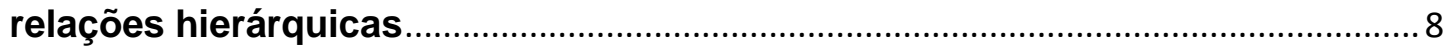

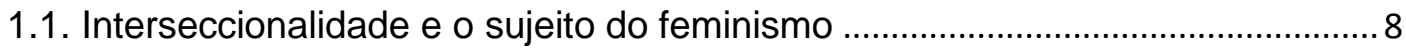

1.2. A construção social e linguística dos sujeitos ................................................ 15

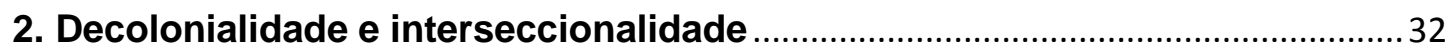

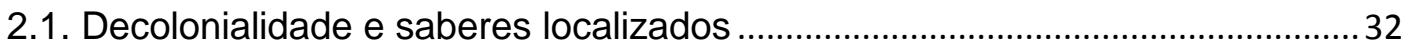

2.2. Gênero, sexualidade, raça e classe no contexto brasileiro: repensando o conceito de interseccionalidade a partir de uma perspectiva decolonial.................47

3. A violência doméstica e familiar contra a mulher e a ausência de um olhar interseccional na busca de soluções jurídicas .........................................................68

3.1. Contextualizando a violência doméstica e familiar contra as mulheres negras

3.2. A Lei Maria da Penha, o crime de feminicídio e suas limitações ....................... 81

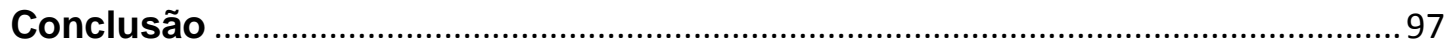

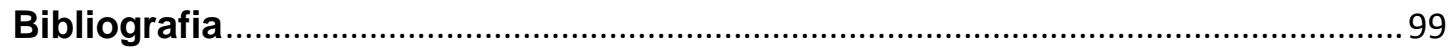




\section{Introdução}

Por honestidade intelectual comigo mesma e com os(as) leitores(as), assim como por um respeito à metodologia e epistemologia feminista de Donna Haraway ${ }^{1}$, me sinto impelida a escrever esta introdução em primeira pessoa, para que eu possa explicitar meu posicionamento específico na sociedade brasileira, uma vez que, é a partir deste lugar particularizado e corporificado que eu enxergo e compreendo o mundo à minha volta e, com isso, produzo conhecimento: sou uma mulher branca de classe alta.

Hoje, durante uma conversa a respeito da entrega da monografia, uma amiga me perguntou se, na introdução, eu escreveria sobre minha metodologia e justificativa para fazer o trabalho. Sem nem pensar duas vezes, respondi que não. Para ser sincera, até aquela ocasião, nem mesmo considerava que possuía uma metodologia, pois tudo que vinha à minha cabeça sobre o assunto se resumia ao clássico: o presente trabalho será baseado na leitura de textos acadêmicos e na análise de estatísticas e dados (...). Quanto à justificativa, sabia o que me motivava, mas não imaginava que poderia ou deveria expor minhas razões pessoais em um trabalho acadêmico.

Neste momento, não consigo desprender meus pensamentos da pergunta de minha amiga, que não me parece mais tão fácil de ser respondida. Embora eu viesse planejando, há algum tempo, falar de minha(s) branquitude(s) e feminilidade(s) nesta introdução, não interpretava esta necessidade como uma metodologia. No entanto, quanto mais reflito sobre o assunto, mais ele me parece evidente. Por certo, eu penso e produzo conhecimento a partir de meu olhar localizado enquanto mulher cisgênero, branca e de classe alta, e dependo metodologicamente da consciência da particularidade de minha posição para

\footnotetext{
${ }^{1}$ HARAWAY, Donna. Saberes localizados: a questão da ciência para o feminismo e o privilégio da perspectiva parcial. Cadernos Pagu, Campinas, n. 5, p. 7-41, jan. 2009.
} 
me manter aberta e para aprender com os múltiplos diálogos e conhecimentos produzidos com base em experiências que desconheço, seja em razão de minha opressão, seja em razão de meus privilégios.

Por outro lado, entendo que todas essas características não me definem, nem limitam quem eu sou e quem eu posso vir a ser, pois minha subjetividade múltipla, contraditória e em processo - constantemente inacabado - vai muito além dessas categorias genéricas. A dificuldade, porém, reside nos obstáculos que me são impostos pelas normas do sistema binário heterossexual de gênero, que, por meio de discursos marcados pelo gênero e de representações estereotipadas de mulheres e homens, limitam meu espaço e me colocam numa posição subordinada e discriminada em relação aos homens. E é nesta oportunidade que começo a enunciar minha justificativa. Pois a diferença entre mim e muitas mulheres está no fato de que eu posso contar com minha condição racial e de classe para facilitar minha luta contra a desigualdade de gênero. Será? Estarei eu lutando contra a desigualdade por meio do usufruto de meus privilégios? Estarei combatendo a desigualdade de quem? Em detrimento dos direitos de quem? Essas perguntas são retóricas por um motivo óbvio: meus privilégios oprimem e meu feminismo não significa nada se eu não buscar a emancipação de todas as mulheres - e de todos os homens -, mulheres oprimidas simultânea e articuladamente por diversas estruturas de dominação que produzem, de forma indissociável, as hierarquias de gênero, raça, classe, orientação sexual, etc., aprisionando estas vidas de tantas maneiras quantas forem possíveis - mas não sem resistência.

Em meio a estas reflexões, me vem à mente uma lembrança acolhedora. Ao fim de uma das aulas de Relações Raciais em Perspectiva Diaspórica, matéria ministrada pelas professoras Thula Pires e Andréa Gill, a primeira, durante uma "reprimenda educativa" dirigida à turma, nos incentivou a formularmos perguntas potentes. $\mathrm{Na}$ aula seguinte, as professoras trouxeram um exemplo para nos inspirar: na última página de seu livro “Ain’t I a Woman: 
Black Women and Feminism", bell hooks questiona: "a pergunta que devemos nos fazer de novo e de novo é como mulheres racistas podem se chamar de feministas" ${ }^{2}$. Esta pergunta se encaixa perfeitamente nas ideias que venho tentando exprimir ao longo desta breve introdução. Eu, uma mulher branca de classe alta, preciso do feminismo. E preciso não só porque ele me fortalece na luta contra a opressão do machismo e do patriarcado. Dependo fundamentalmente do feminismo sobretudo porque ele é o caminho que encontrei, dos muitos possíveis, para enxergar com um pouco mais de clareza minha posição - ou minhas posições - e as diferentes posições ocupadas por muitos(as) outros(as) neste mundo complexo e hierarquizado. Assim, é através desta perspectiva inclusiva, que reconhece a pluralidade e a desigualdade dos modos de se viver e experimentar a realidade, que se torna possível desenvolver estratégias e ações políticas e jurídicas efetivamente capazes de desestabilizar e desarticular as diversas estruturas de poder que organizam nossa sociedade.

Para atingir tal objetivo, isto é, o de evidenciar a interação entre aquelas estruturas - ou será uma única estrutura complexa e multidimensional? Apesar de eu não defender explicitamente esta hipótese durante o trabalho, não descarto a possibilidade -, bem como sua relevância para a formulação de respostas jurídicas efetivas, dividi este trabalho em três momentos distintos. $\mathrm{O}$ primeiro capítulo foi estruturado com base em dois argumentos principais, que estão conectados: para que não se promovam exclusões e silenciamentos, é fundamental que se reconheça a heterogeneidade da categoria mulher. Esta diversidade, por sua vez, decorre da construção social e linguística dos sujeitos, que são formados pelos mais numerosos discursos, símbolos e práticas regulatórias que limitam seus comportamentos e os espaços que ocupam. Minha preocupação inicial, portanto, foi com a desnaturalização das

\footnotetext{
${ }^{2}$ Tradução nossa: "The question we must ask again and again is how can racist women call themselves feminists". hooks, bell. Ain't I a Woman: Black Women and Feminism. London: Pluto Press, 1982. p. 195.
} 
categorias identitárias que conformam as posições sociais dos sujeitos e estabelecem hierarquias e relações de poder entre essas posições.

Ao longo do segundo capítulo, procurei fornecer algumas das bases materiais e históricas da aludida construção social e linguística dos sujeitos. Nesse sentido, enfatizei o papel do colonialismo e das colonialidades do poder, do saber e do ser - constantemente reatualizadas para se adaptarem aos novos contextos - na produção e manutenção das categorias dicotômicas da modernidade, uma vez que essas categorias ou estruturas de dominação são sustentadas por processos econômicos e políticos, epistemológicos e subjetivos. Por fim, me apoiei em todas essas premissas para, no terceiro capítulo, investigar a influência desses discursos marcados pelas diferenças de gênero, de raça, etc., sobre as representações que os sujeitos têm de si e dos outros, sobre as posições que tentarão ocupar e sobre as expectativas construídas em razão dessas posições e representações, expectativas que, se por algum motivo, forem frustradas, podem desencadear violências. Esta análise foi necessária, pois me permitiu avaliar, a partir de um enfoque interseccional, a eficácia de algumas medidas jurídicas que pretendem coibir a violência contra a mulher, sem, contudo, atentar para outras dimensões do problema que não a ordem de gênero. 


\section{O processo de formação dos sujeitos e os mecanismos de produção das relações hierárquicas}

\subsection{Interseccionalidade e o sujeito do feminismo}

Por muito tempo, a dicotomia homem/mulher, baseada na diferença de gênero, garantiu a manutenção de uma estrutura de dominação em que o homem, a suposta representação de um sujeito universal, é colocado numa posição privilegiada, enquanto a mulher, por ocupar uma posição tida como particular, é marginalizada e destituída de direitos. Durante as últimas décadas, através de muitas lutas e reivindicações de ativistas feministas, a desigualdade de gênero deixou de ser uma justificava para a privação de direitos ${ }^{3}$, para se tornar um fator que evidenciava a discriminação e a opressão sofridas por mulheres e que, consequentemente, devia ser combatido, garantindo-se a efetiva proteção dos seus direitos.

Contudo, é preciso ter cuidado para que o argumento da existência da desigualdade de gênero não seja distorcido a ponto de o gênero ser considerado uma realidade anterior às relações que o constituem, o que conduziria apenas a uma solidificação dessas desigualdades e à produção dos sujeitos generificados. Interpretando Foucault, Judith Butler ${ }^{4}$ afirma que os sujeitos jurídicos são formados discursivamente e através de práticas políticas de exclusão e legitimação. Os sistemas jurídicos, ao regularem a vida e os atos

\footnotetext{
${ }^{3}$ Kimberlé Crenshaw assevera que a pretensão de universalidade da Declaração Universal de Direitos Humanos não se concretizou, pois seu olhar estava voltado exclusivamente para as experiências dos homens. Dessa forma, as mulheres permaneciam excluídas do seu âmbito de proteção toda vez que os abusos sofridos por elas eram reconhecidos como diferentes dos experimentados por homens, ou seja, considerados marginais em relação ao conceito clássico de direitos humanos. CRENSHAW, Kimberlé. Documento para o encontro de especialistas em aspectos da discriminação racial relativos ao gênero. Estudos Feministas, vol. 10, núm. 1, p. 172, jan. 2002.

${ }^{4}$ BUTLER, Judith. Problemas de gênero: feminismo e subversão da identidade. $11^{a}$ ed.. Rio de Janeiro: Civilização Brasileira, 2016. p. 18-19.
} 
dos sujeitos, os constituem de acordo com suas exigências. Essas mesmas estruturas jurídicas ocultam as operações políticas utilizadas nesta construção, através de mecanismos discursivos que colocam a lei como mera representante dos sujeitos, que supostamente são anteriores a ela. Essa naturalização do sujeito funciona, portanto, como fundamento de legitimidade da hegemonia reguladora da lei.

Isto posto, torna-se alarmante a percepção de que o sistema político, se utilizado de forma indevida, produz e reprime o sujeito do feminismo, ao invés de facilitar a sua emancipação. A definição de uma categoria estável de mulheres, muito embora uma proposta bem-intencionada, conduz inevitavelmente a uma reprodução e perpetuação das relações de gênero. Afinal, a tentativa de estabelecer um universo das mulheres preexistente à sua opressão apenas naturaliza o sistema de dominação que as constitui e ignora o contexto em que este se desenvolve 5 .

A propósito, vale lembrar que, ao tentar desestabilizar o pensamento hegemônico e construir novas possibilidades de existência e vida para as mulheres, o feminismo incorreu nos mesmos erros daqueles que criticava, o que foi evidenciado, em um primeiro momento, pelas feministas negras norteamericanas $^{6}$. Isso porque colocou no centro da categoria "mulher" uma identidade que se pretendia comum a todas, mas que, na verdade, excluía todas as mulheres que não se encaixavam naquele conceito restrito. Butler explica ${ }^{7}$ que essa identidade definida passou a ser questionada, pois claramente não havia um consenso a respeito de quem estaria incluído na categoria das mulheres. Com isso, a representatividade política almejada não alcançou aquelas que não eram reconhecidas como sujeito do feminismo.

\footnotetext{
${ }^{5}$ Ibid. p. 20-22.

6 DAVIS, Angela. Mulheres, raça e classe. São Paulo: Boitempo, 2016. 244 p; CRENSHAW, Kimberlé. Op. cit., p. 171-188; hooks, bell. Op. cit. 205 p.

${ }^{7}$ BUTLER, Judith. Op. cit., p. 17-20.
} 
Neste ponto, cumpre salientar que são muitos os sistemas de opressão que asseguram a perpetuação de certos grupos específicos no poder e a marginalização de outros. Dentre eles, incluem-se as discriminações por gênero, raça, etnia, classe social, casta, religião, origem nacional, deficiência e orientação sexual. Estas estruturas de dominação não são estanques e apartadas. Pelo contrário, interagem constantemente, através de uma mútua influência e constituição, garantindo, por fim, a complexa organização hierárquica do poder. Deste modo, não é possível combater uma dessas estruturas e, especificamente, a discriminação de gênero, sem considerar a relação dinâmica que ela possui com todas as outras. Daí a relevância do conceito de interseccionalidade cunhado por Kimberlé $\mathrm{Crenshaw}^{8}$, que torna aparente a realidade de diversos grupos sociais que estão numa posição extremamente vulnerável, na medida em que sofrem múltiplas e simultâneas formas de opressão, por se encaixarem em mais de um tipo de identidade historicamente subordinada.

As mulheres que sofrem mais de um tipo de discriminação não estão sujeitas à simples soma das consequências negativas de cada sistema de opressão no qual se inserem, pois isso significaria ignorar a interação complexa que existe entre eles. Por exemplo, a mulher negra não é suscetível apenas ao machismo e ao racismo que atingem mulheres brancas e homens negros, respectivamente. Na realidade, a sua identidade de gênero faz com que ela esteja sujeita a formas e intensidades de subordinação por raça que homens negros desconhecem. Por outro lado, a sua identidade de raça a faz sofrer manifestações específicas ou acentuadas de discriminação de gênero que, em geral, são ignoradas por mulheres brancas.

Ademais, um dos fatores que mais contribuem para a vulnerabilidade das mulheres marginalizadas é a invisibilidade de sua condição de subordinação superposta. Crenshaw utilizou os termos superinclusão e

\footnotetext{
${ }^{8}$ CRENSHAW, Kimberlé. Op. cit., p. 177.
} 
subinclusão $^{9}$ para explicar o funcionamento desta invisibilidade. A superinclusão é o mecanismo através do qual uma condição específica de um subgrupo de mulheres é vista como um problema das mulheres em geral. No caso, há uma absorção indevida pela estrutura de gênero dos elementos interseccionais envolvidos na questão ${ }^{10}$. Por sua vez, a subinclusão ocorre quando um problema que atinge um subgrupo de mulheres não é reconhecido como um problema de gênero ou, ainda, como um problema do grupo marginalizado do qual fazem parte, uma vez que suas experiências específicas de discriminação não são comumente experimentadas por mulheres dos grupos dominantes ou por homens dos grupos a que pertencem ${ }^{11}$. Como bem resumiu Crenshaw: "nas abordagens subinclusivas da discriminação, a diferença torna invisivel um conjunto de problemas; enquanto que, em abordagens superinclusivas, a própria diferença é invisível"12.

O perigo da superinclusão e da subinclusão reside na análise inadequada dos problemas que atingem certos grupos de mulheres, por conta da desconsideração negligente de aspectos relevantes e intrinsecamente relacionados à sua condição, o que, como resultado, inviabiliza intervenções efetivamente capazes de melhorar a situação de vulnerabilidade desses grupos. As estratégias políticas e jurídicas que buscam solucionar a discriminação de gênero a partir deste olhar míope que ignora a experiência de mulheres sujeitas a mais de um tipo de subordinação não só serão inócuas no que tange aos seus objetivos, como muito provavelmente reproduzirão e reforçarão as desigualdades que pretendem coibir, excluindo aquelas mulheres de seu âmbito

\footnotetext{
${ }^{9}$ Ibid. p. 174-177.

${ }^{10}$ Crenshaw faz referência ao discurso sobre o tráfico de mulheres para exemplificar essa absorção indevida, pois em que pese a notoriedade da relação entre o tráfico e a marginalização por raça e por classe, o problema continua sendo tratado de forma desvinculada de toda essa complexidade, com ênfase exclusivamente no fator de gênero. Ibid. p. 175.

11 Para exemplificar o fenômeno, Crenshaw menciona a esterilização forçada de mulheres marginalizadas em todo o mundo e, em especial, nos Estados Unidos, na década de 50. Neste contexto, a dimensão de gênero do problema impede que ele seja identificado como uma questão racial ou étnica, muito embora seja um caso flagrante de discriminação contra povos racializados. Ibid. p. 175.

${ }^{12}$ Ibid. p. 176.
} 
protetivo. Os sistemas de opressão não podem ser compreendidos de maneira independente, pois cada um deles exerce uma influência constitutiva sobre os outros. Sendo assim, se esta articulação complexa for desconhecida ou ignorada, as propostas encontradas para desconstruí-los serão ineficazes ou mesmo contraproducentes ${ }^{13}$.

Os argumentos acima expostos evidenciam a importância da descentralização do sujeito do feminismo e do reconhecimento de sua heterogeneidade. Como vimos, Butler também critica a suposta identidade comum entre as mulheres. Para ela, esta ficção, como deve ser chamada, não considera as diversas formas de subordinação a que mulheres de culturas completamente distintas estão sujeitas. Segundo a autora: "o gênero nem sempre se constituiu de maneira coerente ou consistente nos diferentes contextos históricos" ${ }^{14}$. A produção das relações de gênero e, consequentemente, a própria formação da mulher, depende da cultura na qual ela está inserida, o que, por si só, já descaracterizaria a unidade do sujeito do feminismo. Mas, além disso, como mencionado acima, há uma constante interseção entre gênero e outros fatores que constituem as identidades, como raça, etnia, classe social e orientação sexual.

Por isso, a antiga crença em uma estrutura universal de dominação masculina aplicável indistintamente a todas as mulheres denota uma visão autoritária e colonialista do ocidente que, por um lado, pretende apropriar-se das culturas não ocidentais para enfatizar formas de opressão tipicamente experimentadas por ele, confirmando, em tese, a ficção da identidade comum, e, por outro, critica essas mesmas realidades quando a aproximação com as suas experiências não é possível, normalmente justificando esta diferença por meio da alusão a um barbarismo não ocidental ${ }^{15}$.

\footnotetext{
${ }^{13}$ Ibid. p. 177.

${ }^{14}$ BUTLER, Judith. Op. cit., p. 21.

${ }^{15}$ Ibid. p. 21-22.
} 
Paradoxalmente, no esforço de alcançar uma ampla representatividade, o feminismo apostou em estratégias unificadoras que serviram apenas para (i) excluir mulheres que não correspondiam àquele sujeito estável, (ii) fragmentar a teoria feminista, haja vista que muitas mulheres recusaram esta aparente representatividade, e (iii) perpetuar a opressão de gênero, na medida em que contribuíram para a reificação do sujeito mulher.

À luz de tais considerações, Judith Butler propõe uma reformulação do feminismo, que nunca deve abster-se de criticar as "categorias de identidade que as estruturas jurídicas contemporâneas engendram, naturalizam e imobilizam"16 e defende uma nova política feminista, que abra mão de uma unidade fictícia e reconheça a construção variável da identidade das mulheres. Este trabalho pretende aprofundar, a partir do conceito de interseccionalidade, as provocações da autora a respeito da interação entre gênero e as diversas modalidades de opressão reproduzidas e perpetuadas pelo sistema jurídico, e ressaltar os efeitos excludentes causados por estes mecanismos políticos.

A princípio, a crítica ao sujeito do feminismo feita por Butler poderia parecer inconciliável com a proposta de Kimberlé Crenshaw, na medida em que a primeira pretende desconstruir as categorias de identidade, enquanto a segunda enfatiza o papel das múltiplas identidades nas variadas formas de discriminação. Entretanto, a contradição entre as autoras é apenas aparente, pois, como vimos, as duas enxergam o mesmo problema, qual seja, a suposta unidade da categoria "mulher" e a consequente exclusão daquelas que não pertencem ao grupo dominante. Ambas apontam para a importância da interação do gênero com outros sistemas de opressão.

Butler não nega a existência das múltiplas identidades. Ao contrário, é exatamente em razão dessa diversidade que a autora rejeita a noção de unidade. Ela destaca, por exemplo, o valor de políticas de coalizão que abrem espaço para o diálogo entre mulheres diferentemente posicionadas, que articulam

\footnotetext{
${ }^{16}$ Ibid. p. 24.
} 
identidades distintas no âmbito do grupo reconhecidamente plural ${ }^{17}$. Sua preocupação, porém, é evitar o enrijecimento dessas identidades, pois isso impossibilitaria a formulação de novos conceitos por meio de ações políticas concretas. Para ela, a emancipação das mulheres depende da constante reconstrução das categorias identitárias, através de estratégias subversivas de deslocamento das mesmas. Portanto, o que não pode ocorrer é uma definição prévia dessas identidades, sob o risco de serem cometidos os mesmos erros do passado. Será a atuação política concreta das coalizões acima referidas que moldará os contornos das identidades, que deverão estar sempre abertas a questionamentos e reformulações:

Essa abordagem antifundacionalista da política de coalizões não supõe que a 'identidade' seja uma premissa, nem que a forma ou significado da assembleia coalizada possa ser conhecida antes de realizar-se na prática. Considerando que a articulação de uma identidade nos termos culturais disponíveis instaura uma definição que exclui previamente o surgimento de novos conceitos de identidade nas ações politicamente engajadas e por meio delas, a tática fundacionalista não é capaz de tomar como objetivo normativo a transformação ou expansão dos conceitos de identidade existentes. Além disso, quando as identidades ou as estruturas dialógicas consensuais, pelas quais as identidades já estabelecidas são comunicadas, não constituem o tema ou o objeto da política, isso significa que as identidades podem ganhar vida e se dissolver, dependendo das práticas concretas que as constituam. (...). O gênero é uma complexidade cuja totalidade é permanentemente protelada, jamais plenamente exibida em qualquer conjuntura considerada. Uma coalização aberta, portanto, afirmaria identidades alternativamente instituídas e abandonadas, segundo as propostas em curso; tratar-se-á de uma assembleia que permita múltiplas convergências e divergências, sem obediência a um telos normativo e definidor ${ }^{18}$.

Crenshaw, por sua vez, reconhece que o processo de construção das categorias identitárias está intimamente ligado ao exercício do poder de nomear e, por meio desta nomeação, subordinar. Contudo, a autora chama a atenção para a relação dialética presente neste processo de categorização, e demonstra que os grupos subordinados, exercendo uma agência que resiste às assimetrias de poder, são capazes de deslocar o significado da nomeação inicialmente imposta pelos grupos dominantes, forjando, assim, uma

\footnotetext{
${ }^{17}$ Ibid. p. 39.

${ }^{18}$ Ibid. p. 41-42.
} 
identidade subversiva e empoderante ${ }^{19}$. Como veremos no tópico seguinte, essa visão adequa-se perfeitamente à teoria de Butler a respeito da construção linguística dos sujeitos.

Por fim, no que se refere às exclusões e invisibilidades presentes no interior de grupos identitários, causadas pela associação e equiparação da realidade do grupo como um todo com as experiências particulares de alguns por exemplo, mulheres brancas e homens negros -, a autora sugere, como solução, que interpretemos os grupos identitários como coalizões efetivas ou em potencial, que devem estar sempre atentas às posições interseccionais ocupadas por seus integrantes ${ }^{20}$. Dessa forma, para que os perigos apontados por Crenshaw - em decorrência da invisibilidade interseccional ${ }^{21}$ - sejam afastados, as contradições e divergências inerentes a uma coalizão plural devem permanecer intactas e aparentes, com uma abertura dialógica que assegure um amplo espaço para dissensões, inclusive em relação às estratégias e ações políticas visadas, pois os interesses envolvidos e os objetivos almejados muitas vezes não serão os mesmos, o que está longe de ser um problema. Como disse Butler, "a 'unidade' da categoria das mulheres não é nem pressuposta nem desejada"22, e os possíveis conflitos advindos dessa heterogeneidade, enquanto viabilizadores de um processo efetivamente democrático, são bem-vindos.

\subsection{A construção social e linguística dos sujeitos}

Inicialmente, a distinção entre sexo e gênero tinha por objetivo impedir que o determinismo biológico do primeiro restringisse as possibilidades

\footnotetext{
${ }^{19}$ CRENSHAW, Kimberlé. Mapping the Margins: Intersectionality, Identity Politics, and Violence against Women of Color. Stanford Law Review, vol. 43, n. 6, p. 1297, jul. 2010.

${ }^{20}$ Ibid. p. 1299.

${ }^{21}$ As acima mencionadas subinclusão e superinclusão. CRENSHAW, Kimberlé. Documento para o encontro de especialistas em aspectos da discriminação racial relativos ao gênero. p. 174-177.

${ }^{22}$ BUTLER, Judith. Op. cit., p. 40.
} 
emancipatórias do segundo. Nesse sentido, a nova concepção de gênero, com ênfase no seu caráter culturalmente construído, buscava retirá-lo do âmbito restrito e delimitado do sexo $^{23}$. Entretanto, em que medida é possível distinguir efetivamente os dois termos e até que ponto essa distinção teórica é produtiva, ou seja, capaz de alcançar seus propósitos emancipatórios? Isso porque a naturalização do sexo pode ser, ela mesma, uma construção social que sustenta e justifica a inevitabilidade do gênero. Afinal, ainda que este comporte variações culturais, ele será inscrito, segundo este discurso, em um corpo supostamente já sexuado, o que acaba aniquilando a multiplicidade de significados que, em tese, poderiam ser adquiridos com o gênero. Seguindo esta linha, é sintomático o fato de ambos serem estruturados em termos binários. Se as possibilidades abrangidas pelo gênero não são tão restritas quanto as do sexo, então por que existiriam apenas dois gêneros, assim como dois sexos, o masculino e o feminino? Por essa perspectiva, a separação dos conceitos apenas obscurece os mecanismos pelos quais o gênero produz discursivamente o sexo, ao mesmo tempo em que o coloca como anterior à cultura:

Se o sexo é, ele próprio, uma categoria tomada em seu gênero, não faz sentido definir o gênero como a interpretação cultural do sexo. O gênero não deve ser meramente concebido com a inscrição cultural de significado num sexo previamente dado (uma concepção jurídica); tem de designar também o aparato mesmo de produção mediante o qual os próprios sexos são estabelecidos. Resulta daí que o gênero não está para a cultura como o sexo para a natureza; ele também é o meio discursivo/cultural pelo qual "a natureza sexuada" ou um "sexo natural" é produzido e estabelecido como "pré-discursivo", anterior à cultura, uma superfície politicamente neutra sobre a qual age a cultura. (...). Na conjuntura atual, já está claro que colocar a dualidade do sexo num domínio pré-discursivo é uma das maneiras pelas quais a estabilidade interna e a estrutura binária do sexo são eficazmente asseguradas. Essa produção do sexo como pré-discursivo deve ser compreendida como efeito do aparato de construção cultural que designamos por gênero. Assim, como deve a noção de gênero ser reformulada, para abranger as relações de poder que produzem o efeito de um sexo pré-discursivo e ocultam, desse modo, a própria operação da produção discursiva? ${ }^{24}$.

\footnotetext{
${ }^{23}$ Ibid. p. 194.

${ }^{24}$ Ibid. p. 27-28.
} 
A aproximação entre os dois termos torna-se ainda mais evidente se verificarmos que as pesquisas biomédicas a respeito do sexo e de seus fatores "determinantes", frequentemente utilizadas como argumento de autoridade na defesa do sexo como fato natural, são constante e profundamente influenciadas por hipóteses e raciocínios repletos de estereótipos de gênero, visto que a produção do conhecimento científico não pode ser separada do paradigma no qual está inserida e, sobretudo, tem seu discurso determinado pela linguagem, que é marcada pelo gênero ${ }^{25}$.

Além disso, é importante ressaltar que o corpo não pode ser interpretado como um meio passivo, inerte, através do qual significados culturais posteriores nele serão inscritos. Essa visão distorcida é corroborada pelos velhos dualismos que atravessam o pensamento hegemônico ocidental e instituem uma hierarquia entre a natureza, associada ao corpo, ou ainda, de modo mais preciso, ao corpo feminino, e a cultura, relacionada com a mente masculina, e que deverá subjugar aquela e atribuir-lhe significado, sem o qual a natureza não passará de uma "facticidade muda"26. Entretanto, não é possível falar na existência de um corpo anterior à significação, pois é a própria cultura que constrói os contornos daquele, estabelecendo limites ao comportamento social que de forma alguma podem ser ultrapassados - por exemplo, práticas sexuais que não estão em conformidade com a matriz heterossexual são proibidas - e, com isso, estabilizando as fronteiras corporais ao ponto de elas adquirirem uma aparência natural.

Neste contexto, Butler critica ${ }^{27}$ as ontologias filosóficas que contribuem para a naturalização do sexo, na medida em que dão suporte a uma interpretação do gênero ou do sexo como substância ou, em suas palavras, como um "ser idêntico a si mesmo". A autora sugere que a suposta unidade, coerência e estabilidade das identidades de gênero são corroboradas por uma

\footnotetext{
${ }^{25}$ Ibid. p. 190-191.

${ }^{26}$ Ibid. 75-76, 223-224.

${ }^{27}$ Ibid. p. 46-50.
} 
manobra linguística que pressupõe que a estrutura gramatical sujeito/predicado nada mais é do que a descrição de uma realidade ontológica, presente na relação substância/atributo. Dessa forma, homem e mulher seriam substantivos, ou seja, uma pessoa é um sexo (ou é um gênero) e possui atributos masculinos ou femininos vinculados a esse sexo (ou gênero).

Esta aparência de uma substância permanente ${ }^{28}$, porém, é uma ficção, pois o conjunto de atributos associado a um gênero não passa de uma escolha, um ideal normativo imposto através de práticas reguladoras e discursos hegemônicos que reprimem aqueles que não se conformam a ele. Assim, as identidades de gênero instituídas artificialmente a partir da regulação dos atributos se tornam as únicas identidades culturalmente inteligíveis, enquanto todas as outras são relegadas ao terreno da incoerência.

Mas o que seria um gênero culturalmente inteligível? Butler sustenta que uma matriz de normas de gênero estabelece uma relação obrigatória de continuidade e causalidade entre sexo, gênero, desejo sexual e sua prática. Enquanto essa relação estiver intacta e em conformidade com o pensamento hegemônico, a coerência do gênero é reconhecida. Por outro lado, outras combinações desses fatores seriam reputadas como anormais e incompreensíveis:

A noção de que pode haver uma 'verdade' do sexo, como Foucault a denomina ironicamente, é produzida precisamente pelas práticas reguladoras que geram identidades coerentes por via de uma matriz de normas de gênero coerentes. A heterossexualização do desejo requer e institui a produção de oposições discriminadas e assimétricas entre 'feminino' e 'masculino', em que estes são compreendidos como atributos expressivos de 'macho' e de 'fêmea'. A matriz cultural por meio da qual a identidade de gênero se torna inteligível exige que certos tipos de 'identidade' não possam 'existir' - isto é, aqueles em que o gênero não decorre do sexo e aqueles em que as práticas do desejo não 'decorrem' nem do 'sexo' nem do 'gênero'. Nesse contexto, 'decorrer' seria uma relação política de direito instituído pelas leis culturais que estabelecem e regulam a forma e o significado da sexualidade. Ora, do ponto de vista desse campo, certos tipos de 'identidade de gênero' parecem ser meras falhas do desenvolvimento ou impossibilidades lógicas, precisamente por não se conformarem às normas de inteligibilidade cultural. Entretanto, sua persistência e proliferação criam oportunidades críticas de expor os limites e os objetivos

${ }^{28}$ Ibid. p. 55 . 
reguladores desse campo de inteligibilidade e, consequentemente, de disseminar, nos próprios termos dessa matriz de inteligibilidade, matrizes rivais e subversivas de desordem do gênero ${ }^{29}$.

A unidade pressuposta entre sexo, gênero e desejo é fundamental para a concretização da ideia de um eu substantivo - ou essencializado - com existência prévia às relações sociais. Desta maneira, o sexo exigiria não só um gênero determinado, mas também um desejo necessariamente heterossexual, ou seja, dirigido ao gênero oposto. Como se vê, a heterossexualidade institucional depende e, concomitantemente, produz o caráter binário e assimétrico do gênero ${ }^{30}$. Ademais, ela reforça profundamente a visão do sexo como fato natural, pois coloca em questão a reprodução da espécie humana. Seriam o sexo e o desejo heterossexual um imperativo biológico com o propósito de garantir a procriação? Esse raciocínio, como bem alertado por Adriana Vidal de Oliveira em "Constituição e Direitos das Mulheres"31, incorre no erro de confundir e inverter a causa pelo efeito. A sexualidade, em que pese ocasionalmente ter como consequência a procriação, não tem nesta última uma finalidade. É dizer: a sexualidade não existe para ou em razão da procriação, pois um efeito nunca será a justificativa da existência de sua causa, mas sim o contrário.

Qual seria, então, a origem da sexualidade? Butler, invocando Foucault, afirma que "a sexualidade é uma organização historicamente específica do poder, do discurso, dos corpos e da afetividade" 32 . Em primeiro lugar, surge a necessidade de atentar para o fato de que a sexualidade, tal como a conhecemos, está inserida no âmbito de um contexto histórico determinado. Sendo assim, os corpos, ao serem submetidos a um conjunto de regulações,

\footnotetext{
${ }^{29}$ Ibid. p. 44.

${ }^{30}$ Isso não significa, porém, que gays e lésbicas estão imunes às regulações impostas pela categoria do sexo, ou que relacionamentos homossexuais não possam reproduzir estruturas psíquicas e de poder tipicamente heterossexuais. Ibid. p. 211. No mesmo sentido: OLIVEIRA, Adriana Vidal de. Constituição e direitos das mulheres: uma análise dos estereótipos de gênero na Assembleia Constituinte e suas consequências no texto constitucional. Curitiba: Juruá, 2015. p. 45-46.

${ }^{31}$ OLIVEIRA, Adriana Vidal de. Op. cit., p. 42.

${ }^{32}$ BUTLER, Judith. Op. cit., p. 162.
} 
tornam-se sexuados e adquirem contornos estáveis - ainda que não permanentes ou imutáveis -, isto é, são constituídos por um discurso que, a serviço das relações de poder, estabelece as categorias do sexo e exige comportamentos em conformidade com elas. Esse mesmo discurso reproduzido constantemente em diversos cenários políticos - incute a crença em um sexo natural que, por sua vez, garante que os mecanismos responsáveis por sua gênese permaneçam encobertos.

Essa categoria fictícia viabiliza, de outro modo, a interpretação do desejo sexual - dirigido ao sexo oposto - como um fator que expressa a verdadeira essência do corpo sexuado, concebido, por um lado, como a causa deste desejo e, por outro, como o meio específico - leia-se, único meio possível - através do qual os prazeres e sensações corporais adquirem sentido e tornam-se inteligíveis ${ }^{33}$. Nesse contexto, é significativo o fato de que a sexualidade é descrita, quase sempre, em termos de uma heterossexualidade pressuposta. Esta realidade torna-se facilmente perceptível com um simples exemplo: os pais, ao explicarem para seus filhos o que é uma relação sexual, costumam fazer referência à vagina da mulher e ao pênis do homem, bem como a uma necessária interação entre as referidas partes corporais. Portanto, em nossa linguagem marcada não só pelo gênero, mas também pela heterossexualidade compulsória, ser sexuado significa ser heterossexual. A tradução semântica entre os termos ocorre de forma automática.

Entretanto, a categoria do sexo, assim como qualquer outra categoria, nada mais é do que a reunião artificial de elementos supostamente semelhantes, os quais são separados daqueles classificados como diferentes. Esta é a forma através da qual os seres humanos organizam o mundo, a fim de torná-lo inteligível. Além disso, essas categorias viabilizam a comunicação, pois a linguagem funciona por meio de generalizações, sem as quais seria

\footnotetext{
${ }^{33}$ Ibid. p. 166.
} 
muito difícil compreender alguém durante uma conversa ${ }^{34}$. O perigo, contudo, reside na crença de que essas categorias ou generalizações são descritivas de uma realidade ontológica anterior, sobretudo quando as categorias criadas estabelecem hierarquias, o que conduz inevitavelmente à opressão.

Dessa forma, dizer que essas categorias não existem fora da linguagem - e, portanto, dizer que, se ultrapassarmos as barreiras firmadas pelas generalizações, veremos que uma mulher é tão diferente de outra quanto o é de um homem - não significa dizer que sua existência no interior da linguagem deva ser subestimada. Em outras palavras, o fato de essas categorias serem uma construção linguística não as torna menos reais, isto é, menos capazes de moldar o mundo inteligível.

Um bom exemplo da influência que certas categorias têm sobre a estruturação da sociedade é a distinção entre pessoas negras e brancas, que teve respaldo, durante o século XIX, em "pesquisas científicas", que afirmavam constatar diferenças biológicas essenciais entre elas. Hoje em dia, todos - ou espera-se que assim o seja - reconhecem que essas teorias se basearam unicamente em preconceitos e interesses políticos e econômicos. Todavia, não há como desconhecer os efeitos catastróficos advindos dessa categorização hierárquica que justificou a opressão e a escravização de diversos povos africanos e que, a despeito das exaustivas comprovações científicas em sentido contrário, ainda está em operação, alimentada pelo contexto socioeconômico desenhado a partir daquele cenário opressivo. De modo perverso, as categorias produzem as diferenças que supostamente já existiam. Isto posto, torna-se imprescindível lutar por sua desconstrução ou ressignificação, sem, no entanto, negar sua realidade cultural, para que seus mecanismos produtivos não sejam ocultados.

\footnotetext{
34 STRUCHINER, Noel. O direito como um campo de escolhas: por uma leitura das regras como relações. In: RODRIGUEZ, José Rodrigo; COSTA, Carlos Eduardo Batalha da Silva e; BARBOSA, Samuel Rodrigues (Org). Nas fronteiras do formalismo: a função social da dogmática jurídica hoje. São Paulo: Saraiva, 2010, p. 109.
} 
No que tange à categoria do sexo, ela reúne arbitrariamente órgãos, características anatômicas e funções biológicas e as associa com condutas e prazeres específicos, agregando todos esses elementos em uma unidade fictícia $^{35}$. Não há, entretanto, uma conexão necessária entre pelos na superfície do corpo, voz grossa e testículos, inclusive porque muitos homens não possuem alguma - ou mesmo nenhuma - dessas características, enquanto, de outro modo, muitas mulheres as detêm. Da mesma forma, incontáveis mulheres nascem sem útero ou ovários, ou os retiram em algum momento, assim como muitos homens, durante a puberdade, desenvolvem seios normalmente retirados cirurgicamente ${ }^{36}$.

Esta unidade artificial também deve ser compreendida como uma heterogeneidade artificial, pois a união desses fatores implica a segregação entre homens e mulheres, bem como a separação de certas partes corporais do restante do corpo, o que reduz o universo de prazeres sexuais a um número limitado de partes consideradas erógenas:

\begin{abstract}
Existe um corpo "físico" anterior ao corpo percebido? Questão de resposta impossível. Não só a junção de atributos sob a categoria do sexo é suspeita, mas também o é a própria discriminação das "características". O fato de o pênis, de a vagina, de os seios e assim por diante serem denominados partes sexuais corresponde tanto a uma restrição do corpo erógeno a essas partes quanto a uma fragmentação do corpo como um todo. Com efeito, a "unidade" imposta ao corpo pela categoria do sexo é uma "desunidade", uma fragmentação e compartimentação, uma redução da erotogenia ${ }^{37}$.
\end{abstract}

\footnotetext{
${ }^{35}$ BUTLER, Judith. Op. cit., p. 162.

36 "O termo ginecomastia refere-se ao aumento das mamas masculinas, assemelhando-se às femininas (...). Mais comum do que se imagina, a ginecomastia é frequente em adolescentes e geralmente involui espontaneamente com a idade. Pode ter causa fisiológica (natural como a do adolescente) ou por drogas (...) e medicamentos. (...). A cirurgia da ginecomastia visa a retirada da gordura, se existente, e da glândula mamária. (...). É uma cirurgia estética, visto que a ginecomastia é benigna e dificilmente evolui para câncer de mama". Mais informações disponíveis em: 〈http://www.cirurgiaestetica.com.br/ginecomastia-quando-o-homem-tem-mamas/>.

${ }^{37}$ BUTLER, Judith. Op. cit., p. 199. No mesmo sentido: "O sexo promove uma unidade artificial aos corpos, que na verdade constitui uma fragmentação deles ou os divide em compartimentos na medida em que estabelece categorias considerando algumas partes específicas dos corpos. Isso pode parecer a princípio contraditório, mas a unidade dos corpos reunidos a partir de um alinhamento com um ou outro sexo é utilizada com o intuito de dividir, segregar, restringir, interditar e dominar, fazendo uso dos atos de fala para estabilizar essas divisões e dar o caráter natural a elas. Em outros termos, a divisão dos sexos implica uma categorização a partir de uma determinada parte ou função do corpo, a reprodução, desprezando todos os aspectos comuns e diferentes entre os inúmeros corpos. A partir
} 
A categoria do sexo engloba um conjunto de atributos, mas, ao mesmo tempo, paradoxalmente, estabelece a estrutura binária do sexo - existem apenas dois sexos, o masculino e o feminino - e sua univocidade - não é possível ser os dois sexos ao mesmo tempo. Onde se situam, então, aqueles que não podem ser descritos nesses termos, seja porque possuem atributos "misturados"38, seja porque seus órgãos e elementos anatômicos não correspondem - de acordo com o sistema normativo cisgênero - a suas sensações, sua conduta e seus processos psicossomáticos, como por exemplo a transgeneridade? Se considerarmos a complexidade do corpo/mente humano e a quantidade de combinações possíveis a partir desses atributos, veremos que a unidade e a estrutura binária do sexo ficam instantaneamente comprometidas ${ }^{39}$. Cabe ressaltar que, exatamente por questionarem e ameaçarem as normas do sistema cisgênero, as pessoas transgêneras estão constantemente sujeitas a fortes cargas de violência - física, verbal, psicológica, sexual - e os espaços que podem ser livremente ocupados por homens e mulheres trans ou travestis por exemplo, no mercado de trabalho - são extremamente reduzidos, especialmente no caso das últimas.

Dito isso, como podemos afastar o discurso do gênero como algo substancial ou intrínseco e inferir que, na verdade, esse efeito substantivo é produzido? De forma bastante elucidativa, Butler explica ${ }^{40}$ que o gênero é uma atividade, uma performance, uma repetição incessante de atos performativos que estilizam o corpo e garantem sua estabilidade, o que promove a ilusão de uma essência interna que seria expressa por este corpo. Segundo a autora, "não há identidade de gênero por trás das expressões do gênero; essa identidade é

disso, consegue-se perceber a arbitrariedade que a divisão sexual pode gerar. Isso não significa ignorar as diferenças entre um corpo macho e um corpo fêmea, mas traz a possibilidade de enxergar semelhanças entre corpo macho e fêmea, bem como diferenças entre dois corpos machos e dois corpos fêmeas, em termos bem simplificados". OLIVEIRA, Adriana Vidal de. Op. cit., p.42-43.

38 Neste caso, refiro-me não só a hermafroditas em um sentido amplo - isto é, incluindo os denominados pseudo-hermafroditas, que não possuem os órgãos reprodutivos de ambos os sexos - mas também a qualquer pessoa que apresente alguma característica física tida como do sexo oposto.

${ }^{39}$ Ibid. p. 191.

${ }^{40}$ Ibid. p. 195 e 235. 
performaticamente constituída pelas próprias 'expressões' tidas como seus resultados" ${ }^{41}$. Não é demais enfatizar que a reiteração constante dos mesmos gestos e atos é fundamental para a manutenção desta aparência de naturalidade. Assim, nas palavras de Adriana Vidal de Oliveira:

A identidade é consequência dos atos de imitação, reprodução e segregação. Esses atos que compõe os corpos são os performativos e a identidade que eles se propõem a retratar são produções fabricadas pelos sinais emitidos pelos corpos, desde gestos, comportamentos, vestimentas até os atos de fala propriamente ditos. O encadeamento de gestos e atos e de produção de desejo, bem como o ritual que envolve esses procedimentos forjam a ilusão de uma existência prévia que é mantida pelo aparato discursivo para perpetuar a lógica reprodutiva na sexualidade e as divisões de função que decorrem da "constatação" do sexo a partir de uma adequação desses papéis sociais às supostas aptidões corporais e emocionais ${ }^{42}$.

A performance do gênero é imposta por normas sociais e discursos que regulam o comportamento e legitimam práticas reiteradas que consolidam estereótipos de gênero. Neste contexto, o papel da linguagem ${ }^{43}$ não pode ser ignorado, na medida em que esta possui o poder de atuar sobre os corpos e constituir a realidade, sob o falso pretexto de estar apenas descrevendo-os. A propósito, é recomendável apresentar brevemente as considerações feitas por Adriana Vidal de Oliveira em sua supracitada obra. Ao longo do capítulo $1^{44}$, a autora identifica o quanto o filósofo da linguagem J. L. Austin influenciou Butler, ao formular uma teoria inovadora a respeito dos atos de fala. Para Austin, dizer algo é sempre um fazer, uma ação que produz a realidade, uma intervenção sobre o espaço no qual a fala se dá. Todo ato de fala é um ato performativo e, sendo assim, quando falamos alguma coisa, não estamos simplesmente constatando uma verdade com existência prévia. A pretensão descritiva da linguagem foi desmistificada por Austin como sendo nada mais do que uma falácia, mas que, no entanto, tem força suficiente para fazer com que esta realidade constituída pareça decorrer da natureza ${ }^{45}$.

\footnotetext{
${ }^{41}$ Ibid. p. 56.

${ }^{42}$ OLIVEIRA, Adriana Vidal de. Op. cit., p. 54.

${ }^{43}$ BUTLER, Judith. Op. cit., p. 200-202.

${ }^{44}$ OLIVEIRA, Adriana Vidal de. Op. cit., p. 21-82.

${ }^{45}$ Ibid. p. 43-44.
} 
Isto posto, torna-se muito mais fácil compreender o que Butler entende por atos performativos no contexto da formação das identidades de gênero. Muito embora a performance do gênero não se restrinja a atos de fala, envolvendo também vestimenta, exercícios físicos, alimentação, maquiagem, depilação e outros ${ }^{46}$, aqueles cumprem um papel indispensável na consolidação do corpo generificado. A maneira como os indivíduos falam, a imagem que eles pretendem transmitir e os gestos utilizados durante o ato instituem, ou melhor, reproduzem - pois não passam de práticas imitativas - os estereótipos de gênero.

É interessante notar que os hábitos corporais - não só aqueles relacionados ao gênero, mas toda e qualquer prática corporal ritualística, isto é, que acumula sua força na repetição -, ao mesmo tempo em que são impulsionados por normas e convenções sociais, são também os responsáveis pela consolidação dessas mesmas normas, na medida em que sedimentam a crença na realidade social por eles reproduzida ${ }^{47}$.

No entanto, muito embora o poder constitutivo da linguagem possa servir a propósitos repressivos, ele pode, da mesma forma, ser a chave para a emancipação ${ }^{48}$. Aliás, convém mencionar que, para Butler, não há como transcender o socialmente construído. Se há alguma possibilidade de ressignificação, esta se dará no interior da própria linguagem ${ }^{49}$, através de uma estratégia de repetição subversiva que desloca os significados anteriormente instituídos. Para ilustrar seu pensamento, a autora utiliza como exemplo as drag queens e travestis, uma vez que estas, ao parodiarem o gênero, colocam em xeque sua pretensão de originalidade. Vê-se que o que se está imitando

\footnotetext{
${ }^{46}$ É interessante notar que os atos de fala são inseparáveis do corpo que os enuncia. Todo ato de fala é um ato corporal, e essa interação complexa entre corpo e discurso pode ter consequências imprevisíveis, uma vez que os gestos e ações corporais podem, inadvertidamente, tanto reforçar a ideia que se quer transmitir, quanto confundir o interlocutor, ou mesmo induzi-lo a captar uma mensagem distinta da que se pretendia originalmente comunicar. BUTLER, Judith. Excitable speech: a politics of the performative. Nova York: Routledge, 1997. p. 10.

${ }^{47}$ Ibid. p. 155.

${ }^{48}$ BUTLER, Judith. Problemas de gênero: feminismo e subversão da identidade, p. 202.

${ }^{49}$ Ibid. p. 164 e 250.
} 
nada mais é do que uma cópia que, por sua vez, imita outra cópia e assim por diante:

Ao imitar o gênero, a drag revela implicitamente a estrutura imitativa do próprio gênero - assim como sua contingência. Aliás, parte do prazer, da vertigem da performance, está no reconhecimento da contingência radical da relação entre sexo e gênero diante das configurações culturais de unidades causais que normalmente são supostas naturais e necessárias. No lugar da lei da coerência heterossexual, vemos o sexo e o gênero desnaturalizados, por meio de uma performance que confessa sua distinção e dramatiza o mecanismo cultural da sua unidade fabricad $a^{50}$.

No mesmo sentido, quando um homem gay se identifica com o feminino - empregando, inclusive, o termo ela para referir-se a si mesmo - e uma mulher lésbica com o masculino, eles abrem o caminho para a desnaturalização do sexo e do gênero, pois, ao evidenciarem a inexistência de uma relação causal entre corpo macho e masculino e corpo fêmea e feminino, eles desestabilizam as bases nas quais esses conceitos se apoiam ${ }^{51}$.

Por outro lado, os atos de fala não se resumem à formação do sujeito falante, mas são também responsáveis pela constituição do sujeito a quem a fala é dirigida. Em seu livro intitulado "Excitable speech: a politics of the performative", Butler ressalta ${ }^{52}$ a vulnerabilidade linguística dos sujeitos em relação à interpelação e à nomeação, que promovem a existência social do corpo interpelado/nomeado. Nesse sentido, o Outro ${ }^{53}$, aquele que dirige a palavra, não simplesmente reconhece o sujeito endereçado, não percebe aquele corpo pelo que ele já é, mas o constitui, inserindo-o em determinado espaço/tempo e inaugurando sua existência na linguagem. Assim, todo ato de interpelação é, de certo modo, violento, pois impõe ao sujeito nomeado uma

\footnotetext{
${ }^{50}$ Ibid. p. 237.

${ }^{51}$ Ibid. p. 212-214. OLIVEIRA, Adriana Vidal de. Op. cit., p. 46.

52 BUTLER, Judith. Excitable speech: a politics of the performative. p. 5.

${ }^{53}$ Neste ponto, é necessário fazer a seguinte ressalva: nem sempre o sujeito será nomeado por outro sujeito. Esta interpelação pode ocorrer por meio de mecanismos institucionais difusos - papéis de adoção, formulários burocráticos, censos demográficos, etc. Ibid. p. 34.
} 
realidade introduzida pelo Outro. A identidade lhe é conferida mesmo contra sua vontade ${ }^{54}$ ou sem seu conhecimento.

Ao mesmo tempo, é tão somente a partir desta introdução à vida linguística que surge a possibilidade de agência, isto é, que o sujeito interpelado pode, ele mesmo, interpelar e nomear. O sujeito, portanto, se torna dependente deste endereçamento, pois só assim adquirirá espaço no meio discursivo, pressuposto indispensável para que assuma a posição de agente político $^{55}$.

Esta suscetibilidade linguística ao endereçamento do Outro se torna bastante aparente no âmbito das ofensas verbais. $\mathrm{O}$ insulto atinge o corpo do ofendido de uma maneira brutal, aproximando-se, metaforicamente, da ofensa física, na medida em que inflige dor e delineia os contornos do corpo violentado ${ }^{56}$. Além disso, este ato performativo busca diminuir o ofendido, delimitar seu espaço e desabilitá-lo, privando-o de seu poder de agência. Os discursos de ódio, como os discursos racista, machista e homofóbico, utilizamse desta vulnerabilidade linguística e apropriam-se do poder discursivo para impor certas formas de existência aos grupos marginalizados, instaurando relações de hierarquia através de um ritual de subordinação que coloca o ofendido "em seu devido lugar".

Para compreender o grau de efetividade de uma ofensa, bem como seus possíveis limites, é preciso levar em consideração todo o contexto do discurso, o que nem sempre é fácil. Isso porque a ofensa não se resume àquele momento específico no qual ela é proferida, e seus efeitos extrapolam aquele instante. Segundo Butler ${ }^{57}$, a ofensa faz parte de uma convenção, um ritual no qual atos de fala anteriores e posteriores lhe dão suporte e ratificam sua força, em um

\footnotetext{
${ }^{54}$ Para ilustrar seu argumento, a autora apresenta um cenário fictício no qual alguém é chamado por um nome, e mesmo após seu protesto contra tal designação, continua sendo chamado pelo mesmo nome, ao ponto de lhe ser imposta determinada posição social, com a delineação do espaço que ocupa. Ibid. p. 33.

${ }^{55}$ Ibid. p. 2.

${ }^{56}$ Ibid. p. $4-5$.

${ }^{57}$ Ibid. p. 2-3.
} 
processo histórico de autoafirmação através da repetição. Dessa forma, o contexto discursivo da ofensa nunca poderá ser capturado em sua totalidade, visto ser impraticável conhecer plenamente os atos de fala que foram praticados no passado e, menos ainda, os que serão realizados no futuro.

Feitas essas considerações, podemos concluir que a subjugação promovida pelo discurso de ódio é um processo contínuo, que envolve a constante repetição de atos discursivos. Existe, assim, uma dimensão citacional ${ }^{58}$ no discurso ofensivo, que invoca uma convenção linguística que o precede e o sucederá. Nesta linha, é importante ter em mente que a historicidade da linguagem é incomensuravelmente maior do que a do sujeito falante, que é formado em seu interior. Deste modo, a responsabilidade do sujeito reside na repetição - e não na produção, que é coletiva - daquele discurso de ódio, o que conduz a uma renovação e a um restabelecimento do contexto opressivo ${ }^{59}$ :

Na verdade, conforme esclarecido anteriormente é impossível ter o conhecimento de toda a situação que antecede e perpassa a ofensa, pois ela é anterior ao ato de fala e continua além dele, apesar do esforço ser sempre no sentido de tentar conhecê-lo. O racismo no Brasil é anterior à injúria racista proferida no trânsito, ou no campo de futebol. Sem dúvida, nessa perspectiva é impossível atribuir a responsabilidade, considerada a partir da causa ou da origem da ofensa, a um único indivíduo. (...). Apesar de todo o ônus da ofensa não poder ser atribuído a ele, sem dúvida ele pode ser responsabilizado pela reprodução de um discurso de ódio, ou de um discurso que segrega e hierarquiza, determinando os destinos das subjetividades de acordo com identidades construídas e naturalizadas ${ }^{60}$.

O nome ofensivo carrega uma história em seu interior, a história que contém os usos dados ao termo ao longo do tempo e que, por isso, é responsável pela sedimentação de seu significado contemporâneo. A força performativa do nome, sua capacidade de ofender e subjugar, é proveniente desta história, na medida em que depende de um processo ininterrupto de repetição que opera por meio de um trauma. A cada vez que o nome é repetido,

\footnotetext{
${ }^{58}$ Butler sustenta que os discursos ofensivos são, de certo modo, citações, uma vez que reproduzem e, com isso, reforçam discursos que já existem.

${ }^{59}$ Ibid. p. 25-28, 33, 80.

${ }^{60}$ OLIVEIRA, Adriana Vidal de. Op. cit., p. 78.
} 
o trauma social é revivido, garantindo-se, assim, a manutenção das estruturas hierárquicas que permeiam a relação entre ofensor e ofendido ${ }^{61}$.

No entanto, é possível rebater estes discursos por meio de um contra discurso. Como vimos, o mesmo mecanismo responsável pela diminuição e subordinação do sujeito nomeado viabiliza sua existência social e linguística, o que, por conseguinte, instaura a possibilidade de articulação de uma resposta. Nesse sentido, se considerarmos que há uma distância temporal entre o ato de fala e a produção dos seus efeitos, veremos que surge a possibilidade de ressignificação das palavras que originalmente pretendiam ofender. $\mathrm{O}$ receptor do discurso, investido de agência linguística por esse mesmo discurso, poderá ressignificá-lo e devolvê-lo ao falante, produzindo efeitos inesperados em meio a um contexto modificado ${ }^{62}$. Dessa forma, o trauma que a linguagem carrega nunca será apagado, mas seus rumos podem ser alterados ${ }^{63}$. Isso porque a força de um performativo não decorre exclusivamente de sua capacidade de invocar e reencenar a autoridade de contextos anteriores. Essa força pode se manifestar precisamente por meio da ruptura com o contexto original e da instauração de um novo contexto ${ }^{64}$.

Nesta linha, Kimberlé Crenshaw ressalta ${ }^{65}$ a participação dos grupos subordinados no processo de nomeação, fornecendo, como exemplo, a subversão do significado da categoria "Black" promovida pelos afrodescendentes norte-americanos, que resistiram a uma subjetificação cujo único propósito era inferiorizá-los. A apropriação e a ressignificação do termo produziram como efeito inesperado o empoderamento do grupo - bem ilustrado pela famosa expressão black power -, com a consequente frustração da pretensão inicial de subjugá-los.

\footnotetext{
${ }^{61}$ BUTLER, Judith. Excitable speech: a politics of the performative. p. 36.

62 Ibid. p. 14-15.

${ }^{63}$ Ibid. p. 38.

64 Ibid. p. 145.

${ }^{65}$ CRENSHAW, Kimberlé. Mapping the Margins: Intersectionality, Identity Politics, and Violence against Women of Color. p. 1297.
} 
Nem sempre, porém, o discurso opressor opera por meio da nomeação. Muitas vezes, não dirigir a palavra, não reconhecer a pessoa nem sua história é o modo mais efetivo de atingi-la e enfraquecê-la. Sobre esse aspecto, é significativo, por exemplo, o fato de a mídia brasileira não noticiar homicídios de jovens negros e pobres, que morrem de forma sistemática em nosso país ${ }^{66}$, sobretudo se considerarmos o enfoque dado pelos meios de comunicação a furtos, roubos e homicídios de pessoas brancas da classe média. Da mesma maneira, a despreocupação das escolas em ensinar as histórias dos povos africanos e indígenas, bem como os diversos projetos de lei que vêm tentando proibir o debate a respeito do gênero em colégios ${ }^{67}$ evidenciam contextos discursivos nos quais o silêncio é o fator determinante na perpetração da lesão.

Diante disso, podemos concluir que a constituição dos sujeitos na linguagem depende, na mesma medida, dos nomes pelos quais eles nunca foram chamados, pois essa não-nomeação também delimita seu espaço de existência e de atuação possível. Além disso, a produção dos sujeitos está intrinsecamente ligada a o que Butler chama de censura implícita ${ }^{68}$ : nossa linguagem é regulada por normas explícitas e implícitas que instituem o domínio do que pode ser falado. Com isso, o sujeito inicia sua existência linguística em meio a um ambiente discursivo no qual alguns discursos e palavras são ininteligíveis, enquanto outros só podem ser pronunciados por aqueles que têm legitimidade para tal.

Contudo, o domínio do falável pode ser contestado ${ }^{69}$. Ao dizer o infalável, o sujeito expõe a instabilidade das barreiras que delimitam o campo do inteligível e, a partir daí, inicia seu progressivo deslocamento. No mesmo

\footnotetext{
66 "Aos 21 anos de idade, quando há o pico das chances de uma pessoa sofrer homicídio no Brasil, pretos e pardos possuem $147 \%$ a mais de chances de ser vitimados por homicídios, em relação a indivíduos brancos, amarelos e indígenas". Dados do IPEA, divulgados no Atlas da Violência 2016: 〈http://infogbucket.s3.amazonaws.com/arquivos/2016/03/22/atlas_da_violencia_2016.pdf >.

${ }^{67}$ Disponível em: <http://educacaointegral.org.br/reportagens/projeto-de-lei-preve-prisao-de-docenteque-falar-sobre-ideologia-de-genero/>.

${ }^{68}$ BUTLER, Judith. Op. cit., p. 41 e 133-135.

${ }^{69}$ Ibid. p. 41, 147, 157-159.
} 
sentido, falar sem autorização e apropriar-se de discursos que são privilégio de grupos dominantes abre a possibilidade de ressignificação desses mesmos discursos, que podem assumir significados nunca antes previstos. Um ato de fala ilegítimo pode desafiar as formas socialmente estabelecidas de legitimidade. Quando, por exemplo, um grupo marginalizado clama por "igualdade", "liberdade", "justiça" ou "democracia", ele se apropria de termos originalmente excludentes para criticar as posições sociais institucionalizadas e reivindicar seu direito a integrar os significados daquelas palavras, promovendo, assim, a construção de novos contextos e novas formas de legitimidade.

Neste cenário, a agência política dos grupos marginalizados não pode ser desvinculada de sua voz, de sua capacidade de apropriar-se dos discursos para ressignificar determinados contextos e ampliar o domínio do falável e do legítimo. Para isso, é necessário ocupar os espaços de fala, assumindo esta posição com autoridade, ainda que esta não tenha sido autorizada pelos poderes instituídos. Ademais, a produção do conhecimento deve ser assumida por esses grupos, pois somente assim o domínio do inteligível, regulado e restringido por grupos dominantes, poderá se tornar um terreno de disputas, sujeito a constantes reformulações. A exposição do pensamento e das experiências históricas e culturais dos grupos oprimidos inaugura novas formas de percepção, de compreensão e de significação do mundo, as quais são fundamentais para a desconstrução dos paradigmas que sustentam as atuais estruturas hierárquicas de poder. Nesta linha, podemos encontrar uma possível resposta para estas exigências políticas e epistemológicas no conceito de decolonialidade, que será abordado com maior profundidade no capítulo seguinte. 


\section{Decolonialidade e interseccionalidade}

No final do primeiro capítulo, fizemos referência, sem maiores detalhes, ao conceito de decolonialidade. Para compreendermos a fundo o significado do termo, bem como sua importância para o conceito de interseccionalidade, é preciso fazer uma breve retrospectiva histórica, seguida de uma análise das características e fundamentos do projeto decolonial. É o que faremos no tópico subsequente.

\subsection{Decolonialidade e saberes localizados}

O descobrimento da América no final do século XV marcou o início de um longo período, o colonial, cujas repercussões são visíveis, ainda hoje, em todo o mundo. É importante ter em mente que o projeto colonial europeu envolvia muito mais do que a simples exploração econômica da América Latina (ou da África e da Ásia, a depender da época e do colonizador). De acordo com uma perspectiva decolonial, este projeto inaugurou um sistema de poder mundial capitalista, o qual não pode ser reduzido a um simples sistema econômico, já que abarca processos econômicos, políticos e culturais que se entrelaçam constantemente e, a partir desta interação, constituem o referido sistema, configurando, assim, uma rede global de $\operatorname{poder}^{70}$. Esta rede, portanto, é estruturada por diversas hierarquias de poder - raciais, sexuais, de gênero, de classe, etc. - e nenhuma delas se sobrepõe ou é autônoma em relação às outras.

Feitas essas considerações, podemos dizer que a decolonialidade se distingue de outras vertentes de pensamento por duas razões principais. A

\footnotetext{
70 CASTRO-GÓMEZ, Santiago; GROSFOGUEL, Ramón. Giro decolonial, teoría crítica y pensamiento heterárquico. In: CASTRO-GÓMEZ, Santiago; GROSFOGUEL, Ramón (Org.). El giro decolonial: reflexiones para una diversidad epistémica más allá del capitalismo global. Bogotá: Siglo del Hombre Editores, 2007. p. 17.
} 
primeira delas diz respeito a uma visão complexa e não reducionista do sistema mundo. Com efeito, esta rede de poder global é composta tanto por fatores político-econômicos quanto por fatores culturais e epistêmicos, ambos indispensáveis no que tange à formação e à manutenção desse sistema. Assim, a colonialidade do poder, termo cunhado por Aníbal Quijano para se referir à "forma específica que a dominação e a exploração adquirem na constituição do sistema de poder mundial capitalista"71 depende fundamentalmente da colonialidade do saber - controle e colonização da produção do conhecimento - e da colonialidade do ser - controle e colonização das subjetividades. Com isso, torna-se muito mais fácil perceber o papel determinante da linguagem nesse sistema: a divisão internacional do trabalho, que aloca os trabalhos mais coercitivos e mal remunerados às raças ditas inferiores, é um efeito dos discursos raciais que influenciam nossas percepções a respeito da realidade, regulam e disciplinam nossos comportamentos e formam nossas subjetividades $^{72}$. Da mesma forma, os discursos sexistas e homofóbicos sustentam a binariedade do gênero e a heterossexualidade compulsória, que formam as bases do modelo de família mononuclear cristã, instituição estruturante do capitalismo contemporâneo, visto que garante e perpetua a divisão sexual do trabalho, com a consequente exploração do trabalho das mulheres, que recebem os menores salários e não são remuneradas por suas tarefas domésticas.

Além disso, a decolonialidade se diferencia de outras formulações teóricas por um segundo motivo: para ela, a descolonização dos países que adquiriram sua independência jurídico-política foi parcial, na medida em que as colonialidades do poder, do saber e do ser continuam em operação. Desta maneira, a subordinação econômica e epistemológica das periferias em relação aos centros - ou do Sul em relação ao Norte - e as relações de poder do

\footnotetext{
${ }^{71}$ LUGONES, María. Rumo a um feminismo descolonial. Estudos Feministas, Florianópolis, v. 22, n. 3, p. 939, jan. 2015.

${ }^{72}$ CASTRO-GÓMEZ, Santiago; GROSFOGUEL, Ramón. Op. cit. p. 16-17.
} 
sistema mundo permanecem intactas, ainda que tenham sido ressignificadas no contexto pós-moderno, no âmbito do capitalismo global contemporâneo. Por conta disso, é preciso lutar por uma nova descolonização capaz de desestabilizar as hierarquias geopolíticas, raciais, étnicas, sexuais, econômicas, epistêmicas e de gênero ${ }^{73}$. Neste particular, tanto os discursos desenvolvimentistas quanto os neoliberais se tornam um obstáculo a essa descolonização, uma vez que ambos colocam a Europa e os Estados Unidos representativos do Ocidente - como modelos de civilização e de desenvolvimento, enquanto enfatizam o status subdesenvolvido e pré-moderno das periferias, que devem perseguir aquele modelo. Este olhar eurocentrado das elites dos países do chamado Terceiro Mundo contribui para a reprodução, nestas nações, da colonialidade, mediante a permissão de intervenções econômicas e ideológicas efetuadas por instituições do capitalismo global, como o Fundo Monetário Internacional e o Banco Mundial.

Mas, afinal, como se deu o processo de formação do sistema de poder mundial capitalista? A matriz colonial de poder, como a denomina Walter Mignolo $^{74}$, tinha como objetivo uma dominação tão profunda dos povos colonizados que todos os aspectos de suas vidas, materiais e imateriais, foram afetados. O projeto expansionista europeu tinha como seus pilares fundantes: o controle da economia, com a apropriação de terras e recursos naturais, bem como a exploração do trabalho; o controle da autoridade, através da imposição de um governo apoiado por instituições políticas e forças militares; o controle do conhecimento, por meio do que Mignolo chama de privilégio epistêmico da modernidade ${ }^{75}$; e, por fim, o controle da subjetividade, o que envolveu a regulação do gênero e da sexualidade.

\footnotetext{
73 Ibid. p. 13-14 e 17.

${ }^{74}$ MIGNOLO, Walter. La idea de América Latina (la derecha, la izquierda y la opción decolonial). Crítica y Emancipación, (2): p. 254, primer semestre 2009.

75 Ibid. p. 260.
} 
Em "La idea de América Latina (la derecha, la izquierda y la opción decolonial)", Mignolo ressalta ${ }^{76}$ a importância dos dois últimos pilares, o controle do conhecimento e da subjetividade, na efetivação dos dois primeiros e, consequentemente, na manutenção da matriz colonial de poder. Ao determinar a única maneira correta de se ler a realidade, o europeu pôde controlar os corpos dos colonizados, assim como sua forma de ser, pensar e agir. As chamadas colonialidade do saber e colonialidade do ser impuseram aos colonizados uma existência definida em termos eurocêntricos e tornaram possível a plena realização do projeto colonial.

Como, porém, essas colonialidades foram implementadas e qual foi a sua justificativa? María Lugones explica que a modernidade - que, na perspectiva decolonial, começa a adquirir o status de paradigma nessa mesma época - nega a existência de outras formas de viver e de pensar o mundo. Todo e qualquer raciocínio cujas premissas ontológicas e epistemológicas diferem das do pensamento moderno é inválido e, por isso, deve ser corrigido/eliminado. Não há espaço para a coexistência e a multiplicidade de cosmovisões. Assim, essa negação monopolista teve como reflexo imediato a colonialidade, que "emerge como constitutiva da modernidade. A diferença entre moderno e não moderno torna-se - na perspectiva moderna - uma diferença colonial, uma relação hierárquica na qual o não moderno está subordinado ao moderno"77.

A partir daí, iniciou-se o projeto de destruir o colonizado, sua memória - por meio de políticas de esquecimento -, suas práticas e costumes, seus saberes, sua linguagem e suas instituições. Num primeiro momento, esse genocídio cultural tem como fundamento a conversão dos bárbaros ao cristianismo. Posteriormente, com a secularização do pensamento moderno, o argumento intervencionista se modifica, mas a lógica permanece a mesma: a

\footnotetext{
${ }^{76}$ Ibid. p. 251-276.

${ }^{77}$ LUGONES, María. Op. cit., p. 943.
} 
Europa tem a pretensão de civilizar o selvagem. Para embasar o projeto, surgem as categorias dicotômicas hierárquicas, construídas pelo pensamento moderno colonial. Nesse sentido, a dicotomia entre o humano e o não-humano - intrinsecamente ligada à dicotomia branco/não branco, não obstante o conceito de raça ter sido formulado apenas nos séculos seguintes - inaugurou uma relação hierárquica entre colonizador e colonizado - seja ele o índio americano ou o africano escravizado -, na qual aquele assumia uma missão civilizatória perante os povos ditos primitivos. Na prática, essa desumanização serviu para que os europeus perpetrassem, sem qualquer peso de consciência, violências e abusos incalculáveis contra os povos conquistados.

A matriz colonial de poder tinha como objetivo apagar todo o passado do colonizado para transformá-lo em um não-ser, desumanizado e inferiorizado, e instituir novos parâmetros epistemológicos, ontológicos, linguísticos e sociais, responsáveis pela regulação de seus comportamentos e de suas relações. À medida que as colonialidades do saber e do ser avançavam, o colonizado passava, cada vez mais, a olhar para si mesmo através dos olhos do colonizador e a internalizar as dicotomias hierárquicas da modernidade, cujo viés epistêmico é notadamente racista, classista, heteronormativo e patriarcal.

Mas as culturas dos povos colonizados nunca foram destruídas por completo ou de modo permanente. Com efeito, se identificarmos as colonialidades do saber e do ser como um processo histórico de subjetificação, veremos que a matriz colonial de poder renova-se constantemente, reproduzindo e readequando seus mecanismos de controle aos novos contextos. Ao mesmo tempo, os povos colonizados nunca aceitaram o domínio europeu de modo passivo, visto que resistiram/resistem para manter uma subjetividade ativa e para romper com a hegemonia do pensamento moderno: “A resistência é a tensão entre a sujeitificação (a formação/informação do sujeito) e a subjetividade ativa, aquela noção mínima de agenciamento 
necessária para que a relação opressão $\leftarrow \rightarrow$ resistência seja uma relação ativa" $" 78$.

Esta relação entre opressão e resistência pode ser melhor compreendida a partir da noção de diferença colonial, interpretada por Mignolo como o espaço físico e imaginário no qual a cultura moderna eurocentrada é absorvida, adaptada, rejeitada e confrontada pela cultura local, numa disputa que colocará o colonizado numa posição de fronteira entre os dois mundos ${ }^{79}$. A diferença colonial viabiliza a formação de um pensamento de fronteira, uma epistemologia contra-hegemônica criada a partir da perspectiva do subalterno, que possibilita, enfim, a mobilização de um discurso de resistência: " $A$ diferença colonial cria as condições para situações dialógicas nas quais uma enunciação fraturada é mobilizada pela perspectiva subalterna como resposta ao discurso e perspectiva hegemônicas" $"$.

Neste ponto, a teoria de Butler a respeito da linguagem pode ser bastante elucidativa. Como vimos, a autora enfatiza a forma pela qual os sujeitos são violentamente constituídos através da interpelação do outro. No entanto, essa mesma interpelação se torna, paradoxalmente, a condição de possibilidade para a produção de uma contra resposta àquele discurso, pois é ela que inaugura a existência linguística do sujeito nomeado e, por conseguinte, sua agência discursiva. Da mesma maneira, a matriz colonial de poder operou por meio de um discurso violento com vistas a produzir uma nova realidade ao colonizado, que se viu numa posição brutalizada e desumanizada imposta pelo colonizador, o qual, supostamente, seria superior por natureza. Nesse sentido, os ideais e referências do que é bom, correto e desejável eram exclusivamente eurocêntricos.

\footnotetext{
${ }^{78}$ Ibid. p. 940.

${ }^{79}$ Ibid. p. $945-946$.

${ }^{80}$ MIGNOLO, Walter D. Local Histories/Global Designs: Coloniality, Subaltern Knowledges and Border Thinking. Princeton: Princeton University Press, 2000. p. x apud LUGONES, María. Op. cit., p. 947.
} 
Contudo, a matriz colonial de poder não foi capaz de perceber que, ao criar a figura do subordinado, ela, ao mesmo tempo, instituiu uma nova forma de pensar, existir e resistir completamente diferente do pensamento hegemônico colonial/moderno, mas que, de forma alguma, está fora dele, uma vez que se situa em suas margens. A intensa opressão sofrida pelos povos colonizados não conduziu a um extermínio de suas culturas e a uma plena absorção das concepções de vida modernas, mas sim a uma situação de mútua influência e constituição - tanto pela modernidade quanto pela cultura local bastante particular, responsável pelo surgimento de um pensamento de fronteira, que servirá de guia na articulação dos discursos de resistência: " $O$ pensamento de fronteira [...] é uma consequência lógica da diferença colonial. [...] [O] lócus fraturado de enunciação a partir da perspectiva subalterna define o pensamento de fronteira como resposta à diferença colonial"\$1.

O pensamento fronteiriço nada mais é do que a "resposta epistêmica dos subalternos ao projeto eurocêntrico da modernidade" 82 , é a emergência de um conhecimento localizado capaz de combater as colonialidades do saber e do ser, o que, por sua vez, desestabilizará a colonialidade do poder. Este é o projeto decolonial, que tem como um de seus objetivos a reapropriação, pelos colonizados, de seu direito epistêmico e de seu espaço de fala que, durante séculos, lhes foram negados em razão do privilégio epistêmico da modernidade ${ }^{83}$.

A chave para a realização do projeto decolonial é o pensamento de fronteira, cuja característica principal é o reconhecimento do papel do lócus enunciativo - neste caso, a fronteira na qual opera a diferença colonial - na produção do conhecimento. É dizer: o pensamento é produzido a partir de um saber localizado, isto é, a partir de perspectivas parciais e de experiências

\footnotetext{
${ }^{81}$ Ibid. p. 947.

82 BERNARDINO-COSTA, Joaze; GROSFOGUEL, Ramón. Decolonialidade e perspectiva negra. Soc. Estado, Brasília, v. 31, n. 1, p. 19, abr. 2016.

${ }^{83}$ MIGNOLO, Walter. La idea de América Latina (la derecha, la izquierda y la opción decolonial). p. 261.
} 
situadas. Como contraponto ao paradigma hegemônico da modernidade, que se coloca como um saber neutro, objetivo e universal, o projeto decolonial enfatiza a relação inseparável entre lugar e pensamento:

Afirmar o locus de enunciação significa ir na contramão dos paradigmas eurocêntricos hegemônicos que, mesmo falando de uma localização particular, assumiram-se como universais, desinteressados e não situados. O locus de enunciação não é marcado unicamente por nossa localização geopolítica dentro do sistema mundial moderno/colonial, mas é também marcado pelas hierarquias raciais, de classe, gênero, sexuais etc. que incidem sobre o corpo ${ }^{84}$.

Neste contexto, o olhar feminista de Donna Haraway sobre a ciência tem muito a contribuir para o projeto decolonial. Em "Saberes localizados: a questão da ciência para o feminismo e o privilégio da perspectiva parcial" ${ }^{\text {, }}$, a autora explica que nossa percepção está associada ao modo como vivemos e pensamos, ou seja, ao nosso olhar corporificado e localizado. Cada corpo produz formas muito específicas de ver e de interpretar a realidade, que variam de acordo com experiências, aprendizados, interesses e necessidades, os quais se desenvolveram no interior desta realidade e em razão dela, bem como estão intrinsecamente conectados com as estruturas e relações de poder que envolvem esses corpos. Por conta disso, a suposta separação entre sujeito e objeto não existe, e a passividade deste último é um mito. Com efeito, as traduções que fazemos do mundo e o conhecimento que produzimos a partir delas são influenciados pela posição que ocupamos neste mesmo mundo.

Da mesma forma, nossas interpretações e traduções estão carregadas de poder constitutivo. Como vimos no capítulo 1, a pretensão descritiva da linguagem é uma falácia. Isto posto, não há como negar nossa percepção ativa, que constrói a realidade que afirma simplesmente ver e retratar. Por isso, o sujeito que produz determinado conhecimento deveria poder ser responsabilizado, isto é, avaliado criticamente por outro saber localizado e chamado a prestar contas. Contudo, o paradigma moderno aposta em um saber descorporificado que está para além da responsabilização. É dizer: a crença na

\footnotetext{
${ }^{84}$ BERNARDINO-COSTA, Joaze; GROSFOGUEL, Ramón. Op. cit., p. 19.

${ }^{85}$ HARAWAY, Donna. Op. Cit., p. 7-41.
} 
transcendência da visão - "não estar em nenhum lugar ao mesmo tempo que se alega ver tudo"86 - e no distanciamento entre sujeito e objeto afasta a responsabilidade daquele ao ocultar a mútua influência presente na relação entre os dois.

A teoria epistemológica a respeito da objetividade do olhar científico presume que aquele que vê tem uma visão neutra, plena e universal, capaz de enxergar tudo e todos ao mesmo tempo em que não está em lugar nenhum - ou seja, sua neutralidade não está comprometida por nenhum interesse particular e localizado. Para que isso seja possível, este olhar é descorporificado, com a consequente negação, em razão desta transcendência, de sua parcialidade e de seu posicionamento específico. À vista dessas exigências metodológicas e epistemológicas, quem estaria mais apto a ocupar este não-lugar do que o Homem Branco, aquele sujeito considerado universal, tanto em termos de gênero, quanto em termos de raça, e que, por isso, poderia representar com tranquilidade o Humano?

Esta descorporificação do olhar do homem branco como pressuposto metodológico para a produção do conhecimento científico está associada a um longo processo histórico europeu de separação entre o corpo e o não-corpo ${ }^{87}$ o que hoje chamaríamos de mente - que tem sua origem na antiga crença cristã a respeito da primazia da alma sobre o corpo. Esta hierarquia adquire contornos inteiramente novos quando Descartes estabelece que a razão, atributo do sujeito racional - identidade que surge neste momento -, localizase exclusivamente na "alma" e, portanto, está separada do corpo, o qual, por sua vez, é incapaz de raciocinar e, por isso, não pode ser nada além de um objeto do conhecimento. É pertinente notar que, durante o processo de consolidação deste paradigma no pensamento eurocêntrico moderno, este

\footnotetext{
${ }^{86}$ Ibid. p. 23.

${ }^{87}$ QUIJANO, Aníbal. Colonialidade do poder, eurocentrismo e América Latina. In: A colonialidade do saber: eurocentrismo e ciências sociais. LANDER, Edgardo (Org.). Buenos Aires: Conselho Latinoamericano de Ciências Sociais - CLACSO, 2005. p. 117-118.
} 
dualismo hierárquico entre mente/razão/sujeito e corpo/natureza/objeto é formulado no sentido de que a razão deve não só conhecer a natureza, mas também explorá-la e dominá-la.

Diante disso, não é difícil perceber que a construção do sujeito racional descorporificado foi muito útil aos interesses colonialistas europeus. Nos séculos XVIII e XIX, muitas das teorias "científicas" a respeito das raças foram desenvolvidas com base nesta cisão entre corpo e razão. Segundo essas teorias, as raças colonizadas eram destituídas de razão, o que evidenciava sua inferioridade racial. Enquanto corpos não racionais, esses não-sujeitos estavam muito mais próximos da natureza do que as pessoas brancas, e como tais, deviam ser objeto de conhecimento, dominação e exploração. Há de se acrescentar que, além da opressão racial, também a opressão sexual foi facilitada por esse pensamento. A associação da mulher com a natureza e com o corpo - distanciado da capacidade de raciocinar - colocou-a na posição do objeto que deve ser dominado, o que sustentou a apropriação e a exploração de seus corpos e de seu trabalho. A perversidade de toda essa lógica atinge seu ponto mais alto quando analisamos a situação das mulheres não brancas: sua objetificação, tanto por ser mulher, como por pertencer a uma raça dita inferior - e quanto maior a inferioridade, mais próxima da natureza ela estará ${ }^{88}$ - a sujeita a formas intensas de exploração e dominação.

No entanto, ao constatarmos que a posição do homem branco - único sujeito racional descorporificado - é, na verdade, marcada pela masculinidade e pela branquitude, ou seja, que seu lugar de produção do conhecimento é tão particular quanto o de qualquer outra pessoa, podemos começar a desmistificar a crença na objetividade desinteressada do conhecimento científico e concluir, a partir daí, que a suposta universalidade do homem branco serve ao único propósito de igualar - no sentido mais forte da palavra - este sujeito específico

\footnotetext{
88 “Algumas raças - negros (ou africanos), índios, oliváceos, amarelos (ou asiáticos) e nessa sequência - estão mais próximas da "natureza" que os brancos". Ibid. p. 118.
} 
ao Humano com " $H$ " maiúsculo, de modo que ele passe a personificar a imagem do único humano possível, com a consequente invisibilização - ou, o que seria mais apropriado em alguns contextos, desumanização - de todos os outros $^{89}$. Esta estratégia inquestionavelmente política, posto que interessada no monopólio da produção do conhecimento como forma de dominação, quando exposta desta maneira, afasta qualquer pretensão de objetividade da ciência. Não obstante, ao invés de abandonarmos o termo, podemos ressignificá-lo, em atenção à proposta inovadora apresentada por Donna Haraway:

Gostaria de continuar apoiando-me metaforicamente num sistema sensorial muito difamado no discurso feminista: a visão. A visão pode ser útil para evitar oposições binárias. Gostaria de insistir na natureza corpórea de toda visão e assim resgatar o sistema sensorial que tem sido utilizado para significar um salto para fora do corpo marcado, para um olhar conquistador que não vem de lugar nenhum. Este é o olhar que inscreve miticamente todos os corpos marcados, que possibilita à categoria não marcada alegar ter o poder de ver sem ser vista, de representar, escapando à representação. Este olhar significa as posições não marcadas de Homem e Branco, uma das várias tonalidades desagradáveis que a palavra objetividade tem para os ouvidos feministas nas sociedades científicas e tecnológicas, pós-industriais, militarizadas, racistas e dominadas pelos homens, isto é, aqui, na barriga do monstro, nos Estados Unidos no final dos anos 80. Gostaria de uma doutrina de objetividade corporificada que acomodasse os projetos científicos feministas críticos e paradoxais: objetividade feminista significa, simplesmente, saberes localizados. ${ }^{90}$

Esta objetividade corporificada será atingida por meio do diálogo, pautado tanto pelo conflito quanto pela solidariedade: " $O$ conhecimento racional é uma conversa sensível ao poder"'91. A ciência não está acima das disputas políticas, ela é o campo no qual os significados e as traduções do mundo serão contestados e as interpretações da realidade, sempre críticas e parciais, serão questionadas, responsabilizadas, reformuladas ou

\footnotetext{
${ }^{89}$ Esta é uma lição importante para aqueles que veem com bons olhos os discursos universalizantes, como o discurso dos Direitos Humanos. Não há nada de inclusivo nestes discursos. Ao contrário, a tentativa mais inocente de generalizar para incluir - e, com isso, não estou dizendo que o discurso dos direitos humanos foi originalmente pensado para ser inclusivo ou que, atualmente, este tipo de raciocínio seja a regra - pode revelar-se extremamente excludente, pois nem sempre contamos com nossa tendência viciada de pensar de forma bastante específica quando tentamos generalizar. Não podemos esquecer: o sujeito universal tem um rosto. Este rosto é branco e masculino.

${ }^{90}$ HARAWAY, Donna. Op. cit., p. 18.

${ }^{91}$ Ibid. p. 33.
} 
complementadas, num contexto conscientemente político. Nenhuma forma de saber, incluindo os saberes subjugados, está isenta de uma avaliação crítica. Por isso que, no combate a qualquer visão totalitária de mundo e na busca da formulação de um conhecimento objetivo, torna-se imprescindível enfatizar a parcialidade do sujeito falante:

Estou argumentando a favor de políticas e epistemologias de alocação, posicionamento e situação nas quais parcialidade e não universalidade é a condição de ser ouvido nas propostas a fazer de conhecimento racional. São propostas a respeito da vida das pessoas; a visão desde um corpo, sempre um corpo complexo, contraditório, estruturante e estruturado, versus a visão de cima, de lugar nenhum, do simplismo. ${ }^{92}$

Ao reconhecer a parcialidade de sua visão, o sujeito admite, ao mesmo tempo, que existem outras maneiras igualmente válidas de se posicionar, ou seja, reconhece a multiplicidade de sujeitos e de perspectivas. A afirmação desta multiplicidade é um pressuposto indispensável do diálogo. Por outro lado, é pertinente salientar que a multiplicidade interna de cada sujeito não é um fator menos importante na efetivação de um diálogo.

Sobre este aspecto, há de se destacar que, por serem socialmente construídos, os indivíduos não possuem uma identidade pronta e acabada, unívoca e coerente. Muito pelo contrário. O processo contínuo e inacabado de formação discursiva dos sujeitos é extremamente complexo, envolvendo um sem número de discursos que interagem entre si de múltiplas maneiras, o que se reflete na subjetividade, que é multidimensional e contraditória. Curiosamente, essa heterogeneidade interna, somada ao amplo potencial transformativo da subjetividade, é a condição de possibilidade do diálogo, pois, desta forma, o eu cognoscente é capaz de modificar sua posição, e de ouvir, entender e enxergar como o outro, sem precisar ser o outro:

A topografia da subjetividade é multidimensional bem como, portanto, a visão. $\mathrm{O}$ eu cognoscente é parcial em todas suas formas, nunca acabado, completo, dado ou original; é sempre construído e alinhavado de maneira imperfeita e, portanto, capaz de juntar-se a outro, de ver junto sem pretender ser outro. Eis aqui a promessa de

${ }^{92}$ Ibid. p. 30. 
objetividade: um conhecedor científico não procura a posição de identidade com o objeto, mas de objetividade, isto é, de conexão parcial. ${ }^{93}$

Além disso, é crucial que se firme um diálogo entre o sujeito e seu objeto de estudo, o mundo ${ }^{94}$, que há muito vem sendo tratado pela ciência moderna como um objeto passivo, uma simples matéria estática, um mero recurso a ser apropriado e utilizado pelo "conhecedor humano". Esta relação autoritária abre espaço para erros e abusos, bem como reaproxima o conhecimento daquela visão hegemônica de mundo - da qual divergimos diametralmente - que, no lugar de conhecê-lo, impõe-se sobre ele. Para não trilharmos este caminho novamente, a proposta de Haraway ${ }^{95}$ emerge como uma alternativa acolhedora: ao enxergarmos o mundo como um agente complexo, um sujeito ativo capaz de interagir, dialogar e participar da própria constituição de nossa subjetividade, trazemos uma dinamicidade desestabilizadora muito bem-vinda à produção do conhecimento, que não fica restrita à compreensão limitada e enviesada do conhecedor.

Feitas essas considerações, podemos perceber que a ciência moderna e sua suposta objetividade na produção do conhecimento têm um papel extremamente relevante no sistema moderno colonial capitalista. Os povos colonizados, relegados à condição de objetos passivos de estudo, foram destituídos de seu direito de produzir conhecimento e, por conseguinte, de seu direito de criticar e responsabilizar o conhecimento produzido pelos europeus. Estes, por sua vez, ao se colocarem numa posição descorporificada, neutra e universal, distanciando-se de seus objetos de estudo, não podiam ser responsabilizados pelas consequências catastróficas advindas do seu conhecimento.

\footnotetext{
${ }^{93}$ Ibid. p. 26.

${ }^{94}$ Quando digo mundo, estou me referindo a qualquer objeto de estudo, seja ele uma espécie de planta, uma espécie de animal, um ecossistema, uma cidade, região ou país, uma comunidade de indígenas, uma categoria - como o gênero -, e assim por diante. Isso significa que não apenas as ciências humanas e sociais devem reconhecer a agência de seus objetos de estudo, mas também as ciências da natureza.

${ }^{95}$ Ibid. p. 35-38.
} 
Em contrapartida, o projeto decolonial reconhece a agência dos povos colonizados, garantindo seu direito epistêmico e seu espaço de fala, de modo que eles possam narrar suas histórias em termos não eurocêntricos, enfatizando a todo o momento seu papel como protagonistas de suas histórias e como sujeitos ativos. Neste cenário, será um desafio produzir novos significados e novas compreensões da realidade, visto que as fronteiras do inteligível são delimitadas pela linguagem hegemônica do ocidente. No entanto, justamente por ocuparem o entre-lugar do pensamento de fronteira, os povos colonizados são plenamente capazes de transpor este obstáculo e, a partir da produção de um saber localizado neste lócus fraturado, redefinir - isto é, ampliar - o campo do inteligível ${ }^{96}$.

Para tanto, é de crucial importância reconhecer a parcialidade como pressusposto metodológico e epistemológico da produção do conhecimento. Isso porque qualquer visão universalizante de mundo é autoritária e excludente - e, com isso, restringe o campo do inteligível. Em seu lugar, a opção decolonial busca reconhecer a diversidade do mundo e das histórias locais transformadas pela matriz colonial de poder, o que Mignolo chama de pluriversalidade $^{97}$. São muitas e variadas as estratégias de resistência contra essa matriz. Precisamos de todas elas para derrubar definitivamente a hegemonia do pensamento ocidental e, sobretudo, para construir um novo paradigma, pautado pela multiplicidade de cosmovisões. Daí a premente necessidade de que os numerosos saberes localizados e perspectivas parciais se conectem por meio da

\footnotetext{
${ }^{96}$ A propósito, podemos citar duas autoras emblemáticas que se utilizam desse espaço de fronteira para ressignificar a linguagem e produzir um discurso em outros termos: Lélia Gonzalez, que evidenciou e praticou em seus textos, por meio de uma escrita que resgata e enfatiza - as inúmeras marcas e contribuições da africanidade na cultura brasileira, incluindo as marcas linguísticas, razão pela qual nós, brasileiros, ainda que de forma inconsciente, falamos o pretuguês; e Glória Anzaldúa, uma norteamericana descendente de mexicanos criada em uma região fronteiriça entre México e Estados Unidos, que adota o espanhol chicano - uma mistura entre o espanhol e o inglês - como a língua que a representa e que lhe permite se expressar em seus próprios termos. CARDOSO, Cláudia Pons. Amefricanizando o feminismo: o pensamento de Lélia Gonzalez. Estudos Feministas, Florianópolis, v. 22, n. 3, p. 966-967, jan. 2015.

${ }^{97}$ MIGNOLO, Walter. Op. cit., p. 269.
} 
instauração de um diálogo ininterrupto que busque soluções para os diversos sistemas de opressão contidos na matriz colonial de poder.

Nesta linha, Maria Lugones afirma ${ }^{98}$ que não é possível resistir sozinho à colonialidade do gênero. Toda resistência se dá em meio a um modo de ser, viver e pensar compartilhado. O indivíduo é fruto de práticas, hábitos, crenças e valores produzidos pela comunidade, o que significa que, quando ele age, ele não o faz de forma isolada. Além disso, a autora ressalta a imprescindibilidade do conhecimento das experiências de resistência dos(as) outros(as). Existem diversas respostas à colonialidade do gênero, na medida em que são muitas as diferenças coloniais. De fato, não foi apenas uma cultura que foi submetida à matriz colonial de poder, posto que, a partir dos projetos coloniais de dominação, instaurou-se um sistema mundial de poder capitalista. Ademais, no interior de uma mesma cultura, o habitar a diferença colonial está longe de ser uma experiência homogênea. Dito isso, é importante frisar que essa multiplicidade nunca deve ser ocultada, reduzida ou controlada, pois, caso contrário, estaríamos operando nos termos da colonialidade. Com efeito, precisamos dessa multiplicidade, sem a qual estaremos fadados à rigidez e à estagnação da colonialidade do gênero. Ao aprendermos com as experiências umas das outras, nos será aberto um universo de possibilidades de atuação criativa. Portanto, nossa força está na coalizão, na união que reconhece as diferenças, ao mesmo tempo em que não cria dicotomias entre elas: "A lógica da coalizão é desafiadora da lógica das dicotomias; as diferenças nunca são vistas em termos dicotômicos, mas a lógica tem como sua oposição a lógica de poder. A multiplicidade nunca é reduzida"99.

Por todo o exposto, seguindo o exemplo de muitas mulheres latinoamericanas, sobretudo as amefricanas - no vocabulário de Lélia Gonzalez ${ }^{100}$

\footnotetext{
${ }^{98}$ LUGONES, María. Op. cit., p. 949-950.

${ }^{99}$ Ibid. p. 950.

100 GONZALEZ, Lélia. A categoria político-cultural de amefricanidade. Tempo Brasileiro. Rio de Janeiro, no 92/93, p. 69-82, jan./jun. 1988.
} 
e ameríndias, este trabalho assume o compromisso de descolonizar o feminismo brasileiro, cujo viés eurocêntrico tende a universalizar as experiências das mulheres, o que conduz a um apagamento das múltiplas realidades vividas por mulheres sujeitas a duas ou mais formas de opressão. Para tanto, o conceito de interseccionalidade será retomado no tópico seguinte, com um enfoque especial na articulação entre gênero e raça no intuito de assegurar uma compreensão mais profunda da sociedade brasileira, atenta às suas complexas estruturas de poder, hierarquias e desigualdades sociais, e comprometida com a investigação das experiências particulares das mulheres negras $^{101}$.

\subsection{Gênero, sexualidade, raça e classe no contexto brasileiro: repensando o conceito de interseccionalidade a partir de uma perspectiva decolonial}

A sociedade brasileira contemporânea - suas instituições sociais, políticas e econômicas - é estruturada por diversos sistemas de dominação que não apenas formam identidades como também informam as maneiras pelas quais as relações sociais e de poder se dão. Partindo desta premissa, observa-se que uma investigação minimamente comprometida com um exame adequado do contexto sócio-político brasileiro deve incluir em suas considerações, como um dos pontos centrais da discussão, o racismo, componente estrutural de nossa sociedade hierarquizada. Diante desta imperiosa exigência epistemológica, iniciaremos a presente análise com a definição de racismo proposta por Ramon Grosfoguel:

Racismo é uma hierarquia global de superioridade e inferioridade ao longo da linha do humano, que vem sendo politica, cultural e economicamente produzida e

\footnotetext{
101 Infelizmente, tendo em vista o escopo limitado deste trabalho, não será possível promover uma análise adequada da realidade das mulheres indígenas do Brasil, o que não significa que esta tarefa seja menos importante.
} 
reproduzida por séculos pelas instituições do sistema mundial moderno/colonial eurocentrado/cristão-centrado capitalista/patriarcal ${ }^{102}$.

Segundo o autor, o racismo separa aqueles que estão acima da linha do humano - zona do ser -, isto é, aqueles que são plenamente reconhecidos em sua humanidade, daqueles que estão abaixo desta linha - zona do não ser, no vocabulário de Fanon ${ }^{103}$ - considerados não-humanos ou sub-humanos. A zona do ser garante aos seus integrantes o gozo de direitos, o acesso a recursos materiais e o reconhecimento social de suas subjetividades, epistemologias e espiritualidades, todos os quais são negados na zona do não ser.

Esta definição de racismo pode ser aplicada a uma multiplicidade de cenários histórico-políticos com marcadores raciais distintos. Dessa forma, além da cor, também a etnia, a língua, a cultura e a religião podem ser fatores determinantes na racialização dos corpos. Sendo assim, o marcador racial, qualquer que seja, irá racializar certos corpos como superiores e outros como inferiores, assegurando àqueles o privilégio de raça e impondo a estes a opressão racial. Por conta disso, os inúmeros sistemas de dominação que operam no interior da zona do ser - que, afinal, é um campo heterogêneo, na medida em que abarca opressões por gênero, classe, orientação sexual e outros - são sempre mitigados pelo privilégio racial daqueles que têm sua humanidade reconhecida pelo dominador. Isso porque os conflitos na zona do ser são resolvidos, em regra, por meio de mecanismos legais e políticos de regulação, uma vez que aos grupos oprimidos humanos é assegurada a aplicação do Direito e de suas leis. Por outro lado, esses mesmos sistemas de

\footnotetext{
102 Tradução nossa: "Racism is a global hierarchy of superiority and inferiority along the line of the human that have been politically, culturally and economically produced and reproduced for centuries by the institutions of the "capitalist/patriarchal western-centric/Christian-centric modern/colonial world- system" (Grosfoguel, 2011)". GROSFOGUEL, Ramon. What is Racism? Journal of WorldSystems Research, [S.1.], v. 22, n. 1, p. 10, mar. 2016.

${ }^{103}$ Em seu livro "Pele negra, máscaras brancas", Frantz Fanon utiliza a expressão "zona de não-ser" para se referir à região árida e estéril ocupada pelo negro, que não é reconhecido como ser-humano. Em seguida, alguns filósofos influenciados pelo pensamento de Fanon passaram a usar as expressões "zona do ser" e "zona do não ser" para diferenciar as experiências e posições das raças privilegiadas e das raças oprimidas, respectivamente. Ibid. p. 11. FRANTZ, Fanon. Pele negra, máscaras brancas. Salvador: EDUFBA, 2008. p. 26.
} 
dominação, quando funcionam no interior da zona do não ser - igualmente heterogênea -, são agravados, sujeitando aqueles que são vistos como nãohumanos a opressões ainda mais intensas. Neste terreno ignorado pelas instituições legais, os conflitos são resolvidos mediante a perpetração de violências e a apropriação/expropriação de seus integrantes ${ }^{104}$.

O racismo, conforme o conhecemos hoje - institucionalizado e estruturante da nossa sociedade -, começou a ter seus primeiros contornos já no início do período colonial, ainda que o conceito específico de raça - que, por meio das teorias "científicas" raciais, enfim naturalizou a hierarquia entre os povos a partir da ideia de diferenças biológicas, isto é, genéticas e fenotípicas, que determinariam as características culturais, morais e intelectuais de cada grupo racializado - só fosse elaborado posteriormente. Os conquistadores europeus - no caso do Brasil, os portugueses -, visando à exploração econômica dos conquistados, justificaram seus métodos violentos de dominação através da crença na inferioridade dos colonizados, que adquiriram, a partir daí, uma nova identidade racial. Formava-se, em meio a este cenário peculiar, o que Aníbal Quijano ${ }^{105}$ chama de novo padrão global de controle do trabalho, elemento indispensável do também novo padrão de poder mundial, o capitalismo colonial moderno, controlado por uma região que surge neste momento como uma nova identidade geocultural: a Europa Ocidental ${ }^{106}$. Assim, as diversas formas de controle do trabalho nas colônias ibéricas -

${ }^{104}$ GROSFOGUEL, Ramon. Op. cit. p. 11-14.

105 QUIJANO, Aníbal. Op. cit., p. 108-109.

106 "A primeira identidade geocultural moderna e mundial foi a América. A Europa foi a segunda e foi constituída como consequência da América, não o inverso. A constituição da Europa como nova entidade/identidade histórica fez-se possível, em primeiro lugar, com o trabalho gratuito dos índios, negros e mestiços da América, com sua avançada tecnologia na mineração e na agricultura, e com seus respectivos produtos, o ouro, a prata, a batata, o tomate, o tabaco, etc., etc. (Viola e Margolis, 1991). Porque foi sobre essa base que se configurou uma região como sede do controle das rotas atlânticas, por sua vez convertidas, precisamente sobre essa mesma base, nas rotas decisivas do mercado mundial. Essa região não tardou em emergir como Europa. América e Europa produziram-se historicamente, assim, mutuamente, como as duas primeiras novas identidades geoculturais do mundo moderno". Ibid. p. 116. 
escravidão, servidão, pequena produção mercantil, reciprocidade ${ }^{107}$ e salário estavam voltadas para a produção de mercadorias para o mercado mundial, em atenção aos recém-surgidos interesses do capital, eixo articulador das relações de produção que estava - e, em grande medida, ainda está - concentrado na Europa.

As formas de controle do trabalho nas colônias eram marcadas por uma sistemática divisão racial do trabalho e tinham como pressuposto a não remuneração das raças ditas inferiores. Na América Latina, enquanto os(as) negros(as) africanos(as) estavam sujeitos(as) ao trabalho escravo, aos(às) indígenas americanos(as) impunha-se a servidão e, por vezes, permitia-se a reciprocidade - desde que controlada e explorada pelos europeus -. A seguir, veremos que, na zona do não ser, a divisão sexual do trabalho estava subordinada à questão racial, pois, em alguns contextos, homens e mulheres escravizados eram equiparados para fins de exploração de sua força de trabalho. Por outro lado, homens brancos de classe baixa eram comerciantes, pequenos produtores ou trabalhadores assalariados, já que os cargos de administração colonial eram reservados aos europeus de origem nobre. Por fim, a exploração dos mestiços foi uma constante ao longo de toda a colonização, mas, aos poucos, alguns deles foram adquirindo o direito de exercer os mesmos ofícios de brancos não nobres.

Como se vê, cada forma de trabalho estava associada a uma raça específica, e os métodos de controle de determinada forma de trabalho misturavam-se com os métodos de controle da raça correspondente, o que inaugurou uma tecnologia de dominação ${ }^{108}$ baseada na união estratégica entre raça e trabalho que funciona até hoje. Com efeito, é extremamente lucrativo para o capitalismo contemporâneo manter as desigualdades raciais, pois isso facilita sobremaneira a exploração econômica de negros e indígenas que, não

\footnotetext{
${ }^{107}$ Bastante comum em comunidades indígenas, a reciprocidade consiste no "intercâmbio de força de trabalho e de trabalho sem mercado". Ibid. p. 108.

${ }^{108}$ Ibid. p. 109.
} 
por acaso, recebem os menores salários. Estas circunstâncias, quando somadas à desigualdade sexual, evidenciam a posição de extrema vulnerabilidade das mulheres negras e indígenas no atual mercado de trabalho.

Até 1888, porém, o trabalho de negros e negras escravizados não era remunerado, o que, de certa forma, desestimulava a divisão sexual de seu trabalho. A colonialidade do gênero ${ }^{109}$, portanto, foi desde o início articulada com o racismo. Neste sentido, o colonizado, visto como um selvagem, um animal, não era digno de ser chamado de homem ou de mulher, o que não significava, porém, que os ideais europeus de homem e de mulher não serviam como referência para uma avaliação normativa dos comportamentos do colonizado macho e da colonizada fêmea, respectivamente:

Proponho interpretar, através da perspectiva civilizadora, os machos colonizados não humanos como julgados a partir da compreensão normativa do "homem", o ser humano por excelência. Fêmeas eram julgadas do ponto de vista da compreensão normativa como "mulheres", a inversão humana de homens. Desse ponto de vista, pessoas colonizadas tornaram-se machos e fêmeas. Machos tornaram-se nãohumanos-por-não-homens, e fêmeas colonizadas tornaram-se não-humanas-por-nãomulheres. ${ }^{110}$

Como se vê, a categoria sexual teve um papel crucial na desumanização dos povos colonizados. A não humanidade desses machos e dessas fêmeas - e, com este vocabulário, fica clara a perspectiva eurocêntrica de aproximação desses povos com a natureza, com um ambiente primitivo no qual imperam instintos animais - só podia ser certificada por meio de sua não correspondência com o homem branco e com a mulher branca. O não-humano significava, nos termos sexistas dos europeus, o não-homem ou a não-mulher.

\footnotetext{
109 "Uso o termo colonialidade seguindo a analise de Aníbal Quijano do sistema de poder capitalista do mundo em termos da "colonialidade do poder" e da modernidade - dois eixos inseparáveis no funcionamento desse sistema de poder. A análise de Quijano fornece-nos uma compreensão histórica da inseparabilidade da racialização e da exploração capitalista como constitutiva do sistema de poder capitalista que se ancorou na colonização das Américas. Ao pensar a colonialidade do gênero, eu complexifico a compreensão do autor sobre o sistema de poder capitalista global, mas também critico sua própria compreensão do gênero visto só em termos de acesso sexual às mulheres". LUGONES, María. Op. cit., p. 939.

${ }^{110}$ Ibid. p. 937.
} 
Com isso, não se pretende diminuir a importância das colonialidades do saber e do ser, por meio da colonização das memórias, das espiritualidades, dos conhecimentos sobre - e das relações com - o mundo ao redor, das línguas, das noções de si - o que incluiu até mesmo o apagamento dos nomes africanos -, na desumanização e na racialização desses corpos. Pelo contrário, toda a expropriação que forneceu as condições necessárias para que os colonizadores europeus impusessem sua visão de mundo como a única possível era, por si só, uma forma poderosa de desumanização. Mas, antes disso, a própria lógica de expropriação e imposição colonial já pressupunha a inferioridade e desumanidade desses corpos, e essa lógica, na medida em que eurocêntrica, era informada também pelo sexismo. É dizer: a colonialidade do gênero integra as colonialidades do saber e do ser. Podemos constatar, ainda, que a primeira espelha o funcionamento das segundas. De modo paradoxal, o colonizado foi obrigado a, e em certa medida, ansiou por absorver e se comportar de acordo com as visões de mundo do colonizador, o qual, não obstante, recusa e impossibilita essa assimilação ${ }^{111}$. Da mesma forma, ele foi julgado nos termos sexistas europeus de homem e de mulher, ao mesmo tempo em que essa masculinidade e feminilidade, condição indispensável para se adquirir o status de humano, lhe foi negada.

Esta formulação teórica racista - e de forma velada, sexista - era muito conveniente para quem explorava esses corpos. Por não serem mulheres, as escravas podiam e deviam trabalhar tanto quanto os escravos machos. Não havia qualquer diferença entre os sexos que justificasse um trabalho menos produtivo. Por outro lado, quando a distinção entre machos e fêmeas era do interesse dos senhores de engenho, esta era invocada sem maiores reservas. Por exemplo, para diminuir a resistência e a rebeldia das escravas e mantê-las sob

\footnotetext{
111 “A impossibilidade maior, contudo, não está aí. Logo ele [o colonizado] a descobre: ainda que consentisse tudo, não seria salvo. Para ser assimilado, não basta dispensar seu grupo, é preciso penetrar em outro: ora, então ele encontra a recusa do colonizador". MEMMI, Albert. Retrato do colonizado precedido de Retrato do colonizador. Rio de Janeiro: Civilização Brasileira, 2007. p. 166.
} 
controle, ou para puni-las por algum comportamento indesejado, os senhores e feitores recorriam não só a cruéis açoitamentos e espancamentos, como também a estupros sistemáticos, de modo que elas não tivessem dúvidas a respeito de sua inferioridade sexual. Cabe salientar que a exploração econômica e a exploração sexual da mulher negra andam juntas desde o período colonial até os dias de hoje: empregada doméstica e mulata, dois lados de uma mesma moeda, duas representações estereotipadas construídas a partir de uma mesma figura, a mucama. Segundo Lélia Gonzalez:

(...) o engendramento da mulata e da doméstica se fez a partir da figura da mucama. E, pelo visto, não é por acaso que, no Aurélio, a outra função da mucama está entre parênteses. Deve ser ocultada, recalcada, tirada de cena. Mas isso não significa que não esteja aí, com sua malemolência perturbadora. E o momento privilegiado em que sua presença se torna manifesta é justamente o da exaltação mítica da mulata nesse entre parênteses que é o carnaval. Quanto à doméstica, ela nada mais é do que a mucama permitida, a da prestação de bens e serviços, ou seja, o burro de carga que carrega sua família e a dos outros nas costas. Daí, ela ser o lado oposto da exaltação; porque está no cotidiano. E é nesse cotidiano que podemos constatar que somos vistas como domésticas. Melhor exemplo disso são os casos de discriminação de mulheres negras da classe média, cada vez mais crescentes. Não adianta serem "educadas" ou estarem "bem vestidas" (afinal, "boa aparência", como vemos nos anúncios de emprego é uma categoria "branca", unicamente atribuível a "brancas" ou "clarinhas"). Os porteiros dos edifícios obrigam-nos a entrar pela porta de serviço, obedecendo instruções dos síndicos brancos (os mesmos que as "comem com os olhos" no carnaval ou nos oba-oba [...] só pode ser doméstica, logo, entrada de serviço. E, pensando bem, entrada de serviço é algo meio maroto, ambíguo, pois sem querer remete a gente prá outras entradas (não é "seu” síndico?). É por aí que a gente saca que não dá prá fingir que a outra função da mucama tenha sido esquecida. Está aí. ${ }^{112}$

Não é demais ressaltar que, por mais que sejam estereótipos e, portanto,

não reflitam de fato a realidade social das mulheres negras, estas representações discursivas, na medida em que permeiam com toda a força o imaginário social do povo brasileiro, têm o efeito cruel de delimitar os espaços e as posições acessíveis a essas mulheres ${ }^{113}$. Novamente, os discursos produzem a realidade que supostamente descrevem.

\footnotetext{
${ }^{112}$ GONZALEZ, Lélia. Racismo e sexismo na cultura brasileira. In: SILVA, L. A. et al. Movimentos sociais urbanos, minorias e outros estudos. Ciências Sociais Hoje, Brasília, Anpocs, n. 2, p. 230-231, 1984.

113 “A duplicação dos estereótipos como representação e como destino para algumas destas mulheres sugerem um pesado constrangimento para seu enquadramento social. $\mathrm{Na}$ ordem racial-sexual
} 
O abuso e a violência sexual, porém, não se restringiam às escravas fêmeas, ainda que estes as atingissem em proporções muito maiores. A ameaça e a consumação do estupro contra escravos machos funcionavam como uma estratégia de humilhação e de subjugação que não pode ser compreendida fora da lógica dicotômica homem/não-homem, pois é somente em razão de sua não/sub-masculinidade que o escravo macho podia se tornar um objeto sexual. Neste ponto, é possível perceber que esta prática de humilhação que associava os machos não-homens a uma feminilidade e a uma passividade sexual ${ }^{114}$ demonstra de forma muito transparente como os termos eurocêntricos são incapazes de escapar de um raciocínio sexista. Nesse sentido, mesmo quando a lógica eurocêntrica atribui a estes corpos uma hipersexualidade - o que, de certo modo, é contraditório, mas está relacionado, assim como a passividade sexual, à objetificação do corpo negro e a uma definição de sua masculinidade por contraste com a masculinidade hegemônica do homem branco -, ela não foge do dualismo masculino/feminino, pois retira a humanidade do escravo macho por meio da exacerbação de sua masculinidade, que se torna anormal e animalesca em comparação com a do homem branco.

Podemos, ainda, observar os mecanismos traiçoeiros da colonialidade do gênero através de um exame das notórias diferenças entre o controle da sexualidade das mulheres brancas e o das fêmeas não-brancas. As esposas brancas eram induzidas a cultivar a castidade e a abstinência sexual, a fim de que a "pureza" da linhagem hereditária de seus maridos, proprietários de terras e de escravos, fosse garantida. A repressão de sua sexualidade explica, inclusive, os motivos de sua domesticação - pois mantê-las dentro de casa era

naturalizada, o destino das mulheres negras é traçado também pelos estereótipos que acomodam a contradição incorporada em seus corpos e os inscreve no regime local de subordinação". PINHO, Osmundo de Araújo. O efeito do sexo: políticas de raça, gênero e miscigenação. Cadernos Pagu, Campinas, n. 23, p. 115, julho-dezembro de 2004.

114 Esta talvez seja a origem da associação entre homossexualidade e homens negros, cujos corpos estão constantemente sujeitos à objetificação. Dessa forma, é muito importante que o movimento LGBT esteja comprometido com uma análise interseccional da posição vulnerável - mas também subversiva e resistente - ocupada pelo homem negro gay. 
a melhor maneira de vigiá-las. Por outro lado, o controle reprodutivo das negras escravizadas se dava de forma diametralmente oposta. Tendo em vista os interesses econômicos do senhor de multiplicar sua mão-de-obra, os estímulos à reprodução eram muitos, incluindo, por óbvio, o estupro.

A esse respeito, não podemos deixar de enfatizar que esta significativa diferença na construção das imagens da sexualidade da mulher branca e da mulher negra, ou ainda, da mulata, coloca estas últimas, atualmente, numa posição bastante vulnerável no que tange à sua proteção contra assédios, abusos e violências sexuais. Nesse sentido, a conhecida prática na realidade machista brasileira de culpar a vítima pelas violências que sofreu assume proporções gigantescas quando se dirige às mulheres negras, pois o passado violento da escravidão construiu, de forma extremamente eficiente, uma imagem estereotipada que se encaixa perfeitamente naquele raciocínio: por ser vista como moralmente depravada, permissiva e prostituta, torna-se muito mais fácil culpá-la e inocentar o agressor. Além disso, o pensamento machista e heteronormativo de que o homem pode e deve se apropriar do corpo da mulher é intensificado no caso da mulher negra, pois a objetificação de seu corpo é também um efeito do racismo.

Voltando ao período colonial, devemos nos perguntar: o que acontece com as colonialidades do poder, do saber e do ser quando o Brasil se torna um Estado independente em 1822? Num primeiro momento, poderíamos supor que, na ausência dos colonizadores europeus, essas colonialidades se extinguiriam. No entanto, a declaração de independência ocasionou pouquíssimas mudanças no cenário sócio-político brasileiro, e os poucos dominadores brancos que herdaram o papel de seus modelos europeus, e cujos interesses estavam fortemente atrelados à manutenção do sistema de dominação e exploração de pessoas negras e indígenas, continuaram a exercer as colonialidades do poder, do saber e do ser sobre esses grupos, explorando seu trabalho e controlando suas subjetividades e seus saberes. 
O fim da escravização, contudo, gerou certas preocupações para a hegemonia dos brancos. Antes da abolição, a economia de todo o país era sustentada pela exploração do trabalho escravo de negros e negras. Após 1888, quando esse modelo de produção se tornou proibido, a minoria dominante branca se viu numa situação delicada. A conservação de seus privilégios de raça e de classe estava intimamente ligada à perpetuação da exploração econômica daquele grupo. Dessa forma, tornava-se imprescindível garantir que a estrutura de dominação racial permanecesse intacta mesmo após a extinção da escravidão, de modo que negros e negras continuassem a produzir para o desenvolvimento do país e o bem-estar da elite branca. Este problema era resolvido, em parte, pelas barreiras impostas pela própria condição social dos negros, que contavam exclusivamente com sua força de trabalho - na absoluta maioria dos casos, não qualificada - para sobreviver.

Mas a herança sócio-econômica da escravidão não é capaz de explicar sozinha o sucesso obtido pela classe dominante branca. Neste contexto, a colonialidade do ser emerge como um fator chave daquele projeto de exploração. A visão do sujeito negro como naturalmente inferior, pensamento racista presente desde o início do período colonial, se intensifica e é corroborada por estereótipos negativos que associam a população negra com o sujo, o ruim, o feio, o imoral, o incapaz, o irracional e o hipersexual, todos figuras representativas do que Neusa Santos Souza designou como o mito negro $^{115}$. Com isso, para além das trágicas consequências psicológicas que a internalização dessa construção traz ${ }^{116}$, essa subjetificação imposta através da interpelação do negro pelo branco acaba por enrijecer a posição social do sujeito negro. Com efeito, para que ele consiga ascender socialmente, não basta o simples acúmulo de riquezas - como no caso do branco de classe baixa. Ele deve, além disso e sobretudo, recusar sua identidade negra e aderir à

\footnotetext{
${ }^{115}$ SOUZA, Neusa Santos. Tornar-se negro ou as vicissitudes da identidade do negro brasileiro em ascensão social. $2^{\mathrm{a}}$ ed.. Rio de Janeiro: Edições Graal, 1983. p. 27.

${ }^{116}$ Ibid. 88 p.
} 
performance dos estereótipos do comportamento branco. Isso porque esse sujeito inferiorizado e desumanizado, para ser visto como cidadão e tratado como gente, precisa recusar sua negritude e se aproximar do ideal branco. Esse processo de embranquecimento o afasta da comunidade negra. Ele não ajuda a desmistificar a visão pejorativa dos negros em geral, pois se torna a rara exceção em meio à regra: é o(a) negro(a) de alma branca. A ascensão social, portanto, se torna uma luta individual, psicológica e despolitizada contra a visão depreciativa de si mesmo(a), em prejuízo da mobilização coletiva contra o racismo, a violência e a exploração estruturais ${ }^{117}$.

Há de se destacar que a elaboração do mito da democracia racial, amparado nas teorias da miscigenação e baseado na crença em uma suposta harmonia racial, contribuiu sobremaneira para a efetivação deste cenário. Ao formular as noções de que não existe racismo nem desigualdade racial no Brasil, e de que ascenção social é uma questão de esforço, este mito mascara as discriminações e opressões raciais e impede a conscientização, dificultando, com isso, a resistência das raças oprimidas e exploradas. A suposta democracia racial brasileira desempenha o importante papel de ocultar o racismo típico dos países latino-americanos: o racismo disfarçado ou por denegação, como o qualifica Lélia Gonzalez ${ }^{118}$. Diferentemente do racismo aberto, característico dos países de colonização anglo-saxônica, no qual impera a segregação dos grupos não-brancos e a proibição absoluta da miscigenação, o racismo por denegação instaura o mito da democracia racial para negar a si mesmo, ao mesmo tempo em que usa os discursos de miscigenação para, simultaneamente, reforçar aquele mito e recusar qualquer possível conexão com grupos não-brancos, através de um esforço no sentido de um progressivo embranquecimento da população e apagamento das heranças africanas e indígenas. Dessa forma, a ideologia do branqueamento, um dos mecanismos

\footnotetext{
117 Ibid. p. 21.

${ }^{118}$ GONZALEZ, Lélia. A categoria político-cultural de amefricanidade. p. 72.
} 
através dos quais as colonialidades do saber e do ser passaram a operar com o fïm da escravização, é um dos alicerces do racismo disfarçado:

Por isso mesmo, a afirmação de que todos são iguais perante a lei, assume um caráter nitidamente formalista em nossas sociedades. O racismo latinoamericano é suficientemente sofisticado para manter negros e índios na condição de segmentos subordinados no interior das classes mais exploradas, graças à sua forma ideológica mais eficaz: a ideologia do branqueamento. Veiculada pelos meios de comunicação de massa e pelos aparelhos ideológicos tradicionais, ela reproduz e perpetua a crença de que as classificações e os valores do Ocidente branco são os únicos verdadeiros e universais. Uma vez estabelecido, o mito da superioridade branca demonstra sua eficácia pelos efeitos de estilhaçamento, de fragmentação da identidade racial que ele produz: o desejo de embranquecer (de "limpar o sangue", como se diz no Brasil), é internalizado, com a simultânea negação da própria raça, da própria cultura ${ }^{119}$.

A ideologia do branqueamento fundamenta-se na crença da superioridade da raça branca e, portanto, está ligada, ainda que de forma implícita, às teorias raciais do séc. XIX que sustentavam a inferioridade cultural, moral e intelectual de outras raças, especialmente a negra. Como vimos, esta ideologia cumpre o propósito de assegurar a manutenção da exploração econômica das raças tidas como inferiores. Contudo, por ser indissociável do racismo que a informa, esta ideologia vai muito além dos interesses econômicos da elite branca. É neste contexto, portanto, que começa a se desenvolver o que Guerreiro Ramos chamou, em 1957, de patologia social do "branco" brasileiro ${ }^{120}$, que pode ser comparada ao que hoje denominamos ideologia do branqueamento: inseguro quanto à sua branquitude, o branco brasileiro passa a negar suas origens raciais, isto é, recusa qualquer associação genética ou cultural com negros, enquanto busca enfatizar constantemente sua ascendência europeia a fim de reforçar e legitimar sua branquitude.

Por outro lado, essa ideologia exige de negros e negras uma recusa de si mesmos - de sua identidade, de seus corpos e de sua cultura -, bem como um esforço incessante para atingir o ideal branco, não apenas através do branqueamento progressivo da cor da pele e dos traços físicos - empreitada

\footnotetext{
119 Ibid. p. 73.

120 RAMOS, Alberto Guerreiro. Introdução crítica à sociologia brasileira. Rio de Janeiro: Editora UFRJ, 1995. p. 215-240.
} 
que depende fundamentalmente da miscigenação, isto é, da efetivação de relações (hétero) sexuais interraciais, normalmente marcadas por assimetrias de poder, o que sugere que os discursos exaltadores da mestiçagem desempenham um papel oculto de controle sobre a sexualidade de negros e, sobretudo, de negras, associadas, no imaginário racista da população brasileira, estimulado por aqueles mesmos discursos, a uma sensualidade exacerbada e a uma espantosa capacidade de sedução - mas também por meio de mudanças no comportamento, que devem refletir um modo de ser e viver branco, ou supostamente branco, já que não deixa de ser um estereótipo, mesmo que positivo. Essa forma perversa de controle das subjetividades afeta a autoestima de negros e negras ${ }^{121}$, que passam a olhar para si mesmos através dos olhos dos brancos e, a partir daí, começam efetivamente a se enxergar como inferiores, acreditando nos estereótipos negativos construídos pela branquitude brasileira.

Mas o que é, afinal, a branquitude, esta que é responsável tanto pela ideologia do branqueamento como pelo mito da democracia racial? A branquitude é a identidade racial branca, o ponto de vista através do qual os brancos olham para si mesmos e para o mundo, "um lugar de privilégios simbólicos, subjetivos e materiais palpáveis que colaboram para reprodução do preconceito racial, discriminação racial "injusta" e do racismo" 122 . Nesse sentido, é preciso ter em mente que a branquitude se coloca como uma racialidade não nomeada, isto é, como o padrão, o normal, o universal, o que faz com que ela opere de forma velada - em relação aos brancos, pois sua presença nunca foi ignorada por negros -. Esta cegueira por parte dos brancos, de certa forma ligada, no Brasil, ao mito da democracia racial, é extremamente

\footnotetext{
${ }^{121}$ Este impacto sobre a autoestima dos negros está relacionado também com a estrutura de gênero. Homens negros são inferiorizados por não conseguirem alcançar os padrões da masculinidade branca hegemônica que sempre lhe foram negados. As mulheres negras, por sua vez, são diminuídas por não corresponderem aos padrões da feminilidade branca hegemônica. Este fato se torna bastante evidente quando pensamos que as mulheres em geral são socializadas para se preocuparem com a aparência. No entanto, esta imposição é particularmente cruel com as mulheres negras, uma vez que o padrão de beleza é a mulher branca, o que torna esse modelo estético inalcançável.

122 CARDOSO, Lourenço. O branco-objeto: o movimento negro situando a branquitude. Instrumento: R. Est. Pesq. Educ., Juiz de Fora, v. 13, n. 1, p. 81, jan. /jun. 2011.
} 
problemática. Isso porque, ao não enxergarem sua condição racial, os brancos não reconhecem sua posição de privilégio na sociedade e, menos ainda, sua participação na manutenção e ampliação desses privilégios. Daí o mérito do movimento negro por iniciar um processo que situa a branquitude, retirando-a da posição universal e reposicionando-a como um objeto de estudo ${ }^{123}$.

O conceito de branquitude pode ser realmente útil para uma melhor compreensão de diversas questões sociais relevantes, pois permite que o investigador leve em consideração e examine criticamente a perspectiva do branco enquanto grupo hegemônico e dominante. Um bom exemplo deste uso produtivo e, mais do que isso, necessário, é a análise de Maria Aparecida da Silva Bento a respeito do racismo institucional. Nas palavras da autora, "o racismo institucional pode ser entendido como ações em nível organizacional ou da comunidade que independem da intenção de discriminar, mas que têm impacto diferencial e negativo em membros de um grupo" 124 . Como podemos ver, a reprodução do racismo independe de um preconceito explicito e consciente por parte do branco. É dizer: sua intenção não importa, mas sim os efeitos causados por suas ações e discursos. A dificuldade maior, porém, reside no fato de que o racismo será inevitavelmente reproduzido em diversos ambientes e instituições enquanto a população negra for sub-representada, ou seja, enquanto a branquitude - e também podemos dizer, a masculinidade ocupar sozinha todos os espaços de poder e de decisão - no governo, nas empresas, na mídia, etc. -. Isso porque esse grupo dominante, de forma consciente ou não, sempre buscará garantir seus interesses por meio do que Cida Bento chama de "pacto narcísico" 125 , que envolve a constante proteção e afirmação da posição de seu "igual", aquele que é digno de confiança, e a

\footnotetext{
${ }^{123}$ Ibid. p. 81-93.

124 BENTO, Maria Aparecida da Silva. Notas sobre a expressão da branquitude nas instituições. In: BENTO, Maria Aparecida da Silva (Org.). Identidade, branquitude e negritude: contribuições para a psicologia social no Brasil: novos ensaios, relatos de experiência e de pesquisa. São Paulo: Casa do Psicólogo, 2014. p. 26-27.

125 Ibid. p. 17.
} 
exclusão do "outro", o estranho ameaçador. Esta situação é agravada pelo fato do branco muitas vezes não reconhecer seus privilégios nem seus preconceitos. Ele está tão acostumado a ocupar todos os espaços e a se ver representado em todos os ambientes que não questiona os motivos pelos quais está ali sozinho, acreditando, assim, que sua posição é neutra e universal.

Nesta linha, é pertinente, para os propósitos deste trabalho, destacar os elementos comuns da branquitude e da masculinidade, ainda que sejam identidades ou estruturas distintas, com características próprias, pois as duas normalmente articulam-se e ocupam juntas as instâncias de poder. Assim, podemos perceber que a masculinidade, de modo bastante semelhante, inclusive, a o que ocorre com a branquitude, costuma enfatizar a neutralidade e a universalidade de sua posição, ao mesmo tempo em que coloca a feminilidade como o espaço no qual as particularidades do gênero irão verdadeiramente atuar. A branquitude e a masculinidade, ou melhor, as branquitudes e as masculinidades hegemônicas, colocam-se como o padrão normativo de ser humano, o modelo ideal que deve ser alcançado e, com isso, ocultam os privilégios que mantêm esses grupos específicos em posições de poder.

À primeira vista, este cenário pode parecer mais simples do que é. Ocorre que, por serem campos heterogêneos, existem inúmeras branquitudes e masculinidades ${ }^{126}$ que variam não só de acordo com o espaço e com o tempo, mas também segundo hierarquias presentes no interior de uma mesma conjuntura política. Sendo assim, devemos atentar para dois fatores importantes. Primeiro, as branquitudes e masculinidades não são estáticas, mas produzidas e reformuladas em diferentes contextos históricos e sócio-políticos que sofrem influências globais, regionais e locais. Nesse sentido, temos branquitudes e masculinidades globais - ideais de sujeito em um mundo

\footnotetext{
${ }^{126}$ JESUS, Diego Santos Vieira de. Mundo macho: homens, masculinidades e relações internacionais. Revista Brasileira de Estudos Políticos, Belo Horizonte, n. 109, p. 309-364, jul. /dez. 2014.
} 
globalizado -, regionais - europeias, norte-americanas, latino-americanas, africanas, asiáticas, etc. - e locais - germânicas, inglesas, francesas, estadunidenses, brasileiras, argentinas, colombianas, sul-africanas, egípcias, angolanas, nigerianas, chinesas, japonesas, etc., mas também existem subdivisões regionais e locais no interior desses mesmos países -, que se reconstroem e se modificam ao longo do tempo. Elas interagem entre si e, por conta disso, exercem uma forte influência sobre a produção social umas das outras. Por fim, deve-se ressaltar que há uma hierarquia entre elas, uma vez que existem relações de poder entre países e regiões.

Em segundo lugar, as branquitudes e masculinidades de um mesmo local não são uniformes. Existem diversas branquitudes hegemônicas homens-brancos-cis-heterossexuais militares, empresários, proprietários, políticos, etc. - e branquitudes subordinadas - mulheres brancas-cisheterossexuais-de classe alta, homens brancos de classe baixa, homens brancos gays, etc. - que são hegemônicas em relação a outras branquitudes ainda mais subordinadas - mulheres brancas de classe baixa, mulheres brancas lésbicas, mulheres e homens brancos trans, etc., ressaltando que mesmo estas branquitudes não estão em um mesmo nível hierárquico - ou em relação às negritudes ${ }^{127}$. Vale dizer que, as relações entre as negritudes hegemônicas homens negros de classe alta, por exemplo - e as branquitudes subordinadas são complexas, não sendo possível estabelecer a priori uma hierarquia entre elas, fora do contexto no qual essas relações se dão. Da mesma forma, existem diversas masculinidades hegemônicas, assim como inúmeras masculinidades subordinadas - homens negros, homens de classe baixa, homens homossexuais, etc. - que podem ser hegemônicas em relação a outras masculinidades subordinadas e às feminilidades. Enfatizo aqui a palavra "podem", pois nem sempre é isso que vai acontecer.

\footnotetext{
${ }^{127}$ Neste caso, o termo "negritudes" é utilizado de forma a abarcar todas as identidades não-brancas, como por exemplo, as indígenas.
} 
É interessante notar que as branquitudes e as masculinidades são internamente contraditórias. Dessa forma, aquelas que são hegemônicas se definem não só em oposição às negritudes e às feminilidades, mas também em contraposição a outras branquitudes e masculinidades subordinadas. As branquitudes e masculinidades hegemônicas são aquelas posições de poder naturalizadas e reafirmadas - mas também contestadas e questionadas - pela constante reprodução de comportamentos e discursos. São elas que garantem efetivamente a manutenção das estruturas de dominação racial e de gênero, ao determinarem - também pela força, mas principalmente através deste processo de reafirmação por meio de repetições incessantes - quais relações, práticas e discursos são inteligíveis. Por tudo isso, as disputas pela redefinição do campo do inteligível e pela redistribuição do poder se dão tanto entre as branquitudes e negritudes e as masculinidades e feminilidades, como entre as branquitudes hegemônicas e subordinadas e as masculinidades hegemônicas e subordinadas.

Vale dizer que as branquitudes e masculinidades hegemônicas não representam de forma alguma a realidade da maioria dos brancos e dos homens, muito embora todos os brancos e todos os homens se beneficiem, em graus diversos, dos privilégios que decorrem dos sistemas de opressão racial e de gênero. Longe de retratarem as formas de vida de brancos e de homens - até porque as formas de vida são infinitamente variadas e dependem do modo como os sujeitos vão negociar, na prática, as normas de gênero, de raça, etc. ${ }^{128}$ -, as branquitudes e masculinidades hegemônicas são padrões normativos,

\footnotetext{
${ }^{128}$ Há uma importante distinção entre o gênero e a raça enquanto construídos - por meio de discursos que versam sobre as diferenças e categorias de gênero e de raça - e o gênero e a raça enquanto vividos, isto é, as maneiras como os indivíduos irão interpretar - de forma consciente ou não - esses discursos e utilizá-los para fazerem representações de si e dos outros e para forjarem-se como sujeitos marcados pelo gênero e pela raça e cujas práticas reproduzirão aqueles discursos. L. MOORE, Henrietta. Fantasias de poder e fantasias de identidade: gênero, raça e violência. Cadernos Pagu, Campinas, n. 14, p. 15-18, jun. 2015. Embora haja uma evidente correlação entre ambos, não é possível fundi-los numa só e mesma coisa: "O fato intrigante sobre essas representações ou categorizações dominantes é que elas têm apenas relações tangenciais com os comportamentos, qualidades, atributos e autoimagens das mulheres e homens individuais. Discursos sobre gênero e categorias de gênero não são poderosos porque oferecem descrições acuradas de práticas e experiências sociais, mas porque, entre outras coisas, produzem homens e mulheres marcados por gênero, como pessoas que são definidas pela diferença". Ibid. p. 17.
} 
modelos ideais instituídos historicamente com o propósito de impor comportamentos e orientar o funcionamento das estruturas de dominação.

Por todo o exposto, pensar em gênero e em raça só faz sentido em termos relacionais. A posição social de um sujeito não é fixa, mas relativa, na medida em que só adquire significado em relação à posição social do sujeito com quem ele se relaciona e vice-versa. A posição de uma mulher branca de classe média, por exemplo, certamente se modifica caso ela esteja se relacionando com um homem branco ou com um homem negro, com um homem de classe média ou de classe baixa, ou ainda com uma mulher negra. Além disso, e como consequência deste raciocínio, podemos concluir que é impossível compreender as relações de gênero sem pensar em raça, classe, orientação sexual, religião, etc. Toda opressão de gênero está conectada a outros fatores determinantes que, por sua relevância na compreensão daquele contexto específico, não podem ser desconsiderados. Isso vale não só para mulheres sujeitas a mais de uma forma de opressão, mas para todas as mulheres, pois, caso contrário, correremos o risco de universalizar experiências bastante particulares.

Dito isso, torna-se bem mais fácil enxergar as particularidades do contexto opressivo da mulher branca de classe média ou alta, particularidades que não podem ser universalizadas e tomadas como o interesse geral das mulheres. A luta pela inserção no mercado de trabalho como estratégia de combate ao papel confinante de esposa - aquela que cuida do lar e dos filhos -, embora tenha seu valor e não deva ser desprezada, nunca refletiu as necessidades das mulheres negras, que trabalham e são exploradas desde a época da escravidão, ou mesmo das mulheres brancas de classe baixa, que há muito tempo precisam trabalhar para sobreviver e garantir o sustento de suas famílias.

Assim, repensar o conceito de interseccionalidade é uma tarefa que se impõe. Formulado por feministas negras estadunidenses num contexto em que 
sua posição como mulheres negras era invisibilizada pelas posições hegemônicas da feminilidade branca e da negritude masculina, o termo foi fundamental no que se refere ao deslocamento dos debates a respeito das lutas dos grupos marginalizados, que passaram a ser pautados por novos parâmetros, os quais enfatizavam a dinâmica interação entre distintos sistemas de opressão. Entretanto, este importante e necessário passo, responsável por uma percepção renovada das relações de poder, é insuficiente, pois incapaz de explicar plenamente a profunda imbricação entre as estruturas de dominação, cuja articulação não está presente apenas em contextos específicos nos quais duas ou mais estruturas se sobrepõem - como no caso de mulheres negras pobres.

O termo interseccionalidade, embora não deva ser descartado em razão de seu peso histórico, bem como de seu notável papel epistêmico, precisa ser analisado criticamente e reconhecido em suas limitações. Nesse sentido, cabe lembrar que o termo evoca a imagem matemática da interseção entre círculos, os quais cada um representaria um sistema de dominação. Esta imagem, por mais didática que seja, confunde o(a) leitor(a) e desvia completamente seu raciocínio, conduzindo-o(a) a uma visão destituída de toda a complexidade inerente às relações de opressão, que não podem ser entendidas separadamente. Como vimos, a linha divisória entre a zona do ser e a zona do não ser é determinante para qualquer análise de gênero, seja para avaliarmos a situação das mulheres negras, das mulheres brancas, dos homens negros ou dos homens brancos, seja para analisarmos de que maneiras essas categorias se relacionam entre si. Por isso, a interseccionalidade deve sempre ser interpretada à luz da decolonialidade, que evidenciou as imbricadas relações entre as diversas estruturas de opressão contidas no sistema mundial moderno/colonial de poder capitalista, patriarcal, racista e heteronormativo:

Compreender a imbricação das opressões não se trata de colocar categorias que conformam uma somatória de experiências, ou uma interseção de categorias analíticas (CRENSHAW, 1993), se trata de entender como estas têm atravessado historicamente nossa região desde o colonialismo até a colonialidade contemporânea e como elas têm se expressado em certos sujeitos que não têm tido privilégios de 
raça, classe, sexo e sexualidade, como no caso das mulheres negras, indígenas e camponesas da região ${ }^{129}$.

Deste modo, gênero, raça, classe, sexualidade, etc., devem ser compreendidos não como simples identidades, mas como estruturas de relações de poder que imprimem suas marcas nas subjetividades dos indivíduos. Por isso, Ochy Curiel nos alerta ${ }^{130}$ para os perigos de uma aposta nas políticas de identidade como um fim em si mesmo, e não apenas como um meio para a emancipação. Segundo a autora ${ }^{131}$, essas políticas foram fundamentais no início da articulação do movimento feminista negro, pois permitiram uma reafirmação e uma descolonização de suas subjetividades enquanto mulheres e negras ${ }^{132}$, além de garantirem uma maior visibilidade de suas demandas sociais. Por outro lado, o esforço contínuo para promover a unidade do grupo e assegurar uma suposta igualdade entre as mulheres negras levou, como aconteceu com o feminismo branco, a um não reconhecimento das diferenças no interior do grupo, o que prejudicou a formulação de políticas concretas e efetivas, capazes de considerar todas as complexas posições ocupadas por mulheres negras. Portanto, é pertinente salientar, uma vez mais, que a heterogeneidade interna de qualquer grupo social jamais pode ser ignorada, pois, caso contrário, corre-se o risco de serem efetuadas exclusões. As múltiplas dimensões de cada subjetividade devem ser constantemente explicitadas. Ademais, há de se acrescentar que a importância do grupo - como representante daquelas mulheres e intermediador na luta por direitos - não

\footnotetext{
129 Tradução nossa: "Comprender la imbricación de las opresiones no se trata de colocar categorías que conforman una sumatoria de experiencias, o una intersección de categorías analíticas (CRENSHAW, 1993), se trata de entender cómo estas han atravesado históricamente nuestra región desde el colonialismo hasta al colonialidad contemporánea y como se ha expresado en ciertos sujetos que no han tenido privilegios de raza, clase, sexo y sexualidad, como son las mujeres negras, indígenas y campesinas de la región". CURIEL, Ochy. De las identidades a la imbricación de las opresiones: desde la experiencia. In: FLAUZINA, Ana; PIRES, Thula (org.). Encrespando - Anais do I Seminário Internacional: Refletindo a Década Internacional dos Afrodescendentes (ONU, 2015-2024). Brasília: Brado Negro, 2016. p. 80.

${ }^{130}$ Ibid. p. 84.

${ }^{131}$ Ibid. p. $75-78$.

${ }^{132}$ Neste contexto, foi possível, por exemplo, reapropriar-se das espiritualidades e religiosidades de origem africana e formular uma estética que valorize a beleza negra. Ibid. p. 76.
} 
pode justificar o enrijecimento da identidade grupal, que está sujeita a incessantes reformulações e deslocamentos - o que tanto favorece a inclusão de mulheres antes excluídas como impede o aprisionamento das que já eram integrantes. Afinal, a construção da subjetividade é um processo inacabado, postergado de forma permanente.

No próximo capítulo, utilizaremos a Lei Maria da Penha - Lei $\mathrm{n}^{\circ}$ 11.340/2006 - e o crime de feminicídio - art. 121, § 2º VI, do Código Penal como exemplos de respostas jurídicas, em parte, frustradas, que buscam combater violências relacionadas à desigualdade de gênero. A partir de uma perspectiva interseccional e decolonial, analisaremos o nível de eficácia - ou ineficácia - dessas medidas legais e, com isso, evidenciaremos o olhar míope do Direito no que se refere à complexa articulação entre as diversas estruturas de opressão existentes em nossa sociedade. 


\section{A violência doméstica e familiar contra a mulher e a ausência de um olhar interseccional na busca de soluções jurídicas}

Nos capítulos anteriores, vimos que os sujeitos são formados e categorizados de forma hierárquica através de mecanismos discursivos. Com efeito, cada cultura conta, em seu interior, com uma multiplicidade de discursos sobre gênero, raça, classe, orientação sexual, etc., lembrando que a imbricação entre essas categorias está refletida na formulação de cada um desses discursos. Assim, vale ressaltar que não existe apenas um discurso a respeito da feminilidade, mas sim incontáveis discursos que, longe de serem coerentes e harmônicos, são muitas vezes contraditórios e conflitantes ${ }^{133}$. O mesmo ocorre com as diversas branquitudes, negritudes e masculinidades. Diante disso, esses numerosos discursos entram em disputa para forjar e constituir indivíduos que, por sua vez, assumem não uma, mas múltiplas e contraditórias posições de sujeito - marcadas pelo gênero, pela raça, etc. - que integram, simultaneamente, sua subjetividade ${ }^{134}$. A partir desses múltiplos discursos e representações sociais, os indivíduos construirão diversas imagens representativas de posições de sujeito marcadas por aquelas categorias e investirão nas posições que desejam ocupar, tendo em vista as vantagens que elas prometem oferecer ${ }^{135}$.

Neste ponto, convém salientar que os benefícios oferecidos pelas posições de sujeito são nada menos do que os efeitos materiais e de poder advindos dos discursos e práticas institucionais que produzem as categorias

\footnotetext{
${ }^{133}$ Podemos citar, como exemplo, a relação entre os discursos que exaltam a maternidade, os discursos que ressaltam a fragilidade e a delicadeza da mulher e os discursos que defendem a força da mulher independente e autônoma. Todos eles podem ou não ser considerados incompatíveis entre si, mas, de qualquer forma, é preciso reconhecer que essas posições coexistem na vida de muitas mulheres.

${ }^{134}$ L. MOORE, Henrietta. Op. cit., p. 22-27.

${ }^{135}$ Ibid. p. 36.
} 
hierarquizadas e, posteriormente, sancionam as subjetividades que se conformam a elas:

É importante reconhecer que o investimento [em determinadas posições de sujeito] é uma questão não apenas de satisfação emocional, mas de benefícios materiais sociais e econômicos muito reais que são a retribuição do homem respeitável, da boa esposa, da mãe poderosa ou da filha bem comportada em muitas situações sociais. É por essa razão que modos de subjetividade e questões de identidade estão ligadas a questões de poder, e aos benefícios materiais que podem ser uma conseqüência do exercício desse poder ${ }^{136}$.

Vê-se, deste modo, que as fantasias de poder dos sujeitos estão intimamente ligadas às fantasias de identidade ${ }^{137}$. Ocupar certas posições significa adquirir certos poderes e prestígio em relação a outros sujeitos e outras posições, menos valorizados nos discursos dominantes. Este cenário se complexifica ao considerarmos que o poder, a força e a violência são frequentemente sexualizados e racializados ${ }^{138}$. Isso não significa, por exemplo, que mulheres não têm poder, mas que, em certos contextos - não todos, pois algumas feminilidades são de fato associadas a certas espécies de poder e de força -, o poder manejado por elas será consequência da corporificação de uma posição de sujeito marcada pelo gênero masculino.

Ocorre que, quando os indivíduos não conseguem atingir estas posições de sujeito de forma plena ou satisfatória - o que envolve possíveis conflitos entre posições de sujeito contraditórias assumidas por um mesmo indivíduo -, ou ainda, quando não recebem o reconhecimento ou os benefícios que esperavam obter ao assumi-las inicialmente, suas representações de si são abaladas, o que gera conflitos que podem deflagrar violências ${ }^{139}$. Por outro lado, as expectativas em relação às posições de sujeito dos outros, quando frustradas, podem ter os mesmos efeitos. A violência pode ser uma forma ou tentativa de garantir a eficácia daquelas posições, ou uma maneira de prevenir o insucesso das mesmas. Desta maneira, a violência funciona como um

\footnotetext{
${ }^{136}$ Ibid. p. 37.

${ }^{137}$ Ibid. p. 38.

${ }^{138}$ Ibid. p. 34-35.

${ }^{139}$ Ibid. p. 39.
} 
poderoso mecanismo de reprodução dos discursos a respeito do gênero, da raça, da sexualidade, etc., e muitas vezes é invocada tanto para afirmar o êxito da interiorização de certo discurso, efetivamente transformado em posição de sujeito de um indivíduo, quanto para "dirimir" conflitos gerados pela não correspondência entre as auto-representações dos individuos - inspiradas nos discursos dominantes - e as posições de sujeito que eles de fato ocupam.

Feitas essas considerações, podemos descrever a violência de gênero como a violência provocada por conflitos que, por sua vez, surgem em razão da frustração de expectativas vinculadas aos papeis e posições que supostamente devem ser assumidos por sujeitos femininos e masculinos. A violência de gênero, portanto, não se resume à violência de homens contra mulheres, já que pode ser perpetrada pela mãe ou pelo pai contra seus filhos e filhas e está presente, inclusive, em relacionamentos homossexuais. Ademais, sua dinâmica é complexa e não pode ser compreendida por meio de um simples olhar dirigido exclusivamente às atitudes e aos motivos do agressor - $\mathrm{o}$ que não altera o fato de que ele é o único responsável pela violência -, pois é necessário ter uma visão abrangente da relação conflituosa, o que inclui as posições de sujeito e as expectativas da vítima.

Ainda que a violência de gênero não se restrinja à violência contra a mulher, é necessário reconhecer que a interseção entre elas é consideravelmente grande. Isso porque as representações discursivas da violência são sexualizadas e, por isso, muitos homens buscam afirmar suas masculinidades por meio da agressividade, atributo tipicamente representado como masculino. De acordo com esta lógica, a violência confirma a identidade masculina, posição - ou performance de gênero - que é retribuída com o poder masculino, o qual, por sua vez, legitima o uso da violência.

De forma previsível, o ambiente mais propício para a proliferação da violência de gênero ou, mais especificamente, da violência contra a mulher, é o espaço doméstico e familiar. De fato, a família mononuclear da sociedade 
ocidental é uma poderosa instituição em torno da qual circulam numerosos discursos que reforçam papeis e posições marcados pelo gênero. No âmbito da família tradicional do ocidente - ou até mesmo em relações íntimas de afeto não matrimoniais -, o marido/pai/companheiro/namorado/ficante possui o poder disciplinador ${ }^{140}$, isto é, ele tem o poder de corrigir as atitudes "inapropriadas" de sua esposa/companheira/namorada/ficante e de seus filhos e filhas, podendo, inclusive, usar a violência como forma legítima de garantir a eficácia de sua correção. Assim, caso este homem se veja ameaçado ou questionado em suas posições de sujeito - provedor, chefe de família, homem ativo da relação -, ou caso a esposa, as filhas ou os filhos não supram suas expectativas quanto às posições de sujeito que devem assumir, a violência se coloca como um possível instrumento retificador.

As observações que fizemos até agora dão conta apenas da dimensão de gênero relacionada à violência doméstica e familiar contra a mulher. É necessário, portanto, aprofundar nossa análise e levar em conta outros fatores determinantes.

\subsection{Contextualizando a violência doméstica e familiar contra as mulheres negras}

Como vimos nos capítulos anteriores, os diversos eixos de organização do poder articulam-se para determinar as múltiplas e heterogêneas formas de vida em nossa sociedade hierarquizada, impactando, de modo desigual, a vida de mulheres diferentemente localizadas. Evidentemente, isto se aplica também aos contextos de violência e, no que se refere às mulheres negras, o entrecruzamento entre gênero e raça as coloca em uma posição cujo status

\footnotetext{
${ }^{140}$ Vale lembrar que nem sempre o poder disciplinador será incorporado por um homem, já que também as mulheres podem assumir posições consideradas masculinas. Dessa forma, uma mãe pode exercer este poder em relação aos seus filhos e filhas, por exemplo. PEREIRA, Bruna Cristina Jaquetto. Tramas e dramas de gênero e de cor: a violência doméstica e familiar contra mulheres negras. Brasília: Brado Negro, 2016. p. 66.
} 
social inferior modifica a experiência da violência doméstica e familiar. Além disso, por serem indissociáveis, as dimensões de gênero e de raça - e os discursos que as constituem - irão atuar de forma conjunta e entrelaçada nas dinâmicas de violência do ambiente doméstico, influenciando tanto os momentos nos quais a violência será evocada quanto os modos através dos quais ela será exprimida.

Entretanto, a análise da estrutura de dominação racial e de suas implicações para o contexto da violência doméstica e familiar contra a mulher é praticamente inexistente no Brasil, não obstante as inúmeras pesquisas voltadas para o estudo desta forma de violência. Neste ponto, devemos retornar aos conceitos de subinclusão e sobreinclusão cunhados por Kimberlé Crenshaw, na medida em que são úteis para compreendermos a invisibilidade das experiências de violência vividas por mulheres negras. Com efeito, podemos dizer que, quando a imbricada relação entre gênero e raça gera dinâmicas de violência que são interpretadas como consequência exclusiva do gênero feminino da vítima - por exemplo, quando uma mulher negra é controlada rigidamente em sua sexualidade, em razão do imaginário racista e sexista que a hipersexualiza -, temos então uma superinclusão, isto é, uma absorção indevida pela ordem do gênero, que oculta outras estruturas determinantes naquele contexto interseccional. Por outro lado, quando as agressões sofridas por mulheres negras não espelham a realidade das mulheres brancas - insultos racistas, com o intuito de humilhar e diminuir a autoestima da vítima -, essas violências não são reconhecidas ou nomeadas como violência doméstica ou, muitas vezes, não são nem mesmo identificadas ${ }^{141}$, o que evidencia a ocorrência do fenômeno da subinclusão, ou seja, esta violência

\footnotetext{
141 As entrevistas de Bruna Pereira com mulheres negras vítimas de violência doméstica apontaram para uma dificuldade real das entrevistadas em admitir que eram vítimas de racismo ou de insultos racistas por pessoas próximas. Além disso, este assunto nunca surgia de forma espontânea durante os relatos de violência doméstica, e era preciso que a entrevistadora fizesse perguntas diretas e reiteradas sobre o tema para que obtivesse respostas que, ainda assim, se mostravam tímidas. Por fim, mesmo quando as ofensas e discriminações raciais eram reconhecidas, estas não eram vistas como parte integrante do contexto mais amplo de violência doméstica. Ibid. p. 173, 177-179.
} 
não é reconhecida como um problema causado nem pela desigualdade de gênero nem pela desigualdade racial, apesar de ser fruto de ambas.

Como remediar esta situação? De que formas podemos abordar a violência de gênero, de modo que todos os elementos importantes sejam considerados? Uma possível resposta está no projeto decolonial, cuja perspectiva pode nos ser imensamente útil, na medida em que põe em relevo a necessidade do sistema mundial de poder capitalista, iniciado com o período colonial, mas constantemente reatualizado e perpetuado até os dias de hoje, em manter as subordinações por gênero e por raça como forma de garantir o funcionamento desta matriz de poder. Nesta linha, as colonialidades do poder, do ser e do saber continuam operando e têm no âmbito privado da vida doméstica um forte aliado na reprodução e manutenção das hierarquias sociais. A violência, instrumento de autoafirmação e de subjugação profundamente conectado ao racismo e ao sexismo, é uma herança histórica do colonialismo que permanece sendo naturalizada no contexto familiar ${ }^{142}$. A esse respeito, frise-se novamente que o sentido atribuído ao termo família tem sua origem no ocidente $^{143}$, já que esta importante instituição é um dos pilares da matriz colonial de poder.

Observe-se que o acesso pleno e privilegiado de homens brancos ao mercado de trabalho e, portanto, ao mundo público e à cidadania, só são possíveis em razão das opressões por gênero e por raça, que remontam ao período colonial. Assim, a colonialidade do poder exige que mulheres negras e

\footnotetext{
142 ALMEIDA, Tânia Mara Campos de; PEREIRA, Bruna Cristina Jaquetto. Violência doméstica e familiar contra mulheres pretas e pardas no Brasil: reflexões pela ótica dos estudos feministas latinoamericanos. Crítica e Sociedade: revista de cultura política. v. 2, n. 2, Dossiê: Cultura e Política, p. 60, dez. 2012.

143 OYĚWÙMÍ, Oyèrónké. Conceituando o gênero: os fundamentos eurocêntricos dos conceitos feministas e o desafio das epistemologias africanas. Tradução para uso didático de: OYĚWÙMí, Oyèrónké. Conceptualizing Gender: The Eurocentric Foundations of Feminist Concepts and the challenge of African Epistemologies. African Gender Scholarship: Concepts, Methodologies and Paradigms. CODESRIA Gender Series. Volume 1, Dakar, CODESRIA, 2004, p. 1-8, por Juliana Araújo Lopes. No mesmo sentido: OYÈWÚMI, Oyèronké. Family bonds/Conceptual Binds: African notes on Feminist Epistemologies. Signs, Vol. 25, No. 4, Feminisms at a Millennium (Summer, 2000), p. 1093-1098. Tradução para uso didático por Aline Matos da Rocha.
} 
brancas assumam as tarefas domésticas e os cuidados com os filhos, mas as primeiras devem, além disso, sustentar suas famílias - uma realidade em suas vidas desde a abolição da escravidão -, o que reforça seu aprisionamento, pois são obrigadas a aceitar trabalhos e ocupações mal remunerados e pouco valorizados em nossa sociedade. Esta situação é agravada pela luta das mulheres brancas por reconhecimento e espaço no mercado de trabalho, uma vez que são as mulheres negras que, enquanto empregadas domésticas, irão substituí-las em suas tarefas, sem, contudo, usufruírem dos benefícios econômicos de seu trabalho, que é explorado. Portanto, podemos dizer que o confinamento das mulheres negras na esfera privada se perpetua mesmo nos casos em que elas trabalham fora de casa, impondo-lhes o risco de serem agredidas e violentadas no âmbito doméstico do empregador ${ }^{144}$. O cenário acima descrito deve ser interpretado à luz dos interesses da colonialidade do poder:

O mundo privado figura como locus basilar onde as relações sociais com as mulheres pretas e pardas seguem acorrentadas, não lhes sendo permitido deles saírem sob risco de ruir todo o padrão de colonialidade do poder. A engenhosa arquitetura do poder colonial, desdobrada no imperialismo atual, tem como pilar a violência constitutiva e naturalizada das relações domésticas e familiares, em especial aquelas estabelecidas com as mulheres cuja alteridade é ainda mais marcada e objetificada: as pretas, as pardas, as indígenas, dentre outras minorias do grupo genérico das mulheres. (...). Por isso, é tão importante para as mulheres pretas e pardas que o âmbito privado seja politizado e definido como núcleo central de conflitos de poder na sociedade - ele não pode, de modo algum, ser considerado um âmbito "pré-político"145.

Assim como as mulheres brancas, os homens negros viram na exploração e inferiorização da mulher negra uma oportunidade para elevarem seu status social. Já durante o período colonial, o patriarcado e a opressão de gênero eram as bases de certa solidariedade entre homens brancos e negros. No entanto, a condição racial dos homens negros vem impedindo que desfrutem de todos os privilégios assegurados à masculinidade. Em razão disso, muitos transformaram a luta contra o racismo na luta para assumir sua "posição de

\footnotetext{
144 ALMEIDA, Tânia Mara Campos de; PEREIRA, Bruna Cristina Jaquetto. Op. cit., p. 57-58.

145 Ibid. p. 59-60.
} 
direito" na sociedade patriarcal, em igualdade com homens brancos, como bem demonstraram as feministas negras norte-americanas ${ }^{146}$. Para tanto, deveriam subjugar e impor limites às suas parceiras, cuja "autonomia excessiva", supunham eles, era responsável por sua emasculação.

$\mathrm{Na}$ verdade, por terem sua humanidade negada durante a escravidão, os machos e fêmeas escravizados não puderam compartilhar dos atributos e representações típicas da masculinidade e feminilidade hegemônicas, isto é, brancas. Tal fato, que ainda se reflete na atualidade, acarreta graves consequências para as relações interpessoais cotidianas no contexto domiciliar. Em suas entrevistas com mulheres negras - pretas e pardas - vítimas de violência doméstica, Bruna Pereira identificou situações em que o marido, também negro e muitas vezes mais escuro do que a esposa, busca mitigar sua suposta inferioridade racial por meio da afirmação de sua masculinidade, seja através da ênfase de seu papel como provedor ${ }^{147}$ - o que envolve comentários constantes e humilhantes a respeito da dependência econômica da companheira -, seja mediante o acesso sexual a mulheres brancas. Neste último caso, o marido reforça sua superioridade em relação à esposa não apenas por diminuila perante as mulheres brancas, mas por ser capaz de igualar-se aos homens brancos - na medida em que compartilha com eles o mesmo objeto sexual -, o que legitima sua posição masculina e os privilégios dela decorrentes ${ }^{148}$. Seguindo este raciocínio, podemos compreender com maior facilidade a solidão da mulher negra, frequentemente rejeitada por homens negros que pretendem ascender socialmente e aproximar-se do status do homem branco por meio de casamentos com mulheres brancas ${ }^{149}$.

\footnotetext{
${ }^{146}$ Ibid. p. 54. bell hooks. Op. cit., p. 87-117.

${ }^{147}$ PEREIRA, Bruna Cristina Jaquetto. Tramas e dramas de gênero e de cor: a violência doméstica e familiar contra mulheres negras. p. 162-164.

148 Ibid. p. 127-131.

149 "Os dados sobre seletividade marital confirmam estatisticamente essa mesma preferência dos homens pretos/pardos pelas mulheres brancas e apontam para a existência de dinâmicas semelhantes no contexto brasileiro atual. Conquanto se verifique na distribuição censitária por cor um excedente de homens pretos e pardos em relação a mulheres pretas e pardas, e um excedente de mulheres brancas
} 
É importante destacar, ainda, que a feminilidade branca hegemônica coloca-se como o referencial de feminilidade para as mulheres em geral, o que gera frustrações tanto em mulheres não brancas, por não serem capazes de atingir aquele padrão normativo - já que este lhe é negado de forma automática -, quanto em seus parceiros - brancos ou negros -, cujas expectativas em relação às condutas e posições de sujeito daquelas mulheres não são atendidas, intensificando-se, assim, possíveis conflitos desencadeadores de violência.

Ademais, as próprias representações da feminilidade negra presentes no imaginário da população brasileira interferem significativamente nas posturas e práticas cotidianas que se dão no interior do ambiente doméstico e familiar. Antes de adentrar neste assunto, porém, faz-se necessária a desmistificação dos discursos a respeito da miscigenação. Nesse sentido, são muitos aqueles que acreditam que a miscigenação é uma prova de que o racismo não existe ou, ao menos, vem sendo atenuado em decorrência do maior número de relacionamentos e casamentos inter-raciais. É preciso recordar, todavia, que a miscigenação funcionou como projeto de genocídio do povo negro, posto que buscava nada menos do que o embranquecimento progressivo da população brasileira. Com isso em vista, podemos dizer que a ausência de segregação racial explícita no Brasil de forma alguma torna o racismo mais brando em comparação com o de outros países. Os maiores índices de casamento interracial significam simplesmente que as relações raciais operam a partir de uma lógica diferente:

Afinal, como busco demonstrar em outros momentos, a convivência inter-racial não prescinde, necessariamente, da suposição de hierarquias com base na raça/cor, da mediação de representações sociais racistas ou de práticas discriminatórias. Ao contrário, a própria possibilidade de interação social inter-racial pode apoiar-se na sua existência ${ }^{150}$.

em relação a homens brancos, as mulheres pretas são as que se casam menos e mais tarde (Berquó, 1988; Moutinho, 2004). Nos casamentos inter-raciais, prevalecem as uniões em que a mulher é o elemento mais claro". ALMEIDA, Tânia Mara Campos de; PEREIRA, Bruna Cristina Jaquetto. Op. cit., p. 54.

${ }^{150}$ PEREIRA, Bruna Cristina Jaquetto. Tramas e dramas de gênero e de cor: a violência doméstica e familiar contra mulheres negras. p. 38. 
Desta forma, os relacionamentos inter-raciais, longe de evidenciarem uma suposta harmonia racial, retratam espaços de proliferação de hierarquias raciais e de comportamentos racistas - o que não significa que relacionamentos intraraciais estejam imunes a essas dinâmicas racistas, como já vimos -. Um bom exemplo disso é o desapontamento dos pais quando os filhos e filhas são mais escuros do que o esperado. Neste caso, a percepção de que houve uma aproximação indesejada - por meio do laço consanguíneo - com a raça tida como inferior estimula estes homens a assumirem posições defensivas em relação à sua identidade racial, o que envolve, muitas vezes, o uso da violência como forma de marcar um distanciamento em relação aos filhos e filhas, bem como em relação à esposa/mãe, considerada culpada pela presença da "mancha afrodescendente" na família ${ }^{151}$.

Considerando tal horizonte das relações raciais no Brasil, vejamos agora as representações discursivas e imagens da feminilidade negra e os sentidos que estas adquirem no contexto familiar e nas dinâmicas de violência doméstica. Para tanto, devemos retornar ao período da escravidão, uma vez que este foi determinante na construção daquelas imagens. Com efeito, as mulheres negras escravizadas eram obrigadas a trabalhar exaustivamente, nas mesmas condições impostas aos homens negros. Além disso, estavam sujeitas a constantes espancamentos, bem como a estupros sistemáticos, já que eram vistas como meros objetos a serviço dos interesses econômicos e sexuais de seus proprietários. Há de se acrescentar, ainda, que sua inferiorização e desumanização as destituíam dos traços mais valorizados da feminilidade branca: a beleza e a virtude - pureza e castidade - femininas. Por tudo isso, integram o imaginário da população brasileira as seguintes representações da mulher negra: trabalhadora incansável, dotada de extraordinária força física, sexualmente disponível, puta, sedutora, feia ${ }^{152}$.

\footnotetext{
${ }^{151}$ Ibid. p. 122-124.

152 ALMEIDA, Tânia Mara Campos de; PEREIRA, Bruna Cristina Jaquetto. Op. cit., p. 56.
} 
Todas essas imagens representativas da feminilidade negra apareceram nas entrevistas de Bruna Pereira com mulheres pretas e pardas vítimas de violência doméstica, determinando os espaços e posições de sujeito que elas poderiam ocupar e conferindo significados às suas vivências. Podemos perceber, ainda, que as expectativas e atitudes dos parceiros em relação a elas foram influenciadas por essas imagens. Por serem vistas como trabalhadoras, as mulheres negras - sobretudo as pretas - são muitas vezes exploradas economicamente por seus companheiros, que exigem não só que elas trabalhem, mas que sejam provedoras exclusivas do lar. Destaque-se que, em alguns casos, a superioridade racial e de gênero do companheiro branco é interpretada por ele como uma dívida contraída pela parceira - pelo simples fato de ele estar com ela -, que deve, como contrapartida, garantir o seu sustento. Neste cenário, qualquer contestação da parte dela pode acionar práticas e posturas violentas - de ofensas racistas a agressões físicas ${ }^{153}$. Para além disso, a ideia de que as mulheres negras são fortes e resistentes pode motivar condutas absurdamente violentas, afinal, "elas aguentam"154.

No que se refere à hipersexualização da mulher negra - tanto pretas quanto pardas, mas com maior ênfase às segundas, por sua aproximação com a figura da mulata -, podemos citar como principal consequência o controle severo de sua sexualidade e de suas relações pessoais. No entanto, com relação às mulheres pretas, este controle pode ser visto como dispensável pelos parceiros, já que, por não se encaixarem no padrão de beleza feminino, que é branco, muitas delas são consideradas pouco atraentes. Esta atitude despreocupada se transforma quando eles percebem que há alguma chance de envolvimento com outro homem. Nesta hipótese, o grupo de mulheres negras como um todo é atacado e condenado, e as parceiras são acusadas de agirem

\footnotetext{
${ }^{153}$ PEREIRA, Bruna Cristina Jaquetto. Tramas e dramas de gênero e de cor: a violência doméstica e familiar contra mulheres negras. p. 150-158.

154 ALMEIDA, Tânia Mara Campos de; PEREIRA, Bruna Cristina Jaquetto. Op. cit., p. 59.
} 
ativa e maliciosamente na sedução de seus pretendentes ${ }^{155}$. Por fim, frise-se que o status social inferior que lhes é atribuído - por serem mulheres e negras -, bem como a constante desvalorização de sua humanidade, as colocam em posição de vulnerabilidade no que tange a violências sexuais, ofensas verbais e humilhações - explicitamente racistas ou não ${ }^{156}$.

Essas dinâmicas estão presentes na vida de muitas mulheres negras, independentemente da classe social. Contudo, não podemos ignorar o fato de que a pobreza limita as possibilidades de enfrentamento da situação de violência ${ }^{157}$. Nos casos em que há uma dependência econômica da vítima em relação ao agressor - o que é mais provável se ela for pobre e não puder contar com a ajuda de parentes, na maioria das vezes, igualmente pobres -, abandonar o ofensor pode ser uma opção inviável. Ademais, a pobreza dificulta o acesso a recursos e meios de proteção a direitos. As vias institucionais normalmente utilizadas para a efetivação de direitos muitas vezes não estão acessíveis para as camadas mais pobres da população e, mesmo quando isso não é verdade e o acesso é garantido, a estrutura e os mecanismos de apoio disponíveis são insuficientes e inadequados para o atendimento das necessidades específicas das mulheres que se encontram nas classes mais baixas, uma vez que elas precisam de toda uma gama articulada de serviços e infraestruturas: abrigos e programas de habitação, programas de qualificação e de inserção no mercado de trabalho, creches, serviços de saúde, etc ${ }^{158}$. Vale dizer que, se os direitos básicos garantidos pela Constituição Federal não lhes fossem negados em um primeiro momento, não haveria necessidade de mobilizar tantos recursos e serviços no âmbito da prevenção e coibição da violência doméstica contra essas mulheres.

\footnotetext{
155 PEREIRA, Bruna Cristina Jaquetto. Tramas e dramas de gênero e de cor: a violência doméstica e familiar contra mulheres negras. p. 136-149, 175.

${ }^{156}$ ALMEIDA, Tânia Mara Campos de; PEREIRA, Bruna Cristina Jaquetto. Op. cit., p. 58-59.

157 Ibid. p. 56.

158 CRENSHAW, Kimberlé. Mapping the Margins: Intersectionality, Identity Politics, and Violence against Women of Color. p. 1245-1246
} 
Nesse sentido, é imperioso ressaltar: as mulheres negras estão localizadas, em sua maioria, nas classes mais baixas, uma vez que gênero e raça interferem diretamente nas oportunidades de acesso ao mercado de trabalho, que discrimina mulheres, homens negros e, de forma ainda mais aguda, mulheres negras. De fato, são estas últimas que possuem os piores rendimentos no trabalho, as maiores taxas de desemprego e os maiores índices de pobreza degradante ${ }^{159}$. Em 2015, a taxa de desocupação das mulheres negras era de $13,6 \%$, em contraste com os porcentuais de $9,8 \%$ para as mulheres brancas, $8,7 \%$ para os homens negros e $7 \%$ para os homens brancos. No mesmo ano, 49,7\% das mulheres negras ocupadas recebiam, como renda mensal, até um salário mínimo, enquanto $29 \%$ das mulheres brancas, $34,1 \%$ dos homens negros e 17,9\% dos homens brancos encontravam-se na mesma faixa de rendimento ${ }^{160}$.

Deste modo, são extremamente relevantes os efeitos da imbricação entre gênero, raça e classe sobre a experiência da violência. Sem prejuízo de outras formas de constituição e intensificação mútua, podemos concluir que o entrelaçamento entre as opressões por gênero e por raça coloca a mulher negra como a mais provável vítima tanto da violência doméstica quanto da pobreza e da miséria. Por sua vez, a opressão por classe dificulta sobremaneira a saída desta mulher da situação de violência, o que pode ser explicado pela escassez de recursos próprios - materiais e intelectuais, isto é, financeiros e educacionais, sendo que este último interfere não só nas suas oportunidades no interior do competitivo universo do mercado de trabalho, mas em seu acesso, nitidamente prejudicado, a informações sobre seus direitos e garantias enquanto cidadã -, bem como pela menor acessibilidade aos meios institucionais de proteção contra aquela violência, o que, enfim, é reforçado

\footnotetext{
${ }^{159}$ Ibid. p. 49, 58.

${ }^{160}$ IPEA - INSTITUTO DE PESQUISA ECONÔMICA APLICADA. Retrato das desigualdades de gênero e raça. Brasília: Ipea, 2015. Disponível em: http://www.ipea.gov.br/retrato/.
} 
pelo racismo e sexismo institucionais, a seguir exemplificados por Tânia Almeida e Bruna Pereira:

A violência institucional em um país com tamanha expressão de discriminação racial emoldura essa problemática, mesmo que a Lei Maria da Penha se volte para a totalidade das mulheres brasileiras. É verdade que os maus atendimentos e as revitimizações têm sido relatados com frequência pelas mulheres em geral, quando buscam os órgãos públicos para protegê-las e combater a violência em que se encontram. A pressão de agentes públicos para privatizar o crime de violência contra elas, tornando-o menos relevante aos olhos da sociedade e do poder público tem sido uma constante, o que se evidencia, muitas vezes, sob a forma de violência institucional. Embora não se tenha dados apreendidos sobre a cor das mulheres que mais estão a ela submetidas, não é difícil supor que as pretas e pardas são acolhidas com menos atenção e menor credibilidade. Tornar legítimo o reconhecimento delas como sujeito de direitos tem sido uma tarefa árdua do feminismo negro e do movimento de mulheres negras ${ }^{161}$.

Considerando todo o exposto acima, no tópico seguinte, analisaremos os limites da Lei Maria da Penha e do crime de feminicídio no que toca à prevenção e coibição da violência doméstica e familiar contra as mulheres negras.

\subsection{A Lei Maria da Penha, o crime de feminicídio e suas limitações}

O ponto de partida de nossa análise será a Lei 9.099/1995, que criou os Juizados Especiais Criminais, órgãos da Justiça Ordinária que teriam competência para processar, julgar e executar as contravenções penais e os crimes de menor potencial ofensivo, ou seja, cuja pena máxima fosse menor ou igual a 2 (dois) anos ${ }^{162}$. Sua importância para o presente trabalho se dá devido ao fato de que, por ampliar o acesso de causas menores ao Judiciário, esta Lei contribuiu muito para a judicialização da violência doméstica contra as mulheres, que normalmente não conseguiam levar suas queixas para além da

\footnotetext{
${ }^{161}$ ALMEIDA, Tânia Mara Campos de; PEREIRA, Bruna Cristina Jaquetto. Op. cit., p. 56-57.

162 Inicialmente, a pena máxima não poderia ser superior a 1 (um) ano. A Lei 11.313/2006, porém, alterou o art. 61 da Lei 9.099/95, ampliando a competência dos Jecrims.
} 
esfera policial ${ }^{163}$. Com efeito, segundo pesquisas realizadas entre 2001 e 2003, $68,2 \%$ dos conflitos nos Jecrims eram familiares ${ }^{164}$, o que revelou uma forte demanda da sociedade por mecanismos institucionais que refreassem aquele tipo de violência, demanda esta involuntariamente atendida pelos Jecrims.

Não obstante, exatamente porque não foram criados para solucionar este gravíssimo problema social, os Jecrims não foram capazes de abordar o fenômeno da violência doméstica e familiar de forma satisfatória. O procedimento utilizado não se diferenciava daquele empregado na resolução dos delitos comuns, ou seja, focava na transação penal com o Ministério Público, o que, na enorme maioria dos casos, conduzia ao pagamento, pelo agressor, de cestas básicas a terceiros estranhos ao conflito, deixando a vítima completamente desamparada. No âmbito dos Jecrims, não havia uma preocupação com a natureza específica da violência doméstica e familiar, cuja característica mais notória é o conflito continuado e potencialmente cada vez mais grave ${ }^{165}$.

É interessante notar que, apesar de os Jecrims não atenderem às necessidades das mulheres de um modo geral, as razões para esse descontentamento com a prestação jurisdicional variavam bastante de acordo com a classe social na qual a mulher estava inserida. As referidas entrevistas realizadas entre os anos de 2001 e $2003^{166}$ evidenciaram que, enquanto mulheres de classe média almejavam a aplicação de penas mais duras, capazes de efetivamente desestimular a prática da violência, as que se encontravam nas classes mais baixas temiam a prisão de seus parceiros - possível em caso de descumprimento do acordo firmado na transação penal -, pois não podiam arcar com o ônus da perda da renda proveniente de seus empregos. Além disso,

\footnotetext{
${ }^{163}$ AMORIM, Maria Stella de. Acesso à justiça e administração judicial da violência contra a mulher brasileira: políticas de despenalização e de penalização. Anais do XIII Congresso da Anpedi. p. 5. Disponível em:

www.publicadireito.com.br/conpedi/manaus/arquivos/anais/campos/maria_stella_de_amorim.pdf.

${ }^{164}$ Ibid. p. 7.

${ }^{165}$ Ibid. p. 6-7.

${ }^{166}$ Ibid. p. 7-8.
} 
o pagamento de cestas básicas por aqueles constituía verdadeira ameaça à subsistência de suas famílias e de seus filhos, o que levava muitas delas a desistirem da ação judicial, em prejuízo de sua integridade física e psíquica.

Diante do cenário acima retratado e considerando a urgência de serem tomadas medidas preventivas e protetivas em favor de mulheres vítimas de violência doméstica e familiar, em 2006, foi promulgada a Lei 11.340, apelidada Lei Maria da Penha em homenagem à bioquímica nordestina Maria da Penha Maia Fernandes, vítima de duas tentativas de homicídio pelo exmarido em 1983, uma delas responsável por deixá-la paraplégica. Em 2002, depois de anos de omissão do Judiciário e somente após o caso ser levado à Comissão Interamericana de Direitos Humanos, que condenou o Estado Brasileiro por sua inércia e tolerância em relação à agressão, o processo judicial foi encerrado, com a consequente prisão do ex-marido em 2003.

Fruto dos esforços da militância feminista, bem como do engajamento político dos mais variados setores da sociedade, a Lei Maria da Penha foi e vem sendo aclamada - inclusive no âmbito internacional - por seu conteúdo inovador. Por certo, a Lei 11.340/06 é uma grande conquista, na medida em que $(i)$ aborda a violência doméstica e familiar contra a mulher com a devida seriedade, buscando desnaturalizá-la, além de desmistificar a dicotomia entre as esferas pública e privada, na qual esta última seria entendida como o espaço do apolítico e da autonomia privada, não comportando, assim, qualquer intervenção estatal; (ii) oferece um poderoso aporte teórico, conceitual e jurídico sobre o tema, com forte conteúdo educativo; e (iii) mobiliza diversos órgãos públicos e setores da sociedade civil para o devido enfrentamento desta forma de violência, reconhecendo a importância de um enfoque multidisciplinar e intersetorial no tratamento do problema.

Nesta linha, a Lei Maria da Penha: estabelece o compromisso do poder público com políticas de prevenção e combate a todas as formas de violência contra a mulher no âmbito das relações domésticas e familiares (art. $3^{\circ}, \S 1^{\circ}$ ) e, 
para tanto, estipula diretrizes que irão reger esta atuação (art. $8^{\circ}$ ); distingue e conceitua, dentre as várias formas de violência doméstica e familiar contra a mulher, as violências física (art. $7^{\circ}, \mathrm{I}$ ), psicológica (art. $7^{\circ}, \mathrm{II}$ ), sexual (art. $7^{\circ}$, III), patrimonial (art. $7^{\circ}$, IV) e moral (art. $7^{\circ}, \mathrm{V}$ ); proíbe a aplicação da Lei 9.099/95 aos crimes praticados com violência doméstica e familiar contra a mulher, independentemente da pena prevista (art. 41); veda a aplicação de penas de cesta básica ou outras de prestação pecuniária, bem como a substituição de pena que implique exclusivamente o pagamento de multa (art. 17); determina a criação dos Juizados de Violência Doméstica e Familiar contra a Mulher (JVDFM), com competência cível e criminal para processar, julgar e executar as causas relacionadas a este tipo de violência (art. 14); prevê a aplicação de medidas protetivas de urgência dirigidas ao agressor (art. 22) e à vítima (art. 23); garante às mulheres em situação de violência doméstica e familiar o acesso aos serviços da Defensoria Pública (art. 28); e por fim, permite que os JVDFM sejam assessorados por uma equipe de atendimento multidisciplinar, composta por profissionais especializados nas áreas psicossocial, jurídica e de saúde (arts. 29 e 30).

Contudo, a referida Lei nem sempre atenta para a diversidade das experiências de vida de mulheres diferentemente localizadas e, por isso, não oferece mecanismos suficientes capazes de lidar de forma adequada com as especificidades de cada uma dessas realidades, frequentemente silenciadas. Um bom exemplo disso é a invisibilidade das dinâmicas racistas que atravessam o horizonte da violência doméstica contra a mulher, o que torna a própria violência indetectável em alguns contextos, além de prejudicar a eficácia das estratégias de enfrentamento, como no caso de grupos de reflexão e programas de recuperação e reeducação que não se preocupam em orientar os agressores quanto às questões raciais envolvidas.

Ademais, como bem demonstra Ana Luiza Flauzina, o viés punitivista da Lei - acentuado na prática pela dificuldade de implementação de todas as 
suas diretrizes e normas, sobretudo aquelas voltadas para a prevenção da violência e para a proteção da vítima - só se sustenta enquanto tiver a "branquitude como parâmetro"167. Por certo, busca-se solucionar o sexismo do sistema de justiça criminal e toda a inefetividade que ele acarreta por meio do racismo profundamente arraigado neste mesmo sistema, o que, por consequência, vulnerabiliza ainda mais as mulheres negras. Pois é inegável que a perspectiva punitivista do sistema penal brasileiro, adotada pela Lei Maria da Penha e potencializada no cotidiano do Judiciário, apoia-se no racismo e na desvalorização de corpos negros, tidos como descartáveis, dispensáveis:

Nesse tocante, é oportuno sublinhar que no apetite por "carne de segunda" para as fileiras do cárcere, da tortura, da morte, são as pessoas negras, homens e mulheres, meninos e meninas, indubitavelmente as mais afetadas na movimentação de um sistema que tem o racismo como categoria fundante. A consolidação do que, para muitos, é considerado como um movimento genocida na direção da população negra no Brasil tem o controle das mulheres como pilar fundamental ${ }^{168}$.

Neste cenário, a mulher negra é duplamente vitimada: ela é alvo do encarceramento em massa da população negra e a base na qual o sistema de justiça criminal se ampara, já que é a "sua exploração sexual, emocional e financeira" 169 que torna possível o encarceramento masculino. Voltaremos neste assunto mais adiante. Por ora, é suficiente ressaltar, ainda que de modo superficial, os perigos do punitivismo como modelo de justiça penal.

No que tange à Lei Maria da Penha, convém sublinhar que sua rigidez com relação à punição do agressor é realçada quando a violência atinge mulheres negras, já que, neste caso, o punitivismo se coloca como única estratégia de coibição possível. Isso porque, como vimos no segundo capítulo, os conflitos na zona do não ser são primordialmente resolvidos por meio da violência e da expropriação, ante o restrito acesso aos mecanismos legais e institucionais disponíveis na zona do ser. Por essa razão, há uma dificuldade

\footnotetext{
${ }^{167}$ FLAUZINA, Ana Luiza Pinheiro. Lei Maria da Penha: entre os anseios da resistência e as posturas da militância. In: FLAUZINA, Ana; FREITAS, Felipe; VIEIRA, Hector; PIRES, Thula. Discursos negros: legislação penal, política criminal e racismo. Brasília: Brado Negro, 2015. p. 138.

168 Ibid. p. 138.

${ }^{169}$ Ibid. p. 139.
} 
muito maior em implementar, no âmbito daquela zona, as medidas preventivas e protetivas dirigidas à vítima e ao agressor, e que poderiam, se devidamente aplicadas, enfrentar a violência doméstica e familiar contra a mulher de forma extremamente eficiente. No entanto, esta resposta jurídica promissora está muito distante, por exemplo, da realidade das favelas, espaços marcados pela ausência do Estado - ou por sua presença violadora - e pela consequente deficiência na fiscalização do cumprimento daquelas medidas. Na zona do não ser, portanto, a faceta punitivista da Lei Maria da Penha é a única "garantia" oferecida à vítima, o que, em regra, vai de encontro aos seus interesses.

Vejamos um exemplo no qual a inflexibilidade com relação à punição do agressor acaba prejudicando a escuta da vítima, sobretudo quando esta é negra e pobre. Quando a aludida Lei foi promulgada, havia uma enorme preocupação em se evitar a impunidade, chancelada, anteriormente, pelo modelo conciliatório da Lei 9.099/95 ${ }^{170}$. Isso porque muitos dos delitos que se enquadram na violência doméstica e familiar contra a mulher, à época, só podiam ser processados mediante ação penal pública condicionada à representação da vítima. Ocorre que muitas mulheres eram coagidas por seus agressores, com quem mantinham relações íntimas de afeto, a renunciar à representação, o que impossibilitava a continuidade da ação penal. Esta situação era ainda agravada pelo instituto da renúncia tácita: durante todo o procedimento de conciliação, a vítima devia, a cada reunião, exercer seu direito de ratificação da representação. O não comparecimento a uma reunião implicava, automaticamente, o arquivamento do processo por renúncia tácita à representação.

Para garantir a autonomia da manifestação da vontade da mulher em relação a seu parceiro/marido/namorado, a Lei Maria da Penha, em seu art. 16, e o Supremo Tribunal Federal, no bojo da Ação Direta de

\footnotetext{
${ }^{170}$ Ibid. p. $124-125$.
} 
Inconstitucionalidade $\mathrm{n}^{\circ} 4.424 / \mathrm{DF}^{171}$, optaram por, paradoxalmente, dificultar a ingerência da vítima sobre o processo penal ${ }^{172}$. Com efeito, tal artigo determina que a renúncia à representação só é possível na presença do juiz, em audiência marcada especificamente para este fim e realizada antes do recebimento da denúncia, e desde que ouvido o Ministério Público. Aqui, cabe registrar que a estrutura em muitos sentidos ainda precária da Defensoria Pública vem impedindo que mulheres negras e pobres, principais usuárias da assistência judiciária gratuita, recebam a devida orientação quanto aos seus direitos e, portanto, possam se retratar, ou seja, exercer seu direito de renúncia à representação ${ }^{173}$. Por sua vez, o Supremo Tribunal Federal decidiu, na referida ADI, que todo crime de lesão corporal associado à violência doméstica contra a mulher, independentemente de sua gravidade, seria processado por meio de ação penal pública incondicionada, o que, dito de outro modo, significa que, a partir daquele momento, a representação da vítima seria dispensável nos casos de lesão corporal leve vinculados ao âmbito doméstico.

Todo esse movimento em direção à garantia da persecução penal afasta a participação e o envolvimento das vítimas com o processo. Essa postura punitivista adotada pela Lei Maria da Penha é um reflexo do pensamento da militância feminista (branca), que acredita que a eficiência do sistema de justiça criminal se confunde com punição, de preferência, por meio do encarceramento ${ }^{174}$. Este posicionamento é compreensível, já que pode ser interpretado como uma inflexível resposta à terrível indiferença, tolerância e naturalidade com que a violência doméstica contra a mulher vem sendo tratada ao longo das últimas décadas. Ocorre que esta lógica contrasta fortemente com

${ }^{171}$ STF, ADI no 4.424/DF, Rel. Ministro Marco Aurélio, Brasília, 9 fev. 2012. Disponível em: http://redir.stf.jus.br/paginadorpub/paginador.jsp?docTP=TP\&docID=6393143.

${ }^{172}$ FLAUZINA, Ana Luiza Pinheiro. Op. cit., 125, 130.

${ }^{173}$ Ibid. p. 128-129.

${ }^{174}$ Ibid. p. 130. 
a realidade e os interesses das mulheres que resistem no cotidiano a esta forma de violência ${ }^{175}$.

Em pesquisa realizada pelo IPEA, publicada em $2015^{176}$, foi constatado que $80 \%$ das mulheres vítimas de violência doméstica que procuravam a ajuda da justiça não consideravam a prisão de seu agressor - com quem mantinham relações domésticas, familiares ou íntimas de afeto - como uma solução satisfatória para seu problema. Este dado pode ser interpretado à luz das percepções de Maria Stella de Amorim a respeito da efetividade das soluções encontradas para a violência doméstica no âmbito dos Juizados Especiais Criminais ${ }^{177}$. Já naquela época, a autora percebeu que mulheres das classes mais baixas - a maioria delas, provavelmente, negras, tendo em vista a profunda desigualdade racial no Brasil - temiam eventuais imposições de penas privativas de liberdade contra seus parceiros e, em alguns casos, inclusive renunciavam à representação, pois a prisão de seus maridos ou companheiros significava a perda de uma renda essencial para suas famílias.

Vê-se, então, que o punitivismo da Lei Maria da Penha, para além de seu papel simbólico na formação de um pensamento que não admite, em nenhuma hipótese, a banalização da violência contra a mulher, oculta, em seu interior, um olhar insensível aos interesses e necessidades de mulheres negras e/ou pobres, que desejam, primordialmente, a suspensão das agressões e a responsabilização do autor na medida do possível, tendo em vista os laços familiares e de afeto entre vítima e agressor: "a justiça da resistência quotidiana está, portanto, atrelada a uma questão familiar, que considere no seu cômputo o agressor como alguém com quem as vítimas, em sua grande maioria, se importam" 178 .

\footnotetext{
175 Ibid. p. 130-131.

176 VIOLÊNCIA contra a mulher e as práticas institucionais. Ministério da Justiça, Secretaria de Assuntos Legislativos. Brasília: IPEA, 2015 [Série pensando o Direito, n. 52], p. 77.

177 AMORIM, Maria Stella de. Op. cit., p. 7.

${ }^{178}$ FLAUZINA, Ana Luiza Pinheiro. Op. cit., p. 131.
} 
Uma resposta interessante para essas demandas, plausível nos casos menos graves, é a suspensão condicional do processo ${ }^{179}$ atrelada à exigência de que o réu se submeta, por no mínimo dois anos, aos trabalhos da equipe multidisciplinar, por meio de um acompanhamento psicológico e/ou de uma participação em grupos de reflexão. Este procedimento vem sendo adotado com muito sucesso em alguns locais, como no Distrito Federal ${ }^{180}$. Dentre suas vantagens, destacam-se: uma maior colaboração por parte da vítima, que vê seus interesses sendo atendidos; uma responsabilização mais rápida e mais efetiva do agressor, evitando-se, com isso, o risco da prescrição; a prevenção de novas violências, em decorrência do monitoramento proporcionado pelo aparato multidisciplinar; e um maior acesso à Justiça, já que a vítima pode contatá-la "de forma ágil e desburocratizada"181 a qualquer momento durante a suspensão do processo. No entanto, por mais atraente que esta solução seja para as mulheres em situação de violência, ela não é vista com bons olhos pela militância feminista e por todos aqueles que priorizam a punição do agressor.

Este punitivismo é ainda agravado pela prática judiciária, que nem sempre observa todas as possibilidades oferecidas pela Lei 11.340/06 e, em algumas situações, descumpre frontalmente suas diretrizes e normas. Este é o caso dos frequentes desmembramentos ${ }^{182}$ das prestações jurisdicionais cíveis e criminais, o que se tornou a regra no âmbito dos Juizados de Violência Doméstica e Familiar contra a Mulher (JVDFM), que declinam sua competência cível em favor das Varas de Família, muito embora a Lei Maria da Penha tenha afirmado expressamente, em seu artigo 14, a competência híbrida daqueles.

\footnotetext{
179 Ibid. p. 132-135

180 ASPER Y VALDÉS, Luciana; BARRETO, Fabiana Costa Oliveira; MORATO, Alessandra Campos; PELEGRINI, Juliana Vieira. Lei Maria da Penha, ciclo da violência e a suspensão condicional do processo: percepções da prática experimentada no Distrito Federal. Revista do MPDFT, v. 1, n. 5, p. 101-120, 2011.

${ }^{181}$ FLAUZINA, Ana Luiza Pinheiro. Op. cit., p. 134.

182 VIOLÊNCIA contra a mulher e as práticas institucionais. Op. cit., p. 102-103.
} 
Com efeito, a despeito das incontáveis vantagens ${ }^{183}$ ligadas a um tratamento conjunto e integrado de todas as questões jurídicas - cíveis e criminais - relacionadas à coibição da violência doméstica e familiar contra a mulher - a saber, a economia do tempo e do dinheiro da assistida, que não terá que se deslocar entre diferentes varas e defensorias públicas; a melhoria no acesso ao Judiciário, proporcionada não só pelo motivo acima exposto como também pela simplificação de sua estrutura institucional, que se torna mais compreensível para leigos; o conhecimento mais profundo e detalhado, pelo defensor e pelo juiz da JVDFM, da situação particular vivida pela assistida, o que garante uma assistência jurídica e decisões judiciais mais adequadas e bem informadas -, os juízes dos JVDFM vem entendendo que sua competência cível restringe-se a medidas de urgência, o que desvirtua completamente os propósitos e objetivos da Lei Maria da Penha.

Isso porque a unificação dos processos cíveis e criminais em uma mesma vara especializada no combate da violência doméstica e familiar contra a mulher tornaria os instrumentos e instituições jurídicas muito mais efetivos na luta pela erradicação desta forma de violência. Se a competência híbrida dos JVDFM fosse posta em prática, esses Juizados não estariam limitados às soluções penais que, afinal, são as medidas menos visadas pelas assistidas, e em especial, pelas assistidas negras e pobres. $\mathrm{O}$ tratamento independente das questões cíveis - guarda dos filhos menores, dissolução do casamento ou da união estável, partilha de bens, prestação de alimentos, etc. - em varas de família comuns coloca a assistida em uma situação de desamparo, pois toda a preocupação anterior, no âmbito do JVDFM e da defensoria pública vinculada a este Juizado, em conhecer sua realidade familiar de violência continuada é ignorada pelas varas de família e pelos defensores ligados a elas.

Esta separação nas competências, portanto, afasta do Judiciário as assistidas, que têm dificuldades em entender seus confusos trâmites

${ }^{183}$ Ibid. p. 102. 
burocráticos e, além disso, veem seu esforço inicial ser recomeçado do zero nas varas cíveis, espaço institucional que não está preparado para lidar com suas necessidades especiais. Neste contexto, são novamente as mulheres negras e pobres que mais sofrem com esta deficiência na prestação jurisdicional: são elas as que mais buscam soluções não penais, bem como as que mais dependem da assessoria jurídica oferecida pela Defensoria Pública, fragmentada em diversos órgãos, o que significa que a chance de serem assistidas por um único defensor - familiarizado com seu caso particular - em processos que tramitam em varas distintas é extremamente reduzida.

Se, por um lado, a Lei Maria da Penha representa um enorme avanço na luta pela erradicação da violência contra a mulher, merecendo, assim, mais elogios do que críticas, por outro, não há nenhum motivo para comemorar a promulgação da Lei 13.104/2015, que instituiu o feminicídio como homicídio qualificado - art. 121, $\S 2^{\circ}$, VI, CP - e o incluiu no rol de crimes hediondos art. $1^{\circ}$, I, da Lei 8.072/90.

A primeira dificuldade que se coloca à nossa frente diz respeito a qual sujeito a Lei pretende proteger. Segundo o inciso VI do art. $121, \S 2^{\circ}, \mathrm{CP}$, aplica-se a qualificadora quando o homicídio for cometido "contra a mulher por razões da condição de sexo feminino". Vê-se, portanto, que uma interpretação literal do referido inciso pode conduzir à exclusão de mulheres trans e travestis do âmbito de sua proteção, em total afronta aos direitos dessas mulheres, já excessivamente vulnerabilizadas pelo violento sistema cisgênero, heteronormativo e misógino que impera em nossa sociedade. A propósito, é necessário ressaltar que a expectativa de vida de pessoas trans no Brasil é de cerca de 35 anos, menos da metade da expectativa de vida da população em geral. Além disso, é significativo o fato de que " $40 \%$ de todos os assassinatos de pessoas trans registrados no mundo ocorrem em solo brasileiro" ${ }^{184}$. Esses

\footnotetext{
184 Disponível em: http://jcrs.uol.com.br/_conteudo/2016/09/cadernos/jornal_da_lei/522567expectativa-de-vida-trans-e-menos-da-metade-da-media-nacional.html.
} 
dados alarmantes não podem ser ignorados e exigem uma resposta imediata e efetiva do poder público.

De um ponto de vista simbólico, a supressão de mulheres trans e travestis promovida pela Lei 13.104/2015 é inaceitável, na medida em que reproduz e potencializa a incessante marginalização desses corpos, rejeitados de tal forma pela sociedade que nem mesmo seu direito à vida é assegurado. Contudo, essa exclusão se torna menos expressiva se considerarmos a completa inocuidade da Lei, incapaz de produzir qualquer alteração significativa no quadro de homicídios contra mulheres.

Antes de adentrar no tema da ineficácia do punitivismo do crime de feminicídio, é pertinente fazer um esboço do quadro geral de homicídios de mulheres no Brasil, a partir da reunião de algumas estatísticas relevantes. De acordo com o "Mapa da Violência 2015: homicídio de mulheres no Brasil", "as taxas de homicídio de mulheres brancas caíram 11,9\%: de 3,6 por 100 mil brancas, em 2003, para 3,2 em 2013. Em contrapartida, as taxas das mulheres negras cresceram 19,5\%, passando, nesse mesmo período, de 4,5 para 5,4 por 100 mil"185. Isso significa que o índice de vitimização negra, isto é, " $a$ diferença percentual entre as taxas de homicídio de mulheres de ambos os grupos", aumentou expressivamente entre 2003 e 2013, passando de 22,9\% para $66,7 \%{ }^{186}$. Esses dados revelam não só que as mulheres negras são as maiores vítimas de violências fatais, mas que há um contínuo crescimento na desproporção entre as taxas de homicídio de mulheres brancas e negras.

Ademais, a pesquisa demonstra que a violência que mais atinge as mulheres - independentemente da idade - é a doméstica, haja vista que, em $67,2 \%$ dos atendimentos no SUS, as vítimas foram agredidas por parentes próximos - pai, mãe, padrasto, filho ou irmão - ou por parceiros e ex-parceiros

\footnotetext{
185 WAISELFISZ, Julio Jacobo. Mapa da Violência 2015: homicídio de mulheres no Brasil. Brasília: Flacso Brasil, 2015. p. 31. Disponível em: http://www.mapadaviolencia.org.br/pdf2015/MapaViolencia 2015 mulheres.pdf.

186 Ibid. p. 32.
} 
(dados referentes ao ano de 2014) ${ }^{187}$. Acrescente-se que, em 71,9\% dos casos, as agressões se deram na própria residência. Por fim, no que se refere aos homicídios de mulheres registrados pelo SIM (Sistema de Informações sobre Mortalidade) em 2013, 50,3\% foram praticados por alguém da família, e $33,2 \%$ foram cometidos pelo parceiro ou ex-parceiro da vítima ${ }^{188}$, o que significa que, em $83,5 \%$ dos casos, o autor do crime é alguém próximo.

$\mathrm{Na}$ mesma linha, em pesquisa ${ }^{189}$ realizada pelo IPEA a partir de dados corrigidos do SIM, foi apurado que, entre 2009 e 2011, 5.722 mulheres morreram por causas violentas a cada ano ou, dito de outro modo, uma mulher morreu de forma violenta a cada $1 \mathrm{~h} 32 \mathrm{~min}$. Dentre as vítimas, as mais atingidas foram mulheres negras - que corresponderam a $60,9 \%$ do número total de vitimadas -, entre 20 e 39 anos - 53,1\% do total encontravam-se nessa faixa etária - e de baixa escolaridade - 47,1\% das vítimas maiores de 15 anos possuíam menos de oito anos de estudo, em contraste com os $22,1 \%$ que possuíam oito anos ou mais de estudo. Mais uma vez, as estatísticas demonstram que, para além da ordem de gênero, também as dimensões de raça e de classe são extremamente relevantes para a compreensão do contexto no qual se dá a violência.

Quanto aos locais onde ocorreram os óbitos, vale registrar que 27,6\% deram-se no interior dos domicílios, o que revela a íntima relação entre esses homicídios e a violência doméstica e familiar contra a mulher. Nesse sentido, as mortes que ocorreram em hospitais ou em outros estabelecimentos de saúde - 28,3\% - e as que aconteceram em vias públicas - 30,1\% - não refutam esta realidade, visto que muitos parceiros agridem e, em alguns casos, assassinam

\footnotetext{
${ }^{187}$ Ibid. p. 48.

188 Ibid. p. 70.

189 GARCIA, Leila Posenato; FREITAS, Lucia Rolim Santana de; SILVA, Gabriela Drummond Marques da; HÖFELMANN, Doroteia Aparecida. Estimativas corrigidas de feminicídios no Brasil, 2009 a 2011. Rev Panam Salud Publica, n. 37, p. 251-257, 2015.
} 
suas parceiras em locais públicos ${ }^{190}$, assim como muitas mulheres são socorridas e levadas ao hospital antes de falecerem.

Por todo o exposto, pode-se dizer que há uma evidente correlação entre os homicídios que atingem mulheres e a violência doméstica e familiar contra as mesmas. Dessa forma, não há como negar que a raiz do problema dos feminicídios está no sexismo - no controle abusivo dos corpos e das mentes das mulheres, na sua constante inferiorização e subordinação e no poder disciplinador, que se concretiza muitas vezes por meio da violência, seu instrumento mais eficaz - e não no apenamento do crime que, aliás, nunca foi leve. Com efeito, quanto mais se acredita no poder de persuasão de penas mais duras, mais frustrantes serão os resultados das estatísticas. Se um tempo maior de pena produz alguma consequência, esta seria o reforço do machismo desses homens, reclusos em um ambiente historicamente sexista ${ }^{191}$.

Por fim, devemos nos perguntar: o que significa apostar em um maior encarceramento? Convém lembrar que o sistema prisional racista e sexista se apoia - e solta todo o seu peso - nas mulheres negras para que $o$ encarceramento massivo de homens negros seja minimamente sustentável. De fato, o Estado não é capaz - ou não tem interesse - de carregar esse fardo sozinho, e exige e espera que aquelas mulheres partilhem essa responsabilidade. Pela ótica financeira, são elas que, na sua solidão, assumem o papel de provedoras não só de suas famílias, mas também dos próprios apenados, sejam eles seus companheiros, filhos ou irmãos. Sobre esse aspecto, frise-se que em nenhum momento este ônus recai exclusivamente sobre o poder público. Decerto, as condições degradantes e desumanas das prisões são,

\footnotetext{
${ }^{190}$ De acordo com a pesquisa, "estudo realizado nos Estados Unidos demonstrou associação positiva entre a mulher sair à noite e a ocorrência de agressão pelo parceiro”. Ibid. p. 254.

${ }^{191}$ FLAUZINA, Ana Luiza Pinheiro. O feminicídio e os embates das trincheiras feministas. Discursos Sediciosos, n. 23/24, 2016, p. 97-98.
} 
por si só, um indicativo das incontáveis carências materiais que afetam o dia-adia dos presos, supridas, em grande medida, por essas mulheres ${ }^{192}$.

Além de seu dinheiro, seus corpos estão à disposição para atender às necessidades físicas e emocionais desses homens. Sem dúvida, a exploração sexual das mulheres negras é um poderoso mecanismo de controle e recompensa com o qual o Estado conta para garantir a ordem nas prisões, e sem o qual não seria possível esperar qualquer cooperação por parte dos apenados que, em meio àquele ambiente brutal e deplorável, não teriam nada a perder com a desobediência, instaurando-se, assim, um caos administrativo ${ }^{193}$. Entretanto, sua exploração sexual não se resume a esta função disciplinadora. Nesse sentido, a revista de seus corpos é marcada pelo abuso e pelo desrespeito, os quais estão em perfeita consonância com o valor atribuído pelos policiais a essas mulheres, destituídas dos traços "honrados" da feminilidade branca:

A revista vexatória invade as cavidades de mulheres que não são detentoras de seus próprios corpos. Atualizando a ordem escravista, seu corpo e sua sexualidade não são tutelados por qualquer tipo de valor moral associada à ideia de feminilidade. $\mathrm{O}$ recato e a pureza, que aprisionam o ideal feminino branco, são abandonados pela violação explícita, a disponibilidade e o livre acesso atrelado aos corpos negros. Nas filas das visitas, vê-se uma horda de mulheres "escuras", jovens, idosas, que devem ser revistadas não só pela possibilidade de carregarem objetos proibidos para dentro dos portões. A suspeição justifica a imposição de uma pena autônoma: o abuso sexual legitimado como forma de marcar sua vulnerabilidade, como uma maneira de simbolicamente submetê-las a um regime de constrangimento talhado para seus corpos. (...). A punição dos homens prevê, assim, uma punição complementar às mulheres, condenadas pelo delito de serem a eles conectados, de fazerem parte da mesma comunidade abjeta situada nos contornos da negritude ${ }^{194}$.

A esse respeito, o depoimento de Cremilda, mãe de um ex-detento, é elucidativo:

Eu vi muita coisa ruim. Uma senhora bem velhinha, magrinha, foi obrigada a ficar nua também. Tímida, ela tentou cobrir a genitália com as duas mãozinhas. Nossa, teve que ouvir coisas absurdas. A agente disse: 'Você não teve vergonha de usar isso pra fabricar bandido pra encher o saco da gente, agora tem vergonha de mostrar?'.

\footnotetext{
192 Ibid. p. 99.

${ }^{193}$ Ibid. p. 100.

194 Ibid. p. 100
} 
Ela tremia de medo. E eu não podia falar nada, porque, se eu reagisse, sabia que meu filho seria espancado ${ }^{195}$.

A revista vexatória é uma prática institucionalizada nas prisões brasileiras, apesar de ser frontalmente ilegal e inconstitucional. Muitas(os) visitantes não sabem que esta prática viola seus direitos - sobretudo o direito à intimidade, garantido pelo art. $5^{\circ}$, inc. X, da Constituição Federal -, e as(os) que têm acesso a essa informação não se arriscam a questionar, pois podem sofrer represálias, como a proibição de novas visitas ou a tortura/espancamento/violação sexual dos seus parentes. O procedimento de revista padrão pelo qual os familiares - adultos, idosos e até mesmo crianças são obrigados a passar é humilhante e extremamente abusivo, como relata Priscila, que visita seu marido regularmente:

O Estado faz de tudo pra gente abandonar a nossa família. Fazem a gente abaixar, peladas, três vezes de frente, três de costas, fazer quadradinho de 8 , de 16 , ficar em frente ao espelho, colocar a mão, abrir, passar o papel. (...) O Estado faz de tudo pra você abandonar seu parente. Mas a gente não abandona. Só quem abre as pernas ali sabe como é. Aquilo é um estupro ${ }^{196}$.

Por tudo isso, podemos concluir que o punitivismo propagado pelo crime de feminicídio tem o propósito exclusivo de alimentar um sistema penal genocida que tem no corpo negro seu alvo mais almejado. Isso porque o "incremento da punição" não tem qualquer efeito sobre a incidência social das práticas delituosas - que permanece inalterada -, e se torna apenas um discurso simbólico que "opera no sentido de legitimar um sistema extremamente violador. Violador não só de homens, mas também de mulheres"197, que assumem a árdua tarefa de garantir um mínimo de dignidade a homens que habitam um espaço marcado pela "experiência de expropriação quase absoluta"198, em detrimento de sua própria integridade física, sexual e psíquica.

\footnotetext{
195 Disponível em: http://www.revistaforum.com.br/2014/04/09/quem-abre-pernas-ali-sabe-como-eaquilo-e-um-estupro/.

196 Ibid.

${ }^{197}$ FLAUZINA, Ana Luiza Pinheiro. Op. cit., p. 101.

198 Ibid. p. 101.
} 


\section{Conclusão}

As reflexões que fizemos ao longo deste trabalho revelam a importância de um olhar atento às imbricadas relações entre as diversas estruturas de poder para uma efetiva compreensão das dinâmicas que atravessam o contexto ou a realidade investigada. No âmbito do Direito, este olhar é indispensável, uma vez que, a elaboração - no Legislativo - e a implementação - no Judiciário e no Executivo - de soluções jurídicas adequadas e eficazes pressupõem um profundo entendimento do problema, considerado em toda a sua complexidade. Dessa forma, quando o Direito tenta corrigir desigualdades a partir de um olhar míope que não enxerga o entrecruzamento entre os múltiplos sistemas de opressão, ele produz remédios jurídicos não apenas inócuos, mas também potencializadores dessas ou de outras desigualdades, o que foi demonstrado a partir do exame das insuficiências e perigos presentes nas Leis 11.340/2006 e 13.104/2015 - sem dúvida, em diferentes proporções -, que têm como objetivo a prevenção e o enfrentamento da violência contra a mulher.

É interessante observar, ainda, que análises jurídicas pautadas por um enfoque interseccional desafiam e, possivelmente, transformam a tendência universalizante do Direito, cujas normas se dirigem a um sujeito supostamente universal - que, todavia, é marcado pela branquitude, pela masculinidade, pela heterossexualidade e pelo privilégio de classe -, em tese, capaz de satisfazer qualquer pretensão de generalidade do Direito. Assim, dar voz e visibilidade às experiências concretas de pessoas que ocupam diferentes posições na hierarquia social constantemente produzida e reproduzida pelas articuladas estruturas de dominação pode significar um importante passo em direção ao fim da prevalência do sujeito abstrato na dogmática jurídica.

Por fim, destaque-se que em nenhum momento este trabalho se propôs a exaurir as discussões a respeito das muitas maneiras através das quais os 
indivíduos experimentam suas opressões ou privilégios, que estão interligados. Pelo contrário, seu objetivo é estimular novos diálogos que tenham o compromisso de abordar as incontáveis interações entre as múltiplas estruturas de poder - exemplificadas pelas discriminações por gênero, raça, etnia, classe social, idade, casta, religião, origem nacional, deficiência e orientação sexual bem como as vulnerabilizações produzidas por essas imbricações nas diversas esferas da vida protegidas pelo Direito - saúde, educação, trabalho, moradia, segurança, mobilidade urbana, lazer, consumo, liberdade, propriedade, família, etc. Portanto, em que pese este trabalho ser voltado para as experiências de mulheres negras em situação de violência, com ênfase para a importância da racialização do debate acerca da desigualdade de gênero - normalmente pautado por uma branquitude não nomeada -, outras análises que levem em consideração as demais dicotomias hierárquicas e estudem outras áreas de proliferação dessas desigualdades são também imprescindíveis para o pleno empoderamento e emancipação de todos e todas. Afinal, "renunciar categorias é renunciar a condição política de diversos corpos e experiências que por elas são social e politicamente produzida(o)s" ${ }^{\prime 199}$.

199 PIRES, Thula. O que significa renunciar a uma categoria? Disponível em: http://emporiododireito.com.br/o-que-significa-renunciar-a-uma-categoria/. 


\section{Bibliografia}

ALMEIDA, Tânia Mara Campos de; PEREIRA, Bruna Cristina Jaquetto. Violência doméstica e familiar contra mulheres pretas e pardas no Brasil: reflexões pela ótica dos estudos feministas latino-americanos. Crítica $e$ Sociedade: revista de cultura política, v. 2, n. 2, Dossiê: Cultura e Política, p. 42-63, dez. 2012.

ALMENDRA, Javiera Cubillos. La importancia de la interseccionalidad para la investigación feminista. Oxímora Revista Internacional de Ética y Política, $\mathrm{n}^{\mathrm{o}}$ 7, p. 119-137, Otoño 2015.

AMORIM, Maria Stella de. Acesso à justiça e administração judicial da violência contra a mulher brasileira: políticas de despenalização e de penalização. Anais do XIII Congresso da Anpedi. Disponível em: www.publicadireito.com.br/conpedi/manaus/arquivos/anais/campos/maria_stel la_de_amorim.pdf.

ASPER Y VALDÉS, Luciana; BARRETO, Fabiana Costa Oliveira; MORATO, Alessandra Campos; PELEGRINI, Juliana Vieira. Lei Maria da Penha, ciclo da violência e a suspensão condicional do processo: percepções da prática experimentada no Distrito Federal. Revista do MPDFT, v. 1, n. 5, p. 101-120, 2011.

BENTO, Maria Aparecida da Silva. Notas sobre a expressão da branquitude nas instituições. In: BENTO, Maria Aparecida da Silva (Org.). Identidade, branquitude e negritude: contribuições para a psicologia social no Brasil: novos ensaios, relatos de experiência e de pesquisa. São Paulo: Casa do Psicólogo, 2014. p. 13-33.

BERNARDINO-COSTA, Joaze; GROSFOGUEL, Ramón. Decolonialidade e perspectiva negra. Soc. estado, Brasília, v. 31, n. 1, p. 15-24, abr. 2016. 
BUTLER, Judith. Excitable speech: a politics of the performative. Nova York: Routledge, 1997. 185 p.

BUTLER, Judith. Problemas de gênero: feminismo e subversão da identidade. $11^{\mathrm{a}}$ ed.. Rio de Janeiro: Civilização Brasileira, 2016.

CARDOSO, Cláudia Pons. Amefricanizando o feminismo: o pensamento de Lélia Gonzalez. Estudos Feministas, Florianópolis, v. 22, n. 3, p. 965-986, jan. 2015.

CARDOSO, Lourenço. O branco-objeto: o movimento negro situando a branquitude. Instrumento: R. Est. Pesq. Educ. Juiz de Fora, v. 13, n. 1, p. 8193, jan./jun. 2011.

CARNEIRO, Sueli. Enegrecer o feminismo: a situação da mulher negra na América Latina a partir de uma perspectiva de gênero. In: Racismos Contemporâneos, Rio de Janeiro: Takano Editores, 2003.

CASTRO-GÓMEZ, Santiago; GROSFOGUEL, Ramón. Giro decolonial, teoría crítica y pensamiento heterárquico. In: CASTRO-GÓMEZ, Santiago; GROSFOGUEL, Ramón (Org.). El giro decolonial: reflexiones para una diversidad epistémica más allá del capitalismo global. Bogotá: Siglo del Hombre Editores, 2007. p. 9-23.

CRENSHAW, Kimberlé. Mapping the Margins: Intersectionality, Identity Politics, and Violence against Women of Color. Stanford Law Review, vol. 43, n. 6, p. 1241-1299, jul. 2010.

CRENSHAW, Kimberlé. Documento para o encontro de especialistas em aspectos da discriminação racial relativos ao gênero. Estudos Feministas, vol. 10, núm. 1, p. 171-188, jan. 2002.

CURIEL, Ochy. De las identidades a la imbricación de las opresiones: desde la experiencia. In: FLAUZINA, Ana; PIRES, Thula (Org.). Encrespando - Anais do I Seminário Internacional: Refletindo a Década Internacional dos Afrodescendentes (ONU, 2015-2024). Brasília: Brado Negro, 2016. p. 75-89. 
CURIEL, Ochy. Género, raza y sexualidad, debates contemporáneos. Disponível em http://www.urosario.edu.co/urosario_files/1f/1f1d1951-0f7e43ff-819f-dd05e5fed03c.pdf.

DAVIS, Angela. Mulheres, raça e classe. São Paulo: Boitempo, 2016. 244 p.

FLAUZINA, Ana Luiza Pinheiro. Lei Maria da Penha: entre os anseios da resistência e as posturas da militância. In: FLAUZINA, Ana; FREITAS, Felipe; VIEIRA, Hector; PIRES, Thula. Discursos negros: legislação penal, política criminal e racismo. Brasília: Brado Negro, 2015. p. 115-144.

FLAUZINA, Ana Luiza Pinheiro. O feminicídio e os embates das trincheiras feministas. Discursos Sediciosos, n. 23/24, 2016, p. 95-104.

FRANTZ, Fanon. Pele negra, máscaras brancas. Salvador: EDUFBA, 2008. $194 \mathrm{p}$.

GARCIA, Leila Posenato; FREITAS, Lucia Rolim Santana de; SILVA, Gabriela Drummond Marques da; HÖFELMANN, Doroteia Aparecida. Estimativas corrigidas de feminicídios no Brasil, 2009 a 2011. Rev Panam Salud Publica, n. 37, p. 251-257, 2015.

GONZALEZ, Lélia. A categoria político-cultural de amefricanidade. Tempo Brasileiro, Rio de Janeiro, nº 92/93, p. 69-82, jan.jun. 1988.

GONZALEZ, Lélia. Por um feminismo afrolatinoamericano. Revista Isis Internacional, Santiago, v. 9, p. 133-141, 1988b.

GONZALEZ, Lélia. Racismo e sexismo na cultura brasileira. In: SILVA, L. A. et al. Movimentos sociais urbanos, minorias e outros estudos. Ciências Sociais Hoje, Brasília, Anpocs, n. 2, p. 223-244, 1984.

GROSFOGUEL, Ramon. What is Racism? Journal of World-Systems Research, [S.1.], v. 22, n. 1, p. 9-15, mar. 2016.

HALL, Stuart. Quem precisa da identidade? Tradução de Tomaz Tadeu da Silva. In: SILVA, Tomaz Tadeu da (Org.). HALL, Stuart; WOODWARD, Kathryn. Identidade e diferença. A perspectiva dos estudos culturais. Petrópolis: Editora Vozes, [1996] 2000. p. 103-133. 
HARAWAY, Donna. Saberes localizados: a questão da ciência para o feminismo e o privilégio da perspectiva parcial. Cadernos Pagu, Campinas, n. 5, p. 7-41, jan. 2009.

hooks, bell. Ain't I a Woman: Black Women and Feminism. London: Pluto Press, 1982. 205 p.

IPEA - INSTITUTO DE PESQUISA ECONÔMICA APLICADA. Retrato das desigualdades de gênero e raça. Brasília: Ipea, 2015. Disponível em: http://www.ipea.gov.br/retrato.

JESUS, Diego Santos Vieira de. Mundo macho: homens, masculinidades e relações internacionais. Revista Brasileira de Estudos Políticos, Belo Horizonte, n. 109, p. 309-364, jul./dez. 2014.

L. MOORE, Henrietta. Fantasias de poder e fantasias de identidade: gênero, raça e violência. Cadernos Pagu, Campina s, n. 14, p. 13-44, jun. 2015. LONGO, Ivan. "Só quem abre as pernas ali sabe como é. Aquilo é um estupro". Disponível em: http://www.revistaforum.com.br/2014/04/09/quemabre-pernas-ali-sabe-como-e-aquilo-e-um-estupro/. Acesso em 30 mai. 2017.

LUGONES, María. Rumo a um feminismo descolonial. Estudos Feministas, Florianópolis, v. 22, n. 3, p. 935-952, jan. 2015.

MEMMI, Albert. Retrato do colonizado precedido de Retrato do colonizador. Rio de Janeiro: Civilização Brasileira, 2007. 190 p.

MIGNOLO, Walter. La idea de América Latina (la derecha, la izquierda y la opción decolonial). Crítica y Emancipación, (2): p. 251-276, primer semestre 2009.

OLIVEIRA, Adriana Vidal de. Constituição e direitos das mulheres: uma análise dos estereótipos de gênero na Assembleia Constituinte e suas consequências no texto constitucional. Curitiba: Juruá, 2015. 474 p.

OYĚWÙMÍ, Oyèrónké. Conceituando o gênero: os fundamentos eurocêntricos dos conceitos feministas e o desafio das epistemologias africanas. Tradução para uso didático de: OYĚWÙMÍ, Oyèrónké. Conceptualizing Gender: The 
Eurocentric Foundations of Feminist Concepts and the challenge of African Epistemologies. African Gender Scholarship: Concepts, Methodologies and Paradigms. CODESRIA Gender Series. Volume 1, Dakar, CODESRIA, 2004, p. 1-8, por Juliana Araújo Lopes.

OYĚWÙMÍ, Oyèrónké. Family bonds/Conceptual Binds: African notes on Feminist Epistemologies. Signs, Vol. 25, No 4, Feminisms at a Millennium (Summer, 2000), p. 1093-1098. Tradução para uso didático por Aline Matos da Rocha.

PEREIRA, Bruna Cristina Jaquetto. Tramas e dramas de gênero e de cor: a violência doméstica e familiar contra mulheres negras. Brasília: Brado Negro, 2016. 200 p.

PINHO, Osmundo de Araújo. O efeito do sexo: políticas de raça, gênero e miscigenação. Cadernos pagu, Campinas, n. 23, p. 89-119, julho-dezembro de 2004.

PIRES, Thula. O que significa renunciar a uma categoria? Disponível em: http://emporiododireito.com.br/o-que-significa-renunciar-a-uma-categoria/. Acesso em 2 jun. 2017.

QUIJANO, Aníbal. Colonialidade do poder, eurocentrismo e América Latina. In: LANDER, Edgardo (Org.). A colonialidade do saber: eurocentrismo e ciências sociais. Buenos Aires: Conselho Latino-americano de Ciências Sociais - CLACSO, 2005. p. 107-130.

RAMOS, Alberto Guerreiro. Introdução crítica à sociologia brasileira. Rio de Janeiro: Editora UFRJ, 1995. 292 p.

SOUZA, Neusa Santos. Tornar-se negro ou as vicissitudes da identidade do negro brasileiro em ascensão social. $2^{\mathrm{a}}$ ed.. Rio de Janeiro: Edições Graal, 1983. $88 \mathrm{p}$.

STF, ADI no 4.424/DF, Rel. Ministro Marco Aurélio, Brasília, 9 fev. 2012: http://redir.stf.jus.br/paginadorpub/paginador.jsp?docTP=TP\&docID=639314. 
STRUCHINER, Noel. O direito como um campo de escolhas: por uma leitura das regras como relações. In: RODRIGUEZ, José Rodrigo; COSTA, Carlos Eduardo Batalha da Silva e; BARBOSA, Samuel Rodrigues (Org). Nas fronteiras do formalismo: a função social da dogmática jurídica hoje. São Paulo: Saraiva, 2010. p. 103-127.

VIOLÊNCIA contra a mulher e as práticas institucionais. Ministério da Justiça, Secretaria de Assuntos Legislativos. Brasília: IPEA, 2015 [Série pensando o Direito, n. 52]. 109 p.

WAISELFISZ, Julio Jacobo. Mapa da Violência 2015: homicídio de mulheres no Brasil. Brasília: Flacso Brasil, 2015. 79 p. Disponível em: http://www.mapadaviolencia.org.br/pdf2015/MapaViolencia_2015 mulheres.p df. 